Cristiano de Salles Almeida

\title{
Distribuição espacial da biomassa microfitobentônica no perfil batimétrico da região de Ubatuba, SP
}

\begin{abstract}
Dissertação apresentada ao Instituto Oceanográfico da Universidade de São Paulo, como parte dos requisitos para obtenção do título de Mestre em Ciências, Programa de Oceanografia, área de Oceanografia Biológica.
\end{abstract}

Orientadora: Prof $\stackrel{a}{\text {. Dra }}$. Eduinetty Ceci Pereira Moreira de Sousa 


\section{Universidade de São Paulo}

Instituto Oceanográfico

Distribuição espacial da biomassa microfitobentônica no perfil batimétrico da região de Ubatuba, SP

Cristiano de Salles Almeida

VERSÃO CORRIGIDA

Dissertação apresentada ao Instituto Oceanográfico da Universidade de São Paulo, como parte dos requisitos para obtenção do título de Mestre em Ciências, área de Oceanografia Biológica.

Julgada em 26/06/2014

Prof ${ }^{\mathrm{a}}$. Dr ${ }^{\mathrm{a}}$. Eduinetty Ceci Pereira Moreira de Sousa

Conceito

Prof ${ }^{a}$. Dr ${ }^{\mathrm{a}}$. Thais Navajas Corbisier

Conceito

Prof ${ }^{a}$. Dr ${ }^{\mathrm{a}}$. Antonia Cecilia Zacagnini Amaral

Conceito 
Às pessoas que eu mais amo, meus pais Tarcisio e Eunice. 
"Quando as pessoas entenderem umas às outras;

Quando as pessoas respeitarem umas às outras;

E quando as pessoas amarem umas às outras;

Então haverá um dia em que a verdadeira paz poderá reinar sobre a Terra". (Cristiano de Salles Almeida, 2010) 


\section{SUMÁRIO}

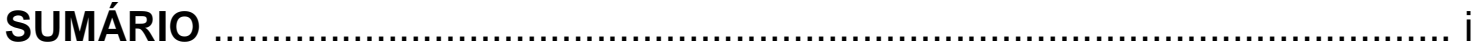

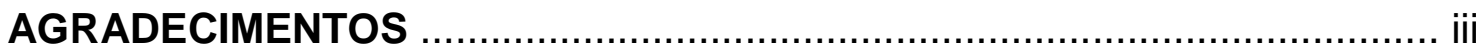

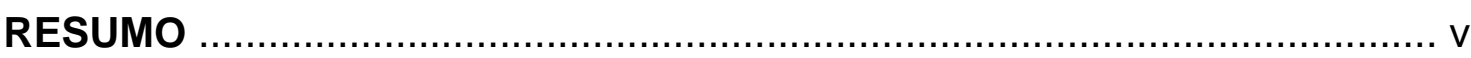

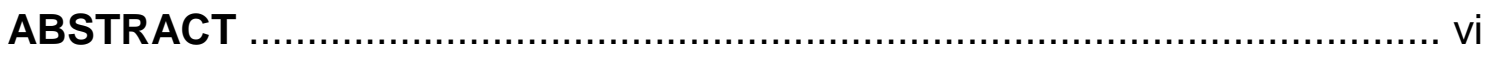

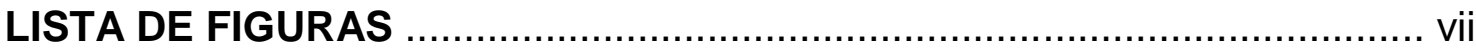

LISTA DE TABELAS ........................................................................... ix

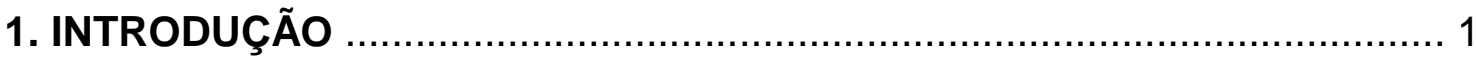

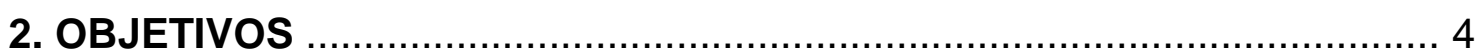

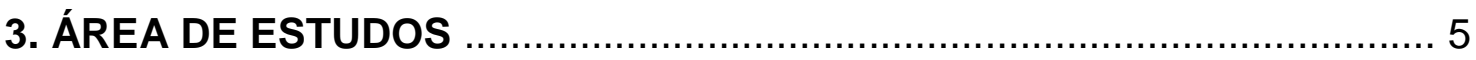

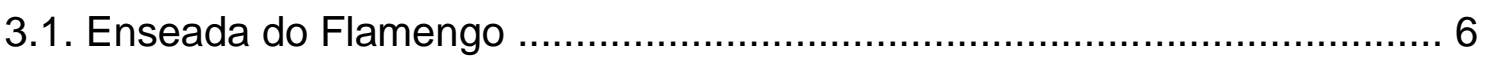

3.2. Enseada da Fortaleza .......................................................................... 7

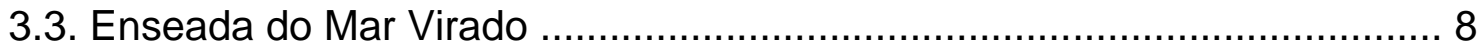

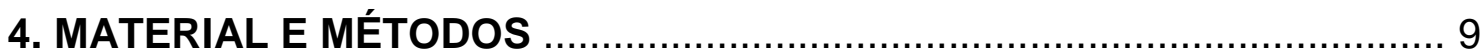

4.1. Procedimentos de amostragem do microfitobentos .............................. 9

4.2. Extração dos pigmentos ............................................................. 12

4.3. Avaliação espectrofotométrica dos pigmentos .................................... 12

4.4. Obtenção do peso seco das amostras ........................................... 13

4.5. Cálculo dos teores dos pigmentos ................................................ 13

4.6. Índice de Margalef ....................................................................... 14

4.7. Razão clorofila a / feopigmentos ........................................................... 14

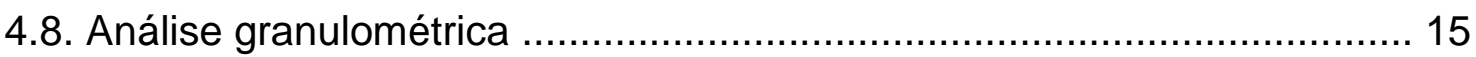

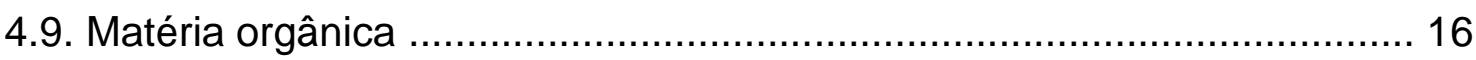

4.10. Teor de carbonato de cálcio........................................................... 16

4.11. Carbono orgânico total .......................................................... 17

4.12. Coeficiente de extinção de luz e irradiância no sedimento ..................... 18

4.13. Tratamento estatístico ..................................................................... 18

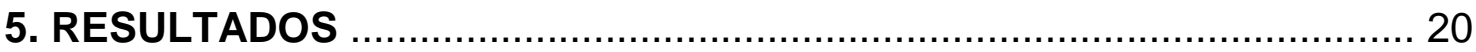

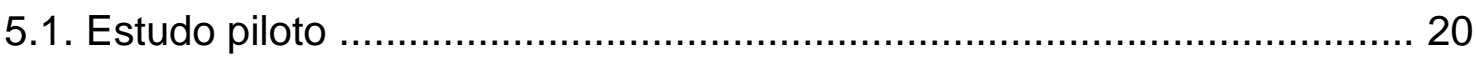

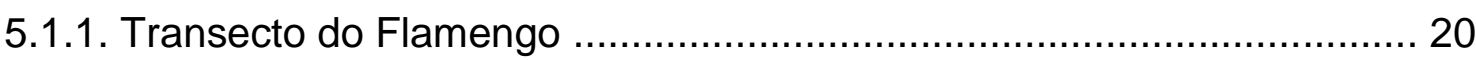

5.1.2. Transecto da Fortaleza ............................................................ 26

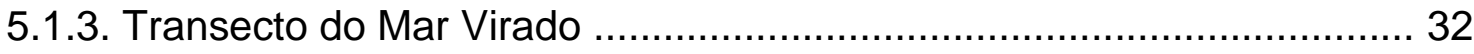




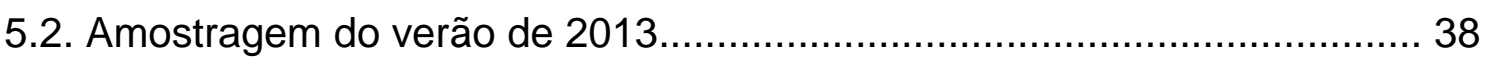

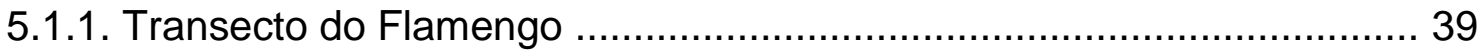

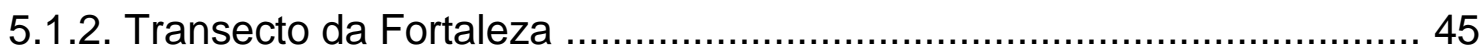

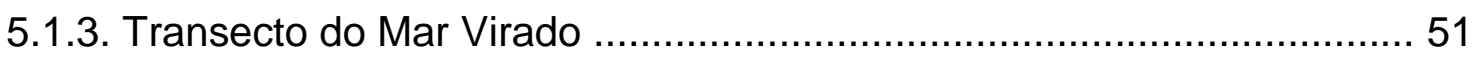

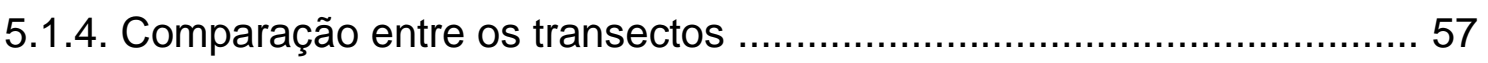

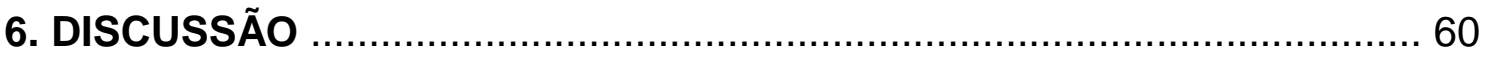

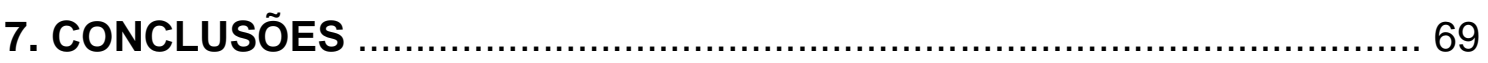

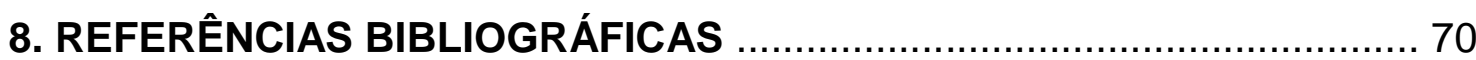




\section{AGRADECIMENTOS}

Primeiramente ao meu Senhor e meu Deus, a quem eu devo tudo!!!

À minha orientadora, a $\operatorname{Prof}^{a}{ }^{a} r^{a}$ Ceci, que me aceitou como estagiário há 5 anos, proporcionando a oportunidade de cursar a pós-graduação que foi o meu objetivo desde o início do estágio. Agradeço por tudo o que aconteceu nestes anos, pela orientação, inclusive pelos puxões de orelha, mas acima de tudo pela amizade e pela companhia.

Aos meus pais, Tarcisio e Nice, que colaboraram e muito antes, durante e após a graduação, permitindo eu ir para o IO fazer estágio voluntário, ao invés de trabalhar com remuneração, pois, isso me rendeu frutos, no qual trabalhos remunerados jamais iriam me proporcionar. Agradeço acima de tudo, pelo amor e carinho que sempre recebi, sem dúvida, eu os amo muito e devo muito a eles por tudo!

Aos colegas do Laboratório de Ecotoxicologia Marinha e Microfitobentos: Luís, Claudinha, Jéssica, Milena, Márcia, Letícia, Renato, Mari, Léo e o Claudio pela ajuda durante as coletas e o trabalho de laboratório.

Ao Prof. Dr. David que esteve presente desde o tempo de graduação (iniciação científica) até a pós-graduação, onde me ajudou durante as coletas e me auxiliou no decorrer do curso. Agradeço também por me apresentar à Profá $\mathrm{Dr}^{\mathrm{a}}$ Ceci, proporcionando assim o estágio e consequentemente a pósgraduação.

Aos técnicos Tomás, André, Luiz, Edilson, Elvis, Giba e Alexandre que me ajudaram participando das coletas ou me auxiliando durante as análises das amostras.

À técnica Drâ. Flávia, que me auxiliou tirando dúvidas conceituais e até mesmo com correções d o trabalho, mas principalmente pela atenção dada. 


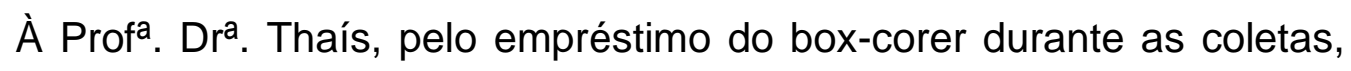
pelo uso do liofilizador.

À Prof ${ }^{a}$. Dra . Bia, pela amizade e simpatia, uma pessoa muito querida.

Ao Prof. Dr. Fred, que tirou algumas dúvidas sobre o meu trabalho, estas foram imprescindíveis para a análise de dados.

Aos colegas Dr. André Rosch e Marcelo Rodrigues por fornecerem a imagem de Ubatuba com os pontos amostrais.

Aos professores Dr. Turra e Drạ. Vanin que fizeram críticas e sugestões positivas no ingresso do mestrado.

À Carol que esteve sempre presente durante a pós-graduação, me incentivando e se preocupando com o andamento do curso.

Ao Instituto Oceanográfico da USP e a todos seus funcionários que de uma ou outra forma me ajudaram: Dona Cida, Cidinha, Letícia, Ana Paula, Silvana, Mirian, Marlene, Airton, Valter, Marta, David, Luciano, Jorge, Daniel, Cida, Vagner, Cido, Marta, Oziel, Daico, Adriano, Manuel entre outros durante esse tempo de IO.

Ao CNPq e a CAPES pelas bolsas concedidas. 


\section{RESUMO}

O microfitobentos é constituído principalmente por diatomáceas, além de fitoflagelados e cianobactérias, distribuindo-se de forma heterogênea no sedimento exposto à luminosidade. O objetivo deste estudo foi avaliar a distribuição espacial da biomassa microfitobentônica no perfil batimétrico da região de Ubatuba, SP. As amostras foram coletadas no verão de 2013, em três transectos (Flamengo, Fortaleza e Mar Virado), com seis pontos cada, coletadas entre as isóbatas de 5 e $30 \mathrm{~m}$. A biomassa foi expressa como clorofila a . Clorofila a e feopigmentos foram extraídos com acetona e medidos em espectrofotômetro. Os valores médios dos pigmentos foram de 18,5 $\pm 11,4$ $\mathrm{mg} \cdot \mathrm{m}^{-2}$ para clorofila a e de $28,4 \pm 16,2 \mathrm{mg} \cdot \mathrm{m}^{-2}$ para feopigmentos no transecto do Flamengo; de 11,9 $\pm 10,2 \mathrm{mg} \cdot \mathrm{m}^{-2}$ para clorofila a e de 18,8 $\pm 15,2 \mathrm{mg} \cdot \mathrm{m}^{-2}$ para feopigmentos no transecto do Mar Virado; e de 11,8 $\pm 11,3 \mathrm{mg} \cdot \mathrm{m}^{-2}$ para clorofila $\underline{a}$ e de $13,7 \pm 13,6 \mathrm{mg} \cdot \mathrm{m}^{-2}$ para feopigmentos no transecto da Fortaleza. Estes valores foram maiores nas regiões mais rasas. A distribuição da biomassa foi associada positivamente com intensidade de luz, silte, argila, matéria orgânica e carbono orgânico total, enquanto foi correlacionada negativamente com profundidade, areia e grânulos.

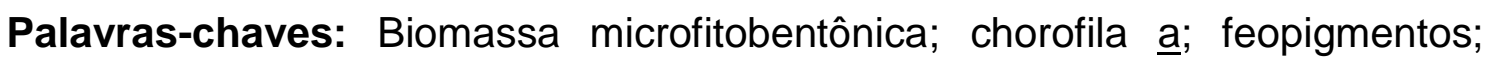
perfil batimétrico; Flamengo; Fortaleza; Mar Virado; Ubatuba. 


\begin{abstract}
Marine microphytobenthos community is composed mainly by diatoms and also phytoflagellates and cyanobacteria, which cover the marine sediments submitted to light. This study aims to survey the spatial distribution of bathymetric profile microphytobenthic biomass in Ubatuba region, SP. The samples were collected in the summer (March, 2013), at three transects: Flamengo, Fortaleza and Mar Virado, with 6 points each, between the isobaths

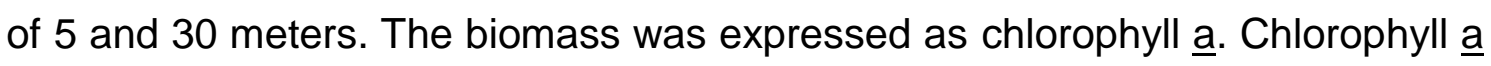
and phaeopigments were extracted with acetone and measured at spectrophotometer. The biomass averages values were: chlorophyll a $18,5 \pm$ $11,4 \mathrm{mg} \cdot \mathrm{m}^{-2}$ and phaeopigments $28,4 \pm 16,2 \mathrm{mg} \cdot \mathrm{m}^{-2}$ for Flamengo transect; chlorophyll a $11,9 \pm 10,2 \mathrm{mg} \cdot \mathrm{m}^{-2}$ and phaeopigments $18,8 \pm 15,2 \mathrm{mg} \cdot \mathrm{m}^{-2}$ for Mar Virado transect; and chlorophyll a 11,8 \pm 11,3 mg.m ${ }^{-2}$ and phaeopigments 13,7 $\pm 13,6 \mathrm{mg} \cdot \mathrm{m}^{-2}$ for Fortaleza transect. Chlorophyll $\underline{\mathrm{a}}$ and phaeopigments averages values were higher in the shallow regions. The biomass distribution was positively associated to light intensity, silt, clay, total organic carbon and organic matter. Negative correlations were found for depth and coarse grains.
\end{abstract}

Key-words: Microphytobenthic biomass; chorophyll a ; phaeopigments; bathymetric profile; Flamengo; Fortaleza; Mar Virado; Ubatuba. 


\section{LISTA DE FIGURAS}

Figura 1: Região de Ubatuba com destaque para as três enseadas e pontos amostrais estudados.

Figura 2: Detalhe da Enseada do Flamengo: Carta Náutica oํ 1635 da DHN (1983) .6

Figura 3: Detalhe da Enseada da Fortaleza: Carta Náutica no 1635 da DHN (1983) .7

Figura 4: Detalhe da Enseada do Mar Virado: Carta Náutica ㄲo 1635 da DHN (1983)

Figura 5: Barco de Pesquisa Véliger // do IO-USP. 10

Figura 6: Coleta do sedimento com box-corer .11

Figura 7: Coleta do centímetro superior $(1 \mathrm{~cm})$ do sedimento com corer e lâmina. 11

Figura 8 a: Distribuição da biomassa média microfitobentônica por amostras no transecto do Flamengo (estudo piloto) 24

Figura 8 b: Distribuição da biomassa média microfitobentônica por pontos amostrais no transecto do Flamengo (estudo piloto) 24

Figura 9 a: Distribuição da biomassa média microfitobentônica por amostras no transecto da Fortaleza (estudo piloto) 30

Figura 9 b: Distribuição da biomassa média microfitobentônica por pontos amostrais no transecto da Fortaleza (estudo piloto) 30 
Figura 10 a: Distribuição da biomassa média microfitobentônica por amostras no transecto do Mar Virado (estudo piloto) 36

Figura 10 b: Distribuição da biomassa média microfitobentônica por pontos amostrais no transecto do Mar Virado (estudo piloto) 36

Figura 11 a: Distribuição da biomassa média microfitobentônica por amostras no transecto do Flamengo (verão de 2013) 42

Figura 11 b: Distribuição da biomassa média microfitobentônica por pontos amostrais no transecto do Flamengo (verão de 2013) 42

Figura 12 a: Distribuição da biomassa média microfitobentônica por amostras no transecto da Fortaleza (verão de 2013) 48

Figura 12 b: Distribuição da biomassa média microfitobentônica por pontos amostrais no transecto da Fortaleza (verão de 2013) 48

Figura 13 a: Distribuição da biomassa média microfitobentônica por amostras no transecto do Mar Virado (verão de 2013) 54

Figura 13 b: Distribuição da biomassa média microfitobentônica por pontos amostrais no transecto do Mar Virado (verão de 2013) 54

Figura 14: Distribuição da biomassa média microfitobentônica por transectos estudados em Ubatuba (verão de 2013) 58 


\section{LISTA DE TABELAS}

Tabela 1: Pontos amostrais estudados 9

Tabela 2: Valores de profundidade (prof.), profundidade de desaparecimento do disco de Secchi (Secchi), temperatura $\left(T^{\circ} \mathrm{O}\right)$, salinidade $(S)$, coeficiente de extinção de luz $(K)$ e irradiância no sedimento $\left(\mathrm{I}_{(z)}\right)$ para o estudo piloto do transecto do Flamengo 21

Tabela 3: Teores de grânulos (Gr.), areia (Ar.), silte (Sil.), argila (Arg.), carbonato de cálcio $\left(\mathrm{CaCO}_{3}\right)$, matéria orgânica (M.O.), carbono orgânico total (C.O.T.), valores de diâmetro médio dos grãos do sedimento $(\Phi)$ e a classificação do sedimento proposta por Folk \& Ward (1957) para o estudo piloto do transecto do Flamengo 21

Tabela 4: Valores das médias e dos desvios padrão amostrais para clorofila a $\left(\mathrm{mg} \cdot \mathrm{m}^{-2}\right)$, feopigmentos $\left(\mathrm{mg} \cdot \mathrm{m}^{-2}\right)$, índice de Margalef e razão $\mathrm{cl} \underline{\text { a } ~ / ~ f e o ~ p a r a ~} 0$ estudo piloto do transecto do Flamengo 23

Tabela 5: Resultados do Teste de Kruskal-Wallis $(\alpha<0,05)$, com a comparação múltipla (do tipo Tukey) de Nemenyi para o estudo piloto do transecto do Flamengo 25

Tabela 6: Correlações $(N=72)$ de Spearman $(r)$, entre as variáveis avaliadas para o estudo piloto do transecto do Flamengo 26

Tabela 7: Valores de profundidade (prof.), profundidade de desaparecimento do disco de Secchi (Secchi), temperatura $\left(T^{\circ} \mathrm{O}\right)$, salinidade $(S)$, coeficiente de extinção de luz $(K)$ e irradiância no sedimento $\left(\mathrm{I}_{(z)}\right)$ para o estudo piloto do transecto da Fortaleza 
Tabela 8: Teores de grânulos (Gr.), areia (Ar.), silte (Sil.), argila (Arg.), carbonato de cálcio $\left(\mathrm{CaCO}_{3}\right)$, matéria orgânica (M.O.), carbono orgânico total (C.O.T.), valores de diâmetro médio dos grãos do sedimento (Ф) e a classificação do sedimento proposta por Folk \& Ward (1957) para o estudo piloto do transecto da Fortaleza

Tabela 9: Valores das médias e dos desvios padrão amostrais para clorofila a (mg. $\mathrm{m}^{-2}$ ), feopigmentos $\left(\mathrm{mg} \cdot \mathrm{m}^{-2}\right)$, índice de Margalef e razão $\mathrm{cl} \underline{\mathrm{a}}$ / feo para o estudo piloto do transecto da Fortaleza 29

Tabela 10: Resultados do Teste de Kruskal-Wallis $(\alpha<0,05)$, com a comparação múltipla (do tipo Tukey) de Nemenyi para o estudo piloto do transecto da Fortaleza 31

Tabela 11: Correlações $(N=72)$ de Spearman $(r)$, entre as variáveis avaliadas para o estudo piloto do transecto da Fortaleza 32

Tabela 12: Valores de profundidade (prof.), profundidade de desaparecimento do disco de Secchi (Secchi), temperatura $\left(\mathrm{T}^{\circ} \mathrm{O}\right)$, salinidade $(\mathrm{S})$, coeficiente de extinção de luz $(\mathrm{K})$ e irradiância no sedimento $\left(\mathrm{I}_{(\mathrm{z})}\right)$ para o estudo piloto do transecto do Mar Virado. 33

Tabela 13: Teores de grânulos (Gr.), areia (Ar.), silte (Sil.), argila (Arg.), carbonato de cálcio $\left(\mathrm{CaCO}_{3}\right)$, matéria orgânica (M.O.), carbono orgânico total (C.O.T.), valores de diâmetro médio dos grãos do sedimento (Ф) e a classificação do sedimento proposta por Folk \& Ward (1957) para o estudo piloto do transecto do Mar Virado 33

Tabela 14: Valores das médias e dos desvios padrão amostrais para clorofila a (mg.m²), feopigmentos $\left(\mathrm{mg} \cdot \mathrm{m}^{-2}\right)$, índice de Margalef e razão $\mathrm{cl} \underline{\mathrm{a}} / \mathrm{feo}$ para $\mathrm{o}$ estudo piloto do transecto do Mar Virado 35 
Tabela 15: Resultados do Teste de Kruskal-Wallis $(\alpha<0,05)$, com a comparação múltipla (do tipo Tukey) de Nemenyi para o estudo piloto do transecto do Mar Virado 37

Tabela 16: Correlações $(N=72)$ de Spearman $(r)$, entre as variáveis avaliadas para o estudo piloto do transecto do Mar Virado 38

Tabela 17: Valores de profundidade (prof.), profundidade de desaparecimento do disco de Secchi (Secchi), temperatura $\left(T^{\circ} \mathrm{O}\right)$, salinidade $(S)$, coeficiente de extinção de luz $(\mathrm{K})$ e irradiância no sedimento $\left(\mathrm{I}_{(z)}\right)$ para a amostragem do verão de 2013 do transecto do Flamengo 39

Tabela 18: Teores de grânulos (Gr.), areia (Ar.), silte (Sil.), argila (Arg.), carbonato de cálcio $\left(\mathrm{CaCO}_{3}\right)$, matéria orgânica (M.O.), carbono orgânico total (C.O.T.), valores de diâmetro médio dos grãos do sedimento $(\Phi)$ e a classificação do sedimento proposta por Folk \& Ward (1957) para a amostragem do verão de 2013 do transecto do Flamengo 40

Tabela 19: Valores das médias e dos desvios padrão amostrais para clorofila $\underline{a}$ (mg.m²), feopigmentos (mg.m²), índice de Margalef e razão $\mathrm{cl}$ a / feo para a amostragem do verão de 2013 do transecto do Flamengo 41

Tabela 20: Resultados do Teste de Kruskal-Wallis $(\alpha<0,05)$, com a comparação múltipla (do tipo Tukey) de Nemenyi para a amostragem do verão de 2013 do transecto do Flamengo 43

Tabela 21: Correlações $(N=72)$ de Spearman $(r)$, entre as variáveis avaliadas para a amostragem do verão de 2013 do transecto do Flamengo 44

Tabela 22: Valores de profundidade (prof.), profundidade de desaparecimento do disco de Secchi (Secchi), temperatura $\left(T^{\circ} \mathrm{O}\right)$, salinidade $(\mathrm{S})$, coeficiente de extinção de luz $(\mathrm{K})$ e irradiância no sedimento $\left(\mathrm{I}_{(z)}\right)$ para a amostragem do verão de 2013 do transecto da Fortaleza 45 
Tabela 23: Teores de grânulos (Gr.), areia (Ar.), silte (Sil.), argila (Arg.), carbonato de cálcio $\left(\mathrm{CaCO}_{3}\right)$, matéria orgânica (M.O.), carbono orgânico total (C.O.T.), valores de diâmetro médio dos grãos do sedimento $(\Phi)$ e a classificação do sedimento proposta por Shepard (1954) e Folk \& Ward (1957) para a amostragem do verão de 2013 do transecto da Fortaleza 46

Tabela 24: Valores das médias e dos desvios padrão amostrais para clorofila a (mg.m²), feopigmentos (mg.m²), índice de Margalef e razão $\mathrm{cl}$ a / feo para a amostragem do verão de 2013 do transecto da Fortaleza 47

Tabela 25: Resultados do Teste de Kruskal-Wallis $(\alpha<0,05)$, com a comparação múltipla (do tipo Tukey) de Nemenyi para a amostragem do verão de 2013 do transecto da Fortaleza 49

Tabela 26: Correlações $(N=72)$ de Spearman $(r)$, entre as variáveis avaliadas para a amostragem do verão de 2013 do transecto da Fortaleza 50

Tabela 27: Valores de profundidade (prof.), profundidade de desaparecimento do disco de Secchi (Secchi), temperatura $\left(T^{\circ} \mathrm{C}\right)$, salinidade $(S)$, coeficiente de extinção de luz $(K)$ e irradiância no sedimento $\left(\mathrm{I}_{(z)}\right)$ para a amostragem do verão de 2013 do transecto do Mar Virado 51

Tabela 28: Teores de grânulos (Gr.), areia (Ar.), silte (Sil.), argila (Arg.), carbonato de cálcio $\left(\mathrm{CaCO}_{3}\right)$, matéria orgânica (M.O.), carbono orgânico total (C.O.T.), valores de diâmetro médio dos grãos do sedimento $(\Phi)$ e a classificação do sedimento proposta por Folk \& Ward (1957) para amostragem do verão de 2013 do transecto do Mar Virado. 52

Tabela 29: Valores das médias e dos desvios padrão amostrais para clorofila a (mg. $\mathrm{m}^{-2}$ ), feopigmentos (mg. $\mathrm{m}^{-2}$ ), índice de Margalef e razão $\mathrm{cl}$ a / feo para a amostragem do verão de 2013 do transecto do Mar Virado 
Tabela 30: Resultados do Teste de Kruskal-Wallis $(\alpha<0,05)$, com a comparação múltipla (do tipo Tukey) de Nemenyi para a amostragem do verão de 2013 do transecto do Mar Virado 55

Tabela 31: Correlações $(N=72)$ de Spearman $(r)$, entre as variáveis avaliadas para a amostragem do verão de 2013 do transecto do Mar Virado 56

Tabela 32: Valores das médias e dos desvios padrão amostrais de clorofila a (mg. $\mathrm{m}^{-2}$ ), feopigmentos (mg. $\mathrm{m}^{-2}$ ), índice de Margalef e razão $\mathrm{cl}$ a / feo para a comparação entre os transectos da amostragem do verão de 2013 57

Tabela 33: Resultados do Teste de Kruskal - Wallis $(\alpha<0,05)$, com a comparação múltipla (do tipo Tukey) de Nemenyi para a amostragem do verão de 2013 dos transectos estudados em Ubatuba 59 


\section{INTRODUÇÃO}

A comunidade microfitobentônica é constituída principalmente por diatomáceas, além de fitoflagelados e cianobactérias, distribuindo-se de forma heterogênea no sedimento (Plante-Cuny, 1978; Odum, 2004; Eichler et al., 2006). As microalgas dessa comunidade são unicelulares, possuindo dimensões entre poucos micrômetros até mais de $500 \mu \mathrm{m}$ e vivem associadas ao sedimento, podendo ser epipsâmicas, quando se fixam aos grãos de areia, ou epipélicas quando se movimentam ativamente nos interstícios do sedimento ou na interface sedimento / água (Plante-Cuny, 1978; Round, 1981; Saburova \& Polikarpov, 2003).

O microfitobentos migra verticalmente no sedimento, em resposta aos estímulos luminosos. Um dos papéis da comunidade consiste na consolidação e manutenção dos sedimentos, recolonização de substratos e auxílio dentro da biogênese de sedimentos e do ciclo biogeoquímico (Palmer \& Round, 1965; Plante-Cuny, 1978; Round, 1981; Guarani et al., 2000; Saburova \& Polikarpov, 2003). Apesar da ocorrência da migração vertical no sedimento, a biomassa fotossinteticamente ativa é concentrada principalmente nos $2 \mathrm{~mm}$ superiores do mesmo (Kelly et al., 2001).

De forma geral, a distribuição do microfitobentos é observada em manchas (Plante-Cuny, 1978; Sousa, 1985; David, 1997). Além disso, a comunidade também é muito bem adaptada ao crescimento em intensidades luminosas entre 1 e $4 \%$ de incidência de luz (Rivkin \& Putt, 1987; Sundbäck \& Granélli, 1988; Sundbäck \& Jönsson, 1988; Cahoon, 1999). Mesmo com adaptação à baixa luminosidade, os fatores mais importantes que influenciam a distribuição são intensidade de luz, profundidade, hidrodinamismo e tamanho dos grãos do sedimento (Plante-Cuny, 1978; Sundbäck \& Jönsson, 1988; Sousa \& David, 1996; Corbisier et al., 1997; Blackford, 2002; Facca \& Sfriso, 2007; Loassachan et al., 2009; Cahoon et al., 2012).

A avaliação da biomassa microfitobentônica é estimada como clorofila a , considerada uma das formas mais eficazes para estudar a comunidade do microfitobentos (Plante-Cuny, 1978; Odum, 2004). Além da clorofila a é medido o teor de feopigmentos, estes são produtos originados através da degradação das moléculas de clorofila de vegetais e de algas autóctones, 
como pelo aporte de vegetais terrestres e / ou pela morte e deposição de microalgas do fitoplâncton no bentos (Plante-Cuny, 1978; Netto et al., 2007).

O microfitobentos é muito diverso, tanto em termos de número de espécies, quanto em formas de vida (Round et al., 1990). Já a produção fitoplanctônica predomina como fonte de matéria orgânica nos oceanos, enquanto que as microalgas bentônicas e as macrófitas podem contribuir significativamente em regiões costeiras e em plataformas continentais (Buscail \& Germain, 1997; Grant et al., 1997; Gillespie et al., 2000; Blackford, 2002; Guarani, et al., 2002). Em águas rasas da região costeira, o microfitobentos é responsável por uma considerável contribuição ao orçamento do carbono. Essa contribuição, em geral, supera a produtividade do fitoplâncton costeiro, com reflexos nos consumidores marinhos (Miller et al., 1996; Cahoon, 1999; Blackford, 2002), alcançando os consumidores terrestres (Day et al., 1989).

Apesar de estudos anteriores terem descrito o sedimento arenoso como pobre e pouco produtivo, diatomáceas bentônicas são abundantes em sedimento de plataforma continental. Quando o habitat bentônico recebe energia luminosa suficiente, a produção primária microfitobentônica pode ser comparável ou até mesmo superior à produção pelágica de uma mesma área, sendo que o ciclo dos elementos biogênicos se concentra no sedimento superficial e na água adjacente. Além disso, existem espécies de diatomáceas bentônicas que são mixotróficas (aptas à heterotrofia na ausência de luz) na zona afótica e em águas mais profundas ou mais escuras (Sundbäck \& Jönsson et al., 1988; Cahoon et al., 1990; De Jonge \& Van Beusekom, 1992; Barranguet, 1997; Tuchman et al., 2006; Cibic et al., 2007 b).

A biomassa microfitobentônica tem uma relação linear com a microbiana, onde as bactérias agem heterotroficamente, utilizando materiral extracelular fornecido pelo microfitobentos, enquanto este utiliza a matéria inorgânica dissolvida mineralizada pelas bactérias. Portanto há uma interação entre os dois grupos (Kunihiro et al., 2012).

O microfitobentos desempenha um importante papel na cadeia trófica, servindo como fonte alimentar para o meiobentos, foraminíferos e algívoros, formando assim uma das bases da teia alimentar, que alcança os níveis mais altos do macro e megabentos, como crustáceos e gastrópodes que pastejam e processam o sedimento epibentônico. Portanto, é necessário o conhecimento 
da distribuição microfitobentônica para entender melhor a distribuição dos taxa algívoros e demais níveis tróficos (Sundbäck \& Person, 1981; Montagna, 1984; Santos et al., 1995; Miller et al., 1996; Macintyre et al., 1996; Gillespie et al., 2000; Pellizzari et al., 2005; Eichler et al., 2006; Yoshino et al., 2006; Netto et al., 2007; Ubertini et al., 2012).

Apesar de sua importância, existem poucos estudos sobre a comunidade microfitobentônica ao longo da costa brasileira, sendo que a maior parte dos trabalhos estão concentrados na zona entremarés. A necessidade do conhecimento da contribuição do microfitobentos para o ambiente costeiro da região de Ubatuba, Litoral Norte do Estado de São Paulo, bem como seu padrão de distribuição no sublitoral formam a base do presente estudo. 


\section{OBJETIVOS}

Estudar a distribuição espacial da biomassa microfitobentônica associada ao perfil batimétrico na região de Ubatuba, com transectos entre os pontos amostrais de 5 (dentro das enseadas do Mar Virado, da Fortaleza e do Flamengo) e $30 \mathrm{~m}$ de profundidade.

Verificar as correlações entre a biomassa e as variáveis ambientais: profundidade, características granulométricas, salinidade, temperatura, matéria orgânica, carbono orgânico total e irradiância no sedimento. 


\section{3. ÁREA DE ESTUDOS}

O município de Ubatuba possui área de $723 \mathrm{~km}^{2}$ com 78.801 habitantes (IBGE, 2014). Este estudo foi realizado com transectos com início dentro das enseadas do Flamengo, da Fortaleza e do Mar Virado e seguindo até a isóbata de 30 metros de profundidade (Fig. 1 e Tab. 1).

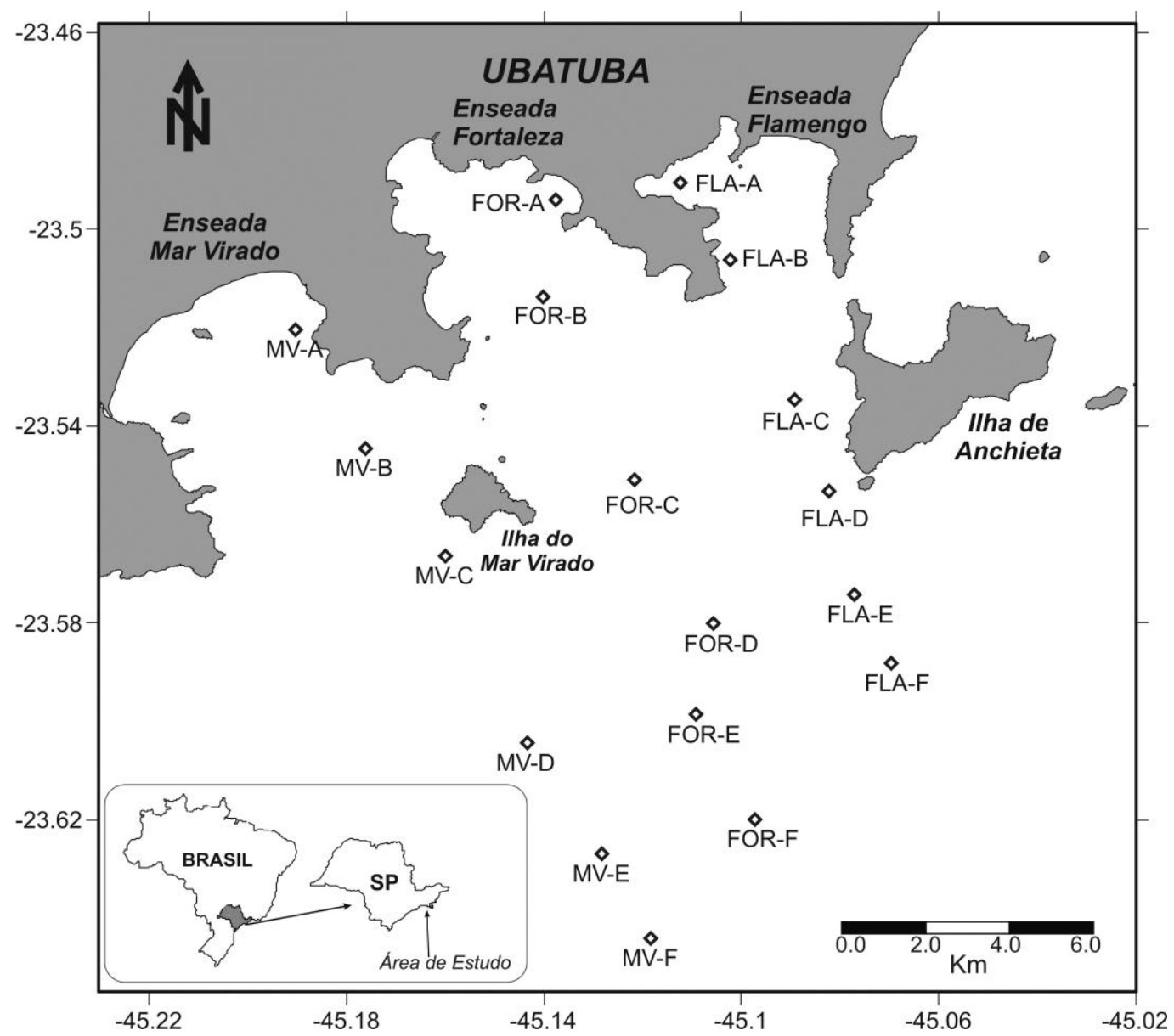

Figura 1: Região de Ubatuba com destaque para as três enseadas e pontos amostrais estudados (De Marcelo Rodrigues, adaptada por André Rosch Rodrigues).

A região é caracterizada pela proximidade da Serra do Mar com a linha de costa, com estreitas faixas de restinga. Na região, a serra apresenta altitudes em torno de $1000 \mathrm{~m}$ alcançando até $1150 \mathrm{~m}$ no Pico do Corcovado. A linha de costa apresenta muitos recortes, formando enseadas, como as estudadas, além de diversos promontórios separando as praias, pequenas ilhas como a de Maranduba e ilhotas próximas às Ilhas do Mar Virado e de Anchieta. Quatro formações de morros individualizam as três enseadas estudadas (DHN, 1983). 


\section{1. Enseada do Flamengo}

A Enseada do Flamengo é delimitada entre o morro da Ponta Grande a oeste e a Ponta da Espia a leste (distância de 2,3 km), que alcança a isóbata de $14 \mathrm{~m}$. Em geral as praias dessa enseada são pequenas (do Flamengo, da Ribeira, do Lamberto, de Perequê Mirim e de Santa Rita), enquanto a Praia da Enseada alcança $1600 \mathrm{~m}$ de extensão. Os morros da Enseada e do Lázaro dominam o fundo da enseada, enquanto o morro do Flamengo domina a oeste e o Morro das Toninhas a leste. Destacam-se os promontórios das pontas do Flamengo, de Santa Rita e da Ribeira, além do Saco da Ribeira a oeste. Após $560 \mathrm{~m}$ da Ponta da Espia inicia-se a llha de Anchieta. Esta enseada é orientada no sentido do sul, $180^{\circ}$, com $3,6 \mathrm{~km}$ de extensão, com declive aproximado de 3,8 $\mathrm{m}$ por $\mathrm{km}$ (DHN, 1983).

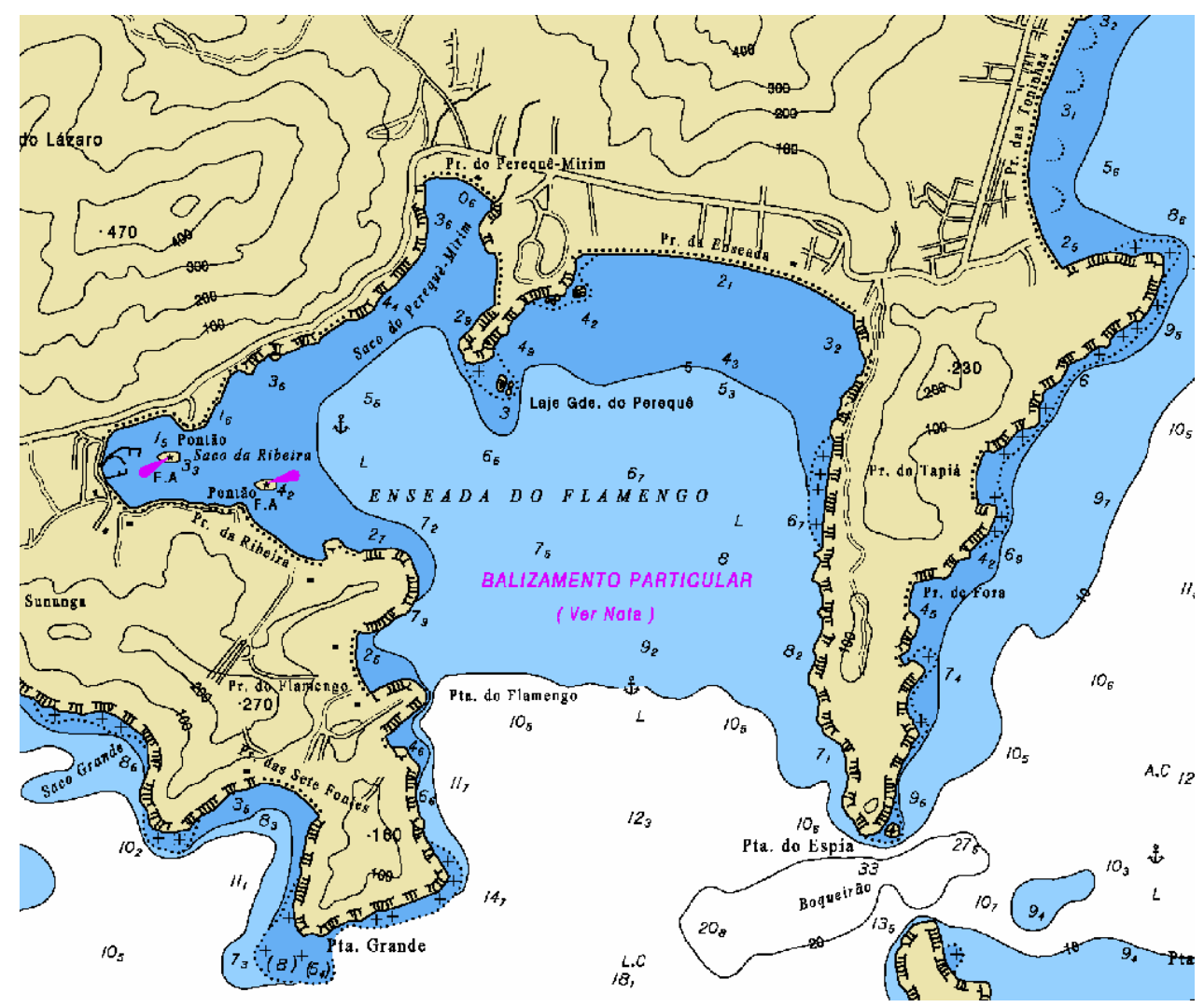

Figura 2: Detalhe da Carta Náutica no 1635 da DHN (1983). 


\section{2. Enseada da Fortaleza}

A Enseada da Fortaleza é delimitada pela Ponta da Fortaleza a oeste e a Ponta Grande a leste (distância de $4,4 \mathrm{~km}$ ), que alcança a isóbata de $10 \mathrm{~m}$. A Praia Dura situa-se ao fundo da enseada, há praias pequenas (Sete Fontes, da Sununga, Domingas Dias, Brava e da Costa), e outras maiores como as praias Dura, do Lázaro e da Fortaleza. Os morros da Lagoinha a oeste e do Flamengo a leste dominam a enseada, com destaque para os promontórios das pontas da Fortaleza e da Sununga. A enseada é orientada no sentido sudeste, $160^{\circ}$, com $5,2 \mathrm{~km}$ de extensão, com declive aproximado de $2 \mathrm{~m}$ por km (DHN, 1983).

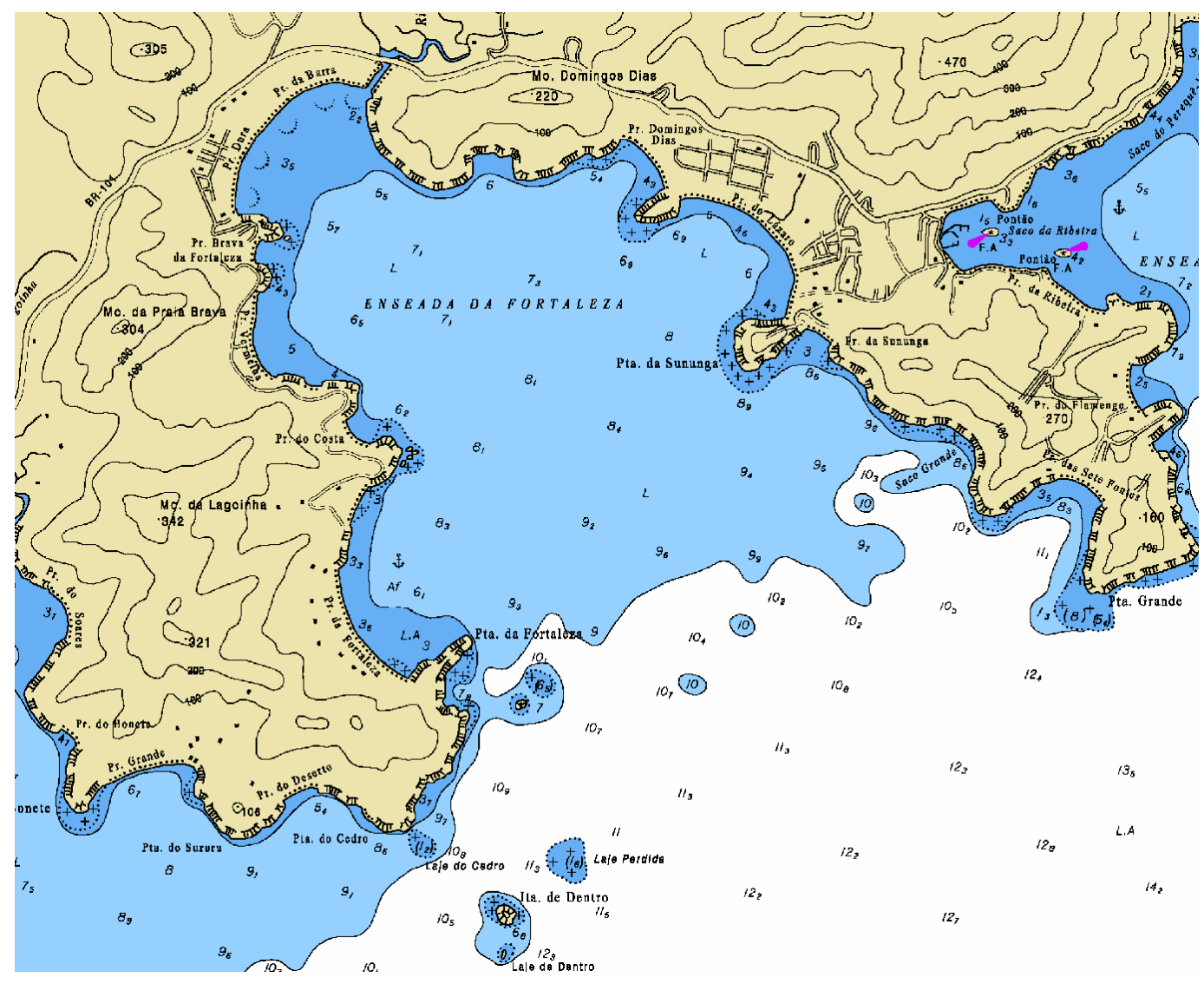

Figura 3: Detalhe da Carta Náutica oㅜ 1635 da DHN (1983). 


\subsection{Enseada do Mar Virado}

A Enseada do Mar Virado está delimitada entre a Ponta Lisa a oeste e a Ponta Grossa a leste (distância de $6 \mathrm{~km}$ ), e neste alinhamento alcança a isóbata de $10 \mathrm{~m}$. O morro do Sapé domina o fundo da enseada enquanto a oeste domina a Serra da Cassandoca com as praias do Pulso, Cassandoca e costões rochosos que margeiam o litoral. A leste, o Morro da Lagoinha é margeado pelas praias do Soares, do Bonete e do Cedro, além de costões rochosos. Destacam-se ainda as ilhas menores, de Maranduba e da Ponta, próximas à Praia de Maranduba; e a llha do Mar Virado na entrada, a sudeste da enseada. Esta enseada é orientada no sentido do sudeste, $150^{\circ}$, com aproximadamente $5 \mathrm{~km}$ de extensão, com um declive aproximado de $2 \mathrm{~m}$ por km (DHN, 1983).

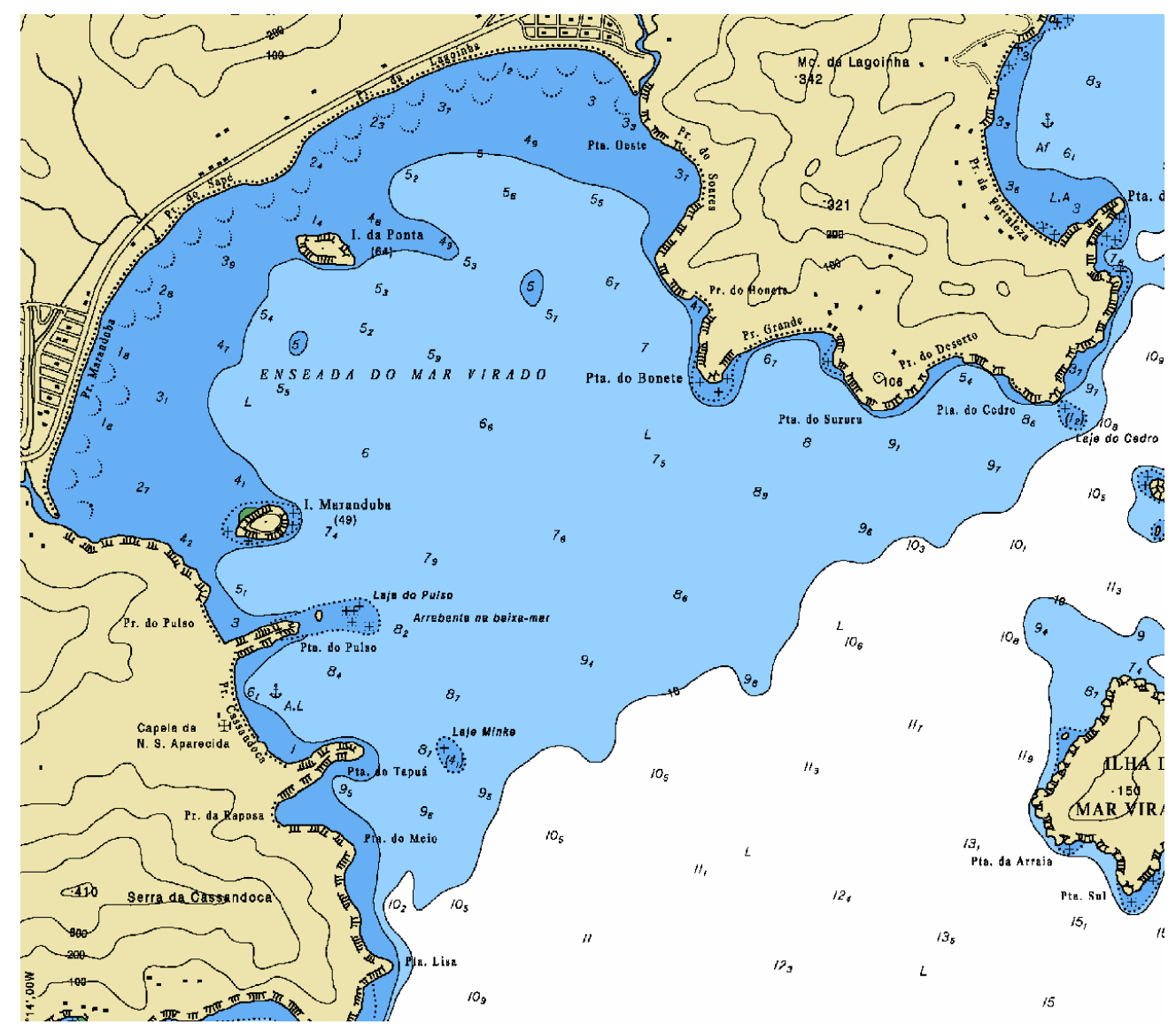

Figura 4: Detalhe da Carta Náutica oํ 1635 da DHN (1983). 


\section{MATERIAIS E MÉTODOS}

\section{1. Procedimentos de amostragem do microfitobentos}

As amostras do microfitobentos foram coletadas do sedimento no perfil batimétrico em três transectos transversais à linha de costa. $O$ primeiro iniciando dentro da Enseada do Flamengo (FLA), o segundo iniciando dentro da Enseada da Fortaleza (FOR) e o terceiro iniciando dentro da Enseada do Mar Virado (MV), com seis pontos amostrais cada (A, B, C, D, E e F), nas profundidades de 5, 10, 15, 20, 25 e 30 m respectivamente (Fig. 1 e Tab. 1). Em cada ponto amostral foram coletadas 3 amostras com 4 réplicas cada amostra. Para as coletas, obteve-se o apoio da Base Clarimundo de Jesus do Instituto Oceanográfico da Universidade de São Paulo (IO-USP).

Tabela 1: Pontos amostrais estudados.

\begin{tabular}{c|c|c|c}
\hline Pontos amostrais & Latidude & Longitude & Profundidade (m) \\
\hline FLA A & $23^{\circ} 30,085^{\prime} \mathrm{S}$ & $45^{\circ} 06,643^{\prime} \mathrm{W}$ & 5 \\
\hline FLA B & $23^{\circ} 30,950^{\prime} \mathrm{S}$ & $45^{\circ} 06,149^{\prime} \mathrm{W}$ & 10 \\
\hline FLA C & $23^{\circ} 32,672^{\prime} \mathrm{S}$ & $45^{\circ} 05,386^{\prime} \mathrm{W}$ & 15 \\
\hline FLA D & $23^{\circ} 33,704^{\prime} \mathrm{S}$ & $45^{\circ} 04,966^{\prime} \mathrm{W}$ & 20 \\
\hline FLA E & $23^{\circ} 34,465^{\prime} \mathrm{S}$ & $45^{\circ} 04,630^{\prime} \mathrm{W}$ & 25 \\
\hline FLA F & $23^{\circ} 35,288^{\prime} \mathrm{S}$ & $45^{\circ} 04,176^{\prime} \mathrm{W}$ & 30 \\
\hline FOR A & $23^{\circ} 30,276^{\prime} \mathrm{S}$ & $45^{\circ} 08,275^{\prime} \mathrm{W}$ & 5 \\
\hline FOR B & $23^{\circ} 31,746^{\prime} \mathrm{S}$ & $45^{\circ} 08,351^{\prime} \mathrm{W}$ & 10 \\
\hline FOR C & $23^{\circ} 33,755^{\prime} \mathrm{S}$ & $45^{\circ} 07,103^{\prime} \mathrm{W}$ & 15 \\
\hline FOR D & $23^{\circ} 34,808^{\prime} \mathrm{S}$ & $45^{\circ} 06,344^{\prime} \mathrm{W}$ & 20 \\
\hline FOR E & $23^{\circ} 35,917^{\prime} \mathrm{S}$ & $45^{\circ} 06,549^{\prime} \mathrm{W}$ & 25 \\
\hline FOR F & $23^{\circ} 37,197^{\prime} \mathrm{S}$ & $45^{\circ} 05,835^{\prime} \mathrm{W}$ & 30 \\
\hline MV A & $23^{\circ} 31,966^{\prime} \mathrm{S}$ & $45^{\circ} 11,502^{\prime} \mathrm{W}$ & 5 \\
\hline MV B & $23^{\circ} 33,423^{\prime} \mathrm{S}$ & $45^{\circ} 10,651^{\prime} \mathrm{W}$ & 10 \\
\hline MV C & $23^{\circ} 34,738^{\prime} \mathrm{S}$ & $45^{\circ} 09,680^{\prime} \mathrm{W}$ & 15 \\
\hline MV D & $23^{\circ} 36,260^{\prime} \mathrm{S}$ & $45^{\circ} 08,606^{\prime} \mathrm{W}$ & 20 \\
\hline MV E & $23^{\circ} 37,614^{\prime} \mathrm{S}$ & $45^{\circ} 07,690^{\prime} \mathrm{W}$ & 25 \\
\hline MV F & $23^{\circ} 38,643^{\prime} \mathrm{S}$ & $45^{\circ} 07,099^{\prime} \mathrm{W}$ & 30 \\
\hline & & & \\
\hline
\end{tabular}


Os transectos foram realizados com pontos amostrais entre as isóbatas de 5 (ponto amostral A) e $30 \mathrm{~m}$ (ponto amostral F).

Foi realizado um estudo piloto em 24 e 25 de fevereiro de 2012 e a amostragem de verão nos dias 09 e 10 de março de 2013. Para coletar o sedimento, foi utilizado o box-corer de 20 × $20 \mathrm{~cm}$ (Fig. 6) a bordo do Barco de Pesquisa Véliger II do IO-USP (Fig. 5) Para cada ponto amostral, o box-corer foi lançado três vezes.

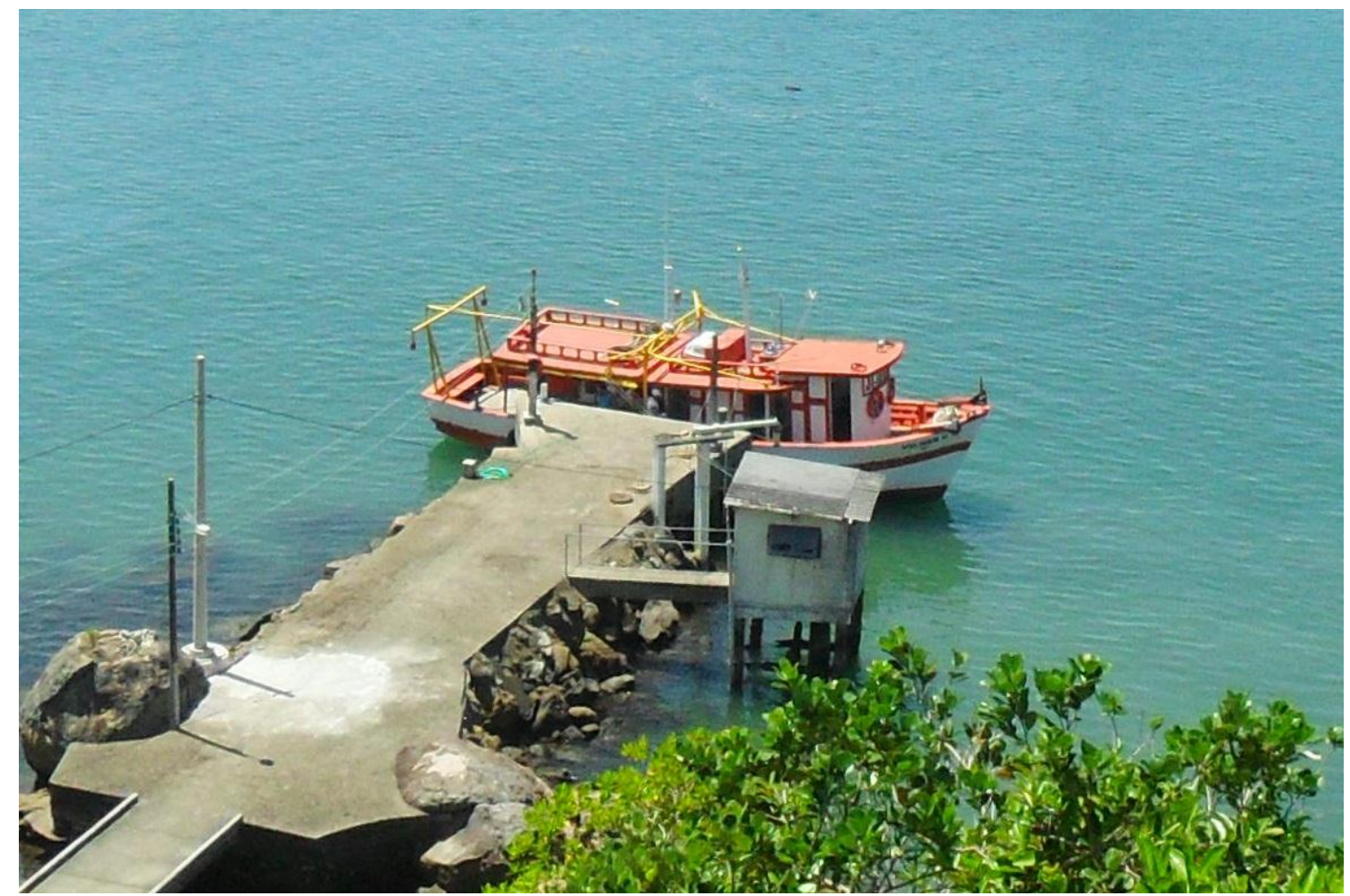

Figura 5: Barco de Pesquisa Véliger I/ do IO-USP (De Cristiano de Salles Almeida). 


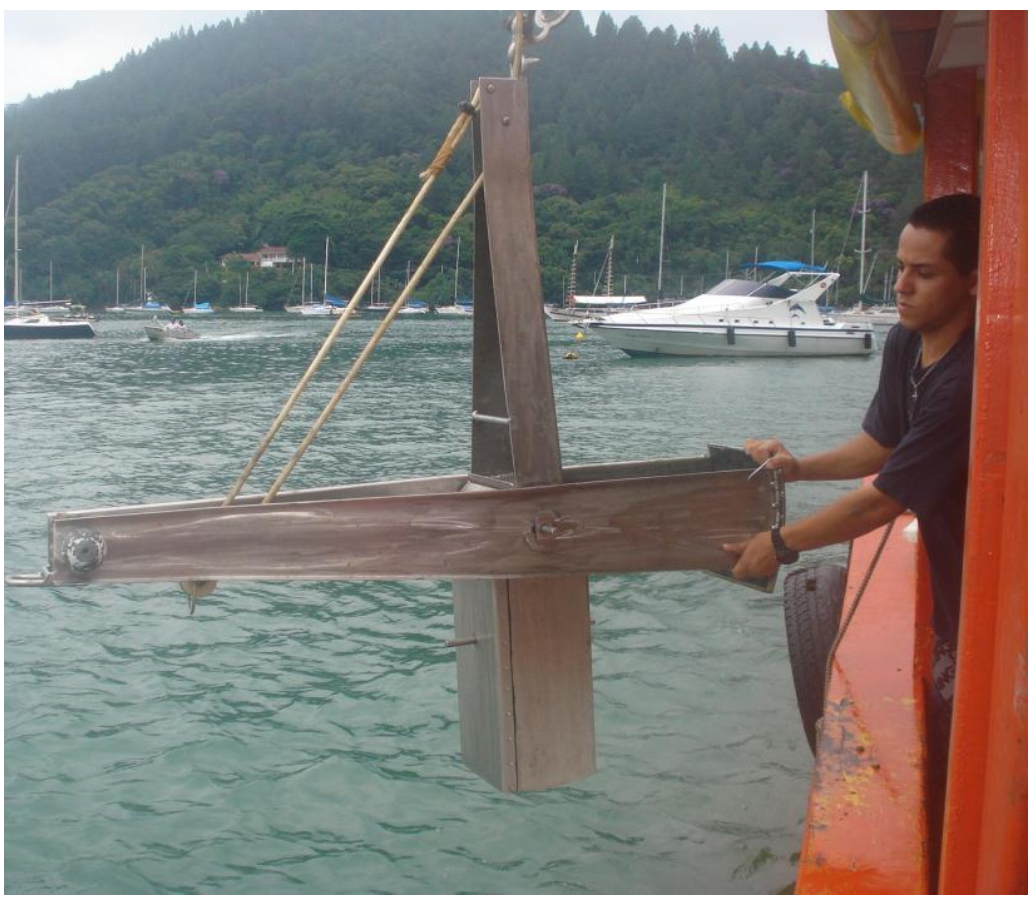

Figura 6: Coleta (piloto) do sedimento com box-corer (De Carlos João David).

Após a coleta do sedimento, a água sobrenadante foi retirada do boxcorer com auxílio de uma mangueira (sifão). Em seguida foi retirado o centímetro superior $(1 \mathrm{~cm})$ do sedimento com um corer de $2 \mathrm{~cm}$ de diâmetro interno conforme a figura 7 (Plante-Cuny, 1978, David et al., 2003, Almeida et al., 2009 e David et al., 2010).

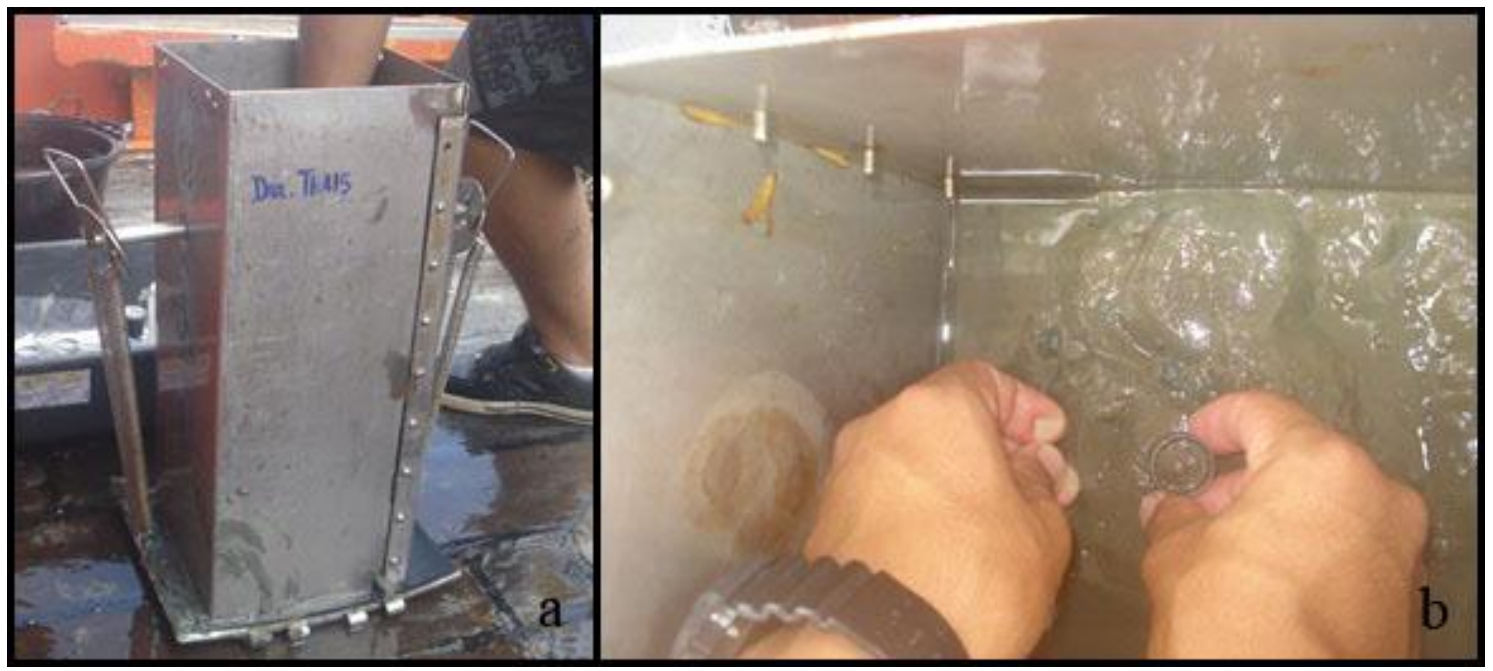

Figura 7: Coleta (piloto) do centímetro superior $(1 \mathrm{~cm})$ do sedimento com corer e lâmina (De Carlos João David). 
Após a coleta das amostras, estas foram armazenadas em frascos escuros e mantidas em recipiente isotérmico com gelo, transportadas para 0 laboratório e mantidas congeladas até a ocasião do processamento segundo a metodologia de Plante-Cuny (1978). As amostras foram processadas no Laboratório de Ecotoxicologia Marinha e Microfitobentos do IO-USP.

\section{2. Extração dos pigmentos}

A biomassa foi estimada pela avaliação dos pigmentos fotossintetizantes, a clorofila a e os feopigmentos de acordo com o método descrito por Plante-Cuny (1978), com adaptações feitas por David (1997) descritas a seguir:

As amostras úmidas foram pesadas. Após a pesagem foi adicionado $0,07 \mathrm{~g}$ de $\mathrm{MgCO}_{3}$ e $10 \mathrm{ml}$ de acetona P. A. a $100 \%$ em cada amostra. A extração dos pigmentos foi processada em refrigerador por um período entre 20 e 24 horas.

\section{3. Avaliação espectrofotométrica dos pigmentos}

Após a extração, as amostras foram colocadas em um tubo de ensaio e centrifugadas a 2500 r. p. m. (rotações por minuto) por um período de 10 minutos.

Em seguida foi feita a retirada do sobrenadante de cada amostra para realização das leituras das absorbâncias em espectrofotômetro nos comprimentos de ondas de 430, 665, e 750 ๆm para a avaliação da clorofila a Após a leitura da clorofila $\underline{\text { a }}$, as amostras foram acidificadas com 2 gotas de $\mathrm{HCl}(1 \mathrm{~N})$, e em seguida refeitas as leituras nos mesmos comprimentos de ondas para a obtenção dos teores de feopigmentos.

Todos os procedimentos, da extração à leitura em espectrofotômetro foram realizados evitando-se ao máximo a exposição das amostras à luz e calor a fim de evitar a foto e termo-degradação dos pigmentos. 


\section{4. Obtenção do peso seco das amostras}

Após a retirada do sobrenadante para a quantificação dos pigmentos, as amostras foram secas em estufa a $60{ }^{\circ} \mathrm{C}$ por 48 horas para obtenção do peso seco.

\section{5. Cálculo dos teores dos pigmentos}

Os cálculos para se obter os teores de clorofila a e feopigmentos foram realizados utilizando as seguintes equações de Plante-Cuny (1978):

$\mathrm{Cl} \underline{\mathrm{a}}\left(\mu \mathrm{g} \cdot \mathrm{g}^{-1}\right)=\frac{26,7(\mathrm{DO6650}-\mathrm{DO} 7500)-(\mathrm{DO665a}-\mathrm{DO} 750 \mathrm{a}) \cdot \text { vol. água da amostra }\left(\mathrm{cm}^{3}\right)+\text { vol. acetona }\left(\mathrm{cm}^{3}\right)}{\mathrm{-ano} \text { da amostra seca }(\mathrm{g}) \text {. trajeto óptico da cubeta }(\mathrm{cm})}$ Feo $\left(\mu \mathrm{g} . \mathrm{g}^{-1}\right)=\frac{26,7\{[1,7 .(\mathrm{DO} 65 \mathrm{a}-\mathrm{DO} 750 \mathrm{a})]-(\mathrm{DO} 650 \mathrm{o}-\mathrm{DO} 550 \mathrm{o})\} \text {. vol. água da amostra }\left(\mathrm{cm}^{3}\right)+\text { vol. acetona }\left(\mathrm{cm}^{3}\right)}{\text { peso da amostra seca }(\mathrm{g}) \text {. trajeto óptico da cubeta }(\mathrm{cm})}$

Entretanto, os resultados, em geral, são expressos em termos de área nos estudos ecológicos e de caracterização de ambientes. Portanto, os dados em micrograma de biomassa por grama de sedimento foram convertidos em miligrama de biomassa para uma superfície (metro quadrado), apresentadas a seguir, conforme Plante-Cuny (1978):

$\mathrm{Cl} \underline{\mathrm{a}}\left(\mathrm{mg} \cdot \mathrm{m}^{-2}\right)=\left(\underline{\mathrm{a}}\left(\mu \mathrm{g} \cdot \mathrm{g}^{-1}\right) \cdot\right.$ peso seco da amostra $(\mathrm{g}) \cdot \mathrm{MV} .10 \cdot$ trajeto óptico da cubeta $(\mathrm{cm})$
Feo $\left(\mathrm{mg} \cdot \mathrm{m}^{-2}\right)=-$ Feo da amostra úmida $(\mathrm{g})$
peso da amostra úmida $(\mathrm{g})$

Onde:

26,7 = taxa de absorção da clorofila a

1,7 = taxa de C665 / F665;

$\mathrm{MV}=$ massa volumétrica do sedimento úmido (peso da amostra úmida / $\left.\pi \cdot r^{2} \cdot h\right)$; 
10 = Fator de conversão (faz corresponder $\mu \mathrm{g} \cdot \mathrm{cm}^{-2}$ a mg.m ${ }^{-2}$ );

DO 6650 = leitura da densidade óptica em $665 \mathrm{\eta m}$ antes da acidificação;

DO 665a = leitura da densidade óptica em 665 ๆm após a acidificação;

DO 7500 = leitura da densidade óptica em $750 \eta \mathrm{m}$ antes da acidificação;

DO 750a = leitura da densidade óptica em 750 ๆm após a acidificação.

\section{6. Índice de Margalef}

O índice pigmentar de Margalef (Margalef, 1974) que indica comunidades jovens ou senescentes, foi calculado pela relação entre as densidades ópticas DO 430o / DO 665o:

Indíce de Margalef $=\frac{\text { DO 430o }}{\text { DO 6650 }}$

Onde:

DO 4300 = Leitura da densidade óptica em $430 \eta \mathrm{m}$ antes da acidificação;

DO 6650 = Leitura da densidade óptica em $665 \eta \mathrm{m}$ antes da acidificação.

\section{7. Razão clorofila a / feopigmentos}

A razão clorofila a (cl $\underline{\mathrm{a}}$ ) / feopigmentos (feo) foi calculada pela relação:

$$
\text { Razão }=\frac{\mathrm{Cl} \underline{\mathrm{a}}}{-\mathrm{Feo}}
$$




\section{8. Análise granulométrica}

Para a análise granulométrica, foram utilizadas amostras de sedimento coletadas do box-corer de onde foram retiradas as amostras para 0 microfitobentos. As amostras foram armazenadas em sacos plásticos, congeladas e antes da análise foi feita a liofilização, processo pelo qual a água contida na amostra é retirada por sublimação, ou seja, sem passagem pela fase líquida. Estas amostras foram analisadas através do método de peneiramento e pipetagem de Suguio (1973), adaptado por Mahiques (1987). Também foi avaliada a distribuição do sedimento utilizando os parâmetros e a classificação granulométrica de Folk \& Ward (1957).

De acordo com o método de Suguio (1973), adaptado por Mahiques (1987), alíquotas de $25 \mathrm{~g}$ de sedimento foram pesadas e foi eliminada a matéria orgânica contida nas amostras através de tratamento com peróxido de hidrogênio $\left(\mathrm{H}_{2} \mathrm{O}_{2}\right)$ diluído a $10 \%$ para não interferir no processo de pipetagem. Após a eliminação da matéria orgânica, o material foi seco em estufa a $45^{\circ} \mathrm{C}$, por um período de $48 \mathrm{~h}$ e depois pesado em balança analítica, e em seguida foram realizados os procedimentos de peneiramento e pipetagem.

Após a secagem do sedimento livre de matéria orgânica, foi adicionado cerca de $20 \mathrm{~mL}$ de água destilada na amostra. Posteriormente foi realizado o peneiramento úmido das frações mais finas do sedimento utilizando a peneira de malha $0,062 \mathrm{~mm}$. O material retido na peneira foi seco em estufa e depois peneirado, constituindo-se a fração mais grossa. Este sedimento foi separado, utilizando-se um jogo de peneiras da marca Granutest, com malhas de 2,0 mm a $0,062 \mathrm{~mm}$ e com intervalos de $0,5 \mathrm{~mm}$ em um agitador RO-TAP por um período de 15 minutos. O sedimento retido em cada peneira foi pesado e anotado.

A fração fina $(<0,062 \mathrm{~mm})$ foi colocada em suspensão em água destilada, em proveta graduada de $1000 \mathrm{~mL}$. Para evitar a floculação, foi adicionado $1 \mathrm{~g}$ de pirofosfato de sódio $\left(\mathrm{Na}_{4} \mathrm{P}_{2} \mathrm{O}_{7}\right)$, seguindo-se então a pipetagem do material. Após a pipetagem, as alíquotas coletadas foram secas em estufa e depois pesadas. Este método de pipetagem baseia-se na Lei de Stokes, que tem como princípio básico a velocidade de decantação das partículas. 
A distribuição dos tamanhos de grãos em cada ponto amostral foi analisada estatisticamente através das equações propostas por Folk \& Ward (1957), com a utilização do software Labse.

\section{9. Matéria orgânica}

Conforme o método de Suguio (1973), o teor de matéria orgânica no sedimento foi obtido utilizando o tratamento com peróxido de hidrogênio $\left(\mathrm{H}_{2} \mathrm{O}_{2}\right)$ diluído a $10 \%$. As amostras foram pesadas $(25 \mathrm{~g})$ em béqueres, e em seguida foi adicionado $\mathrm{H}_{2} \mathrm{O}_{2}$ para eliminação da matéria orgânica. Após a eliminação completa da matéria orgânica, as amostras foram lavadas com água destilada para eliminação do $\mathrm{H}_{2} \mathrm{O}_{2}$ e posteriormente secas em estufa a $45^{\circ} \mathrm{C}$.

A concentração de matéria orgânica foi determinada através da diferença de massa antes e após o tratamento com $\mathrm{H}_{2} \mathrm{O}_{2}$. Após a secagem, foi feita uma nova pesagem, e os pesos finais e iniciais foram comparados para obter o teor de matéria orgânica em porcentagem conforme a fórmula abaixo:

Teor de matéria orgânica $=\left(\mathrm{P}_{\text {final }} / \mathrm{P}_{\text {inicial }}\right) * 100$

Onde:

$P_{\text {inicial }}=$ peso inicial da amostra;

$P_{\text {final }}=$ peso final da amostra.

\section{10. Teor de carbonato de cálcio}

Conforme o método de Suguio (1973), o teor de carbonato de cálcio $\left(\mathrm{CaCO}_{3}\right)$ no sedimento foi obtido utilizando o processo da dissolução do carbonato em ácido clorídrico $(\mathrm{HCl})$ a $10 \%$. Para cada amostra, foram pesados $10 \mathrm{~g}$ de sedimento em béqueres, e em seguida acidificados para eliminação do $\mathrm{CaCO}_{3}$. Após a eliminação completa do $\mathrm{CaCO}_{3}$, as amostras foram lavadas com água destilada para eliminação do ácido e posteriormente secas em estufa a $45^{\circ} \mathrm{C}$.

A concentração de $\mathrm{CaCO}_{3}$ foi determinada através da diferença de massa antes e após o tratamento com $\mathrm{HCl}$. Após a secagem, foi feita uma nova 
pesagem, e os pesos finais e iniciais foram comparados para obter o teor de $\mathrm{CaCO}_{3}$ em porcentagem conforme a fórmula abaixo:

Teor de $\mathrm{CaCO}_{3}=\left(\mathrm{P}_{\text {final }} / \mathrm{P}_{\text {inicial }}\right) * 100$

Onde:

$P_{\text {inicial }}=$ peso inicial da amostra;

$P_{\text {final }}=$ peso final da amostra.

\section{11. Carbono orgânico total}

O carbono orgânico total no sedimento foi obtido utilizando-se o método de Gaudete et al. (1974). Na análise, 0,3 g de sedimento liofilizado e pulverizado foi pesado e transferido para um erlenmeyer, onde $10 \mathrm{~mL}$ de dicromato de potássio $\left(\mathrm{K}_{2} \mathrm{Cr}_{2} \mathrm{O}_{7}\right)$ e $20 \mathrm{~mL}$ de ácido sulfúrico $\left(\mathrm{H}_{2} \mathrm{SO}_{4}\right)$ concentrado foram adicionados lentamente e de forma contínua, girando o erlenmeyer para homogeneizar a reação, com o cuidado de não espalhar 0 sedimento nas paredes da vidraria. A solução resultante permaneceu em repouso por 30 minutos.

Após o período de repouso, as soluções foram diluídas para $200 \mathrm{~mL}$ com água destilada. Em seguida foram adicionados $10 \mathrm{~mL}$ de ácido fosfórico $\left(\mathrm{H}_{3} \mathrm{PO}_{4}\right)$ a $85 \%$, 0,2 $\mathrm{g}$ de fluoreto de sódio $(\mathrm{NaF})$ e 7 gotas de indicador difenilamina. A solução resultante foi então titulada com sulfato ferroso amoniacal $0,50 \mathrm{~N}$. Na medida em que a coloração se aproximou da coloração cinza azulada, a titulação passou a ser feita gota a gota até a mudança da cor azul para verde brilhante, que indica o ponto de viragem, final do procedimento.

Os valores de carbono orgânico total foram calculados utilizando a seguinte equação:

$$
[\% \mathrm{C} \text { org }]=\mathrm{V}^{*}(1-\mathrm{T} / \mathrm{TBr})^{\star} 0,003^{*} \mathrm{~N}^{*}(100 / \mathrm{m})
$$


Onde:

$\mathrm{V}=$ volume de dicromato de potássio utilizado $(\mathrm{mL})$;

$\mathrm{N}=$ normalidade do dicromato de potássio;

$T=$ volume de sulfato ferroso amoniacal gasto na amostra $(\mathrm{mL})$;

$\mathrm{TBr}=$ volume de sulfato ferroso amoniacal gasto no branco $(\mathrm{mL})$;

$\mathrm{m}=$ peso da amostra de sedimento $(\mathrm{g})$;

$0,003=12 / 400=$ mili equivalente em peso de carbono.

\section{12. Coeficiente de extinção de luz e irradiância no sedimento}

O coeficiente de extinção de luz foi obtido através do lançamento do disco de Secchi e calculado pela equação proposta por Poole \& Atikins (1929):

$$
K=\frac{1,7}{D}
$$

Onde $\mathrm{D}$ é a profundidade de desaparecimento do disco de Secchi.

A partir do k obtido de cada lançamento do disco de Secchi, seguindo a Lei de Lambert-Bouguer para a atenuação da luz, foi possível calcular o percentual de irradiância no sedimento $\left(\mathrm{I}_{(\mathrm{z})}\right)$ em cada um dos pontos amostrados, através da equação:

$I_{(z)}=I_{(0)} x e^{(-k x z)}$

Onde $z$ é a profundidade em metros;

$\mathrm{I}_{(\mathrm{z})}=$ irradiância na profundidade $\mathrm{z}$;

$\mathrm{I}_{(0)}=$ irradiância na superfície $=100(\%)$;

e (número neperiano) $=2,718$.

\section{12. Tratamento estatístico}

Primeiramente foi aplicado o teste de normalidade de Kolmogorov Smirnov para verificar se as amostras do microfitobentos tinham homocedasticidade. Após verificar que não houve homocedasticidade, foi 
aplicado o teste estatístico não paramétrico Kruskal - Wallis (análise de variância) para verificar as diferenças significativas $(\alpha<0,05)$ entre os pontos médios amostrais. Devido não ter ocorrido diferença significativa entre as amostras dos 3 boxes-corer (4 réplicas por box-corer) de cada ponto amostral (na maioria dos pontos amostrais), a análise de variância foi aplicada aos pontos médios amostrais (12 réplicas), com a comparação múltipla (do tipo Tukey) de Nemenyi. Para finalizar foi aplicada a correlação de Spearman entre a biomassa e as variáveis ambientais como profundidade, salinidade (medida com refratômetro), temperatura (medida com termômetro acoplado à garrafa de Nansen), coeficiente de extinção de luz e irradiância no sedimento, características granulométricas, matéria orgânica, carbono orgânico total, carbonato de cálcio e os índices de Margalef e clorofila a / feopigmentos. Foram consideradas as correlações entre 0 e 1 e entre 0 e - 1 (Zar, 2010), onde adotou-se a classificação "correlação forte" para as correlações iguais ou superiores a 0,8 . 


\section{RESULTADOS}

Primeiramente serão apresentados os resultados do estudo piloto, comparando as amostras dos pontos de cada transecto, conforme os itens "5.1.1.", "5.1.2." e "5.1.3.", com o intuito de verificar se houve diferença entre os pontos amostrais nas diferentes profundidades.

Posteriormente serão apresentados os resultados da amostragem do verão de 2013, comparando as amostras dos pontos de cada transecto, conforme os itens 5.2.1., 5.2.2. e 5.2.3., com o intuito de verificar se houve diferença entre os pontos amostrais nas diferentes profundidades.

Por último, serão apresentados os resultados médios dos transectos, comparando-os entre si, sem analisar as diferentes profundidades, mas apenas com o intuito de verificar se houve diferença entre os transectos, conforme o item 5.2.4.

\section{1. Estudo piloto}

Nos itens "5.1.1.", "5.1.2." e "5.1.3." serão apresentados os resultados do estudo piloto para os transectos do Flamengo, da Fortaleza e do Mar Virado respectivamente.

\section{1. 1. Transecto do Flamengo}

A tabela 2 apresenta os resultados ambientais, tais como profundidade dos pontos de coleta, profundidade de desaparecimento do disco de Secchi, temperatura, salinidade, coeficiente de luz e irradiância no sedimento. 
Tabela 2: Valores de profundidade (prof.), profundidade de desaparecimento do disco de Secchi (Secchi), temperatura $\left(\mathrm{T}^{\circ} \mathrm{O} \mathrm{C}\right)$, salinidade (S), coeficiente de extinção de luz $(\mathrm{K})$ e irradiância no sedimento $\left(\mathrm{I}_{(\mathrm{z})}\right)$ para o estudo piloto do transecto do Flamengo.

\begin{tabular}{c|c|c|c|c|c|c}
\hline $\begin{array}{c}\text { Pontos } \\
\text { amostrais }\end{array}$ & Prof. & Secchi & $\mathrm{T} \stackrel{\circ}{\circ}$ & $\mathrm{S}$ & $\mathrm{K}$ & $\mathrm{I}_{(\mathrm{z})}(\%)$ \\
\hline A & 5 & 3,5 & 24,40 & 36 & 0,486 & 8,818 \\
\hline B & 10 & 4,5 & 27,85 & 37 & 0,378 & 2,288 \\
\hline C & 15 & 6,0 & 25,70 & 37 & 0,283 & 1,427 \\
\hline D & 20 & 6,0 & 26,35 & 37 & 0,283 & 0,346 \\
\hline E & 25 & 7,0 & 24,00 & 37 & 0,243 & 0,231 \\
\hline F & 30 & 8,5 & 26,00 & 37 & 0,200 & 0,248 \\
\hline
\end{tabular}

A profundidade de desaparecimento do disco de Secchi variou entre 3,5 e 8,5 metros, a temperatura variou entre 24,00 e $27,85^{\circ} \mathrm{C}$, a salinidade variou entre 36 e 37, o coeficiente de extinção de luz variou entre 0,200 e 0,486 e a irradiância no sedimento variou entre 0,231 e 8,818\% (Tab. 2).

A tabela 3 apresenta os teores granulométricos, teores de carbonato de cálcio, de matéria orgânica e de carbono orgânico total, valores de diâmetro médio dos grãos do sedimento e a classificação do sedimento.

Tabela 3: Teores de grânulos (Gr.), areia (Ar.), silte (Sil.), argila (Arg.), carbonato de cálcio $\left(\mathrm{CaCO}_{3}\right)$, matéria orgânica (M.O.), carbono orgânico total (C.O.T.), valores de diâmetro médio dos grãos do sedimento $(\Phi)$ e a classificação do sedimento proposta por Folk \& Ward (1957) para o estudo piloto do transecto do Flamengo.

\begin{tabular}{c|c|c|c|c|c|c|c|c|c}
\hline $\begin{array}{c}\text { Pontos } \\
\text { amostrais }\end{array}$ & $\begin{array}{c}\mathrm{Gr} . \\
(\%)\end{array}$ & $\begin{array}{c}\text { Ar. } \\
(\%)\end{array}$ & $\begin{array}{c}\text { Sil. } \\
(\%)\end{array}$ & $\begin{array}{c}\text { Arg. } \\
(\%)\end{array}$ & $\begin{array}{c}\mathrm{CaCO}_{3} \\
(\%)\end{array}$ & $\begin{array}{c}\text { M.O. } \\
(\%)\end{array}$ & $\begin{array}{c}\text { C.O.T. } \\
(\%)\end{array}$ & $(\Phi)$ & $\begin{array}{c}\text { Class. } \\
(\text { Folk \& Ward) }\end{array}$ \\
\hline A & 0,00 & 11,87 & 58,68 & 29,44 & 17,40 & 11,54 & 1,76 & 6,51 & silte fino \\
\hline B & 0,96 & 74,48 & 24,55 & 0,00 & 9,20 & 4,60 & 0,35 & 3,91 & areia muito fina \\
\hline C & 5,16 & 54,80 & 31,14 & 8,90 & 35,80 & 7,36 & 1,11 & 3,76 & areia muito fina \\
\hline D & 0,00 & 16,67 & 49,42 & 33,91 & 25,00 & 9,21 & 1,80 & 6,36 & silte fino \\
\hline E & 0,05 & 34,78 & 36,81 & 28,36 & 18,00 & 10,57 & 1,69 & 5,63 & silte médio \\
\hline F & 0,00 & 9,40 & 67,21 & 23,39 & 19,00 & 12,70 & 2,43 & 6,32 & silte fino \\
\hline
\end{tabular}

Os teores de grânulos variaram entre 0,00 e $5,16 \%$, de areia variaram entre 9,40 e $74,48 \%$, de silte variaram entre 24,55 e $67,21 \%$, de argila variaram 
entre 0,00 e 58,68\%, de carbonato de cálcio variaram entre 9,20 e 35,80\%, de matéria orgânica variaram entre 4,6 e 12,70\%, de carbono orgânico total variaram entre 0,35 e $2,43 \%$ e os valores de diâmetros médios do sedimento variaram de 3,76 a 6,91 $\Phi$ entre as amostras (Tab. 3).

A tabela 4 apresenta os valores médios, desvios padrão de clorofila $\underline{a}$, feopigmentos, índices de Margalef e razão $\mathrm{cl}$ a / feo para o transecto do Flamengo. A tabela 5 apresenta os resultados do teste estatístico Kruskal Wallis com a comparação múltipla (do tipo Tukey) de Nemenyi. A tabela 6 apresenta os resultados das correlações de Spearman entre as variáveis avaliadas com nível de significância $(\alpha<0,05)$.

Os resultados apresentados para cada amostra representam a média das 4 réplicas e os resultados apresentados para cada ponto amostral representam a média das 12 réplicas (agrupamento das 3 amostras) coletadas.

Os valores médios dos pigmentos do transecto do Flamengo foram de $15,1 \pm 14,1 \mathrm{mg} \cdot \mathrm{m}^{-2}$ para clorofila a e de $27,5 \pm 26,4 \mathrm{mg} \cdot \mathrm{m}^{-2}$ para o teor de feopigmentos, conforme a tabela 4.

As médias das amostras variaram entre 5,3 (amostra C1) e 41,4 mg.m-2 (amostra A2) para o teor de clorofila a e entre 8,7 (amostra C1) e 87,9 mg.m-2 (amostra D1) para o teor de feopigmentos. Em todas as amostras, os teores de feopigmentos foram superiores aos de clorofila a (Tab. 4 e Fig. 8 a). 
Tabela 4: Valores das médias e dos desvios padrão amostrais para clorofila a $\left(\mathrm{mg} \cdot \mathrm{m}^{-2}\right)$, feopigmentos (mg. $\left.\mathrm{m}^{-2}\right)$, índice de Margalef e razão $\mathrm{cl} \underline{\text { a }}$ / feo para 0 estudo piloto do transecto do Flamengo ( $N_{\text {amostra }}=4 ; \quad N_{\text {ponto }}=12$; $\mathrm{N}_{\text {transecto }}=72$ ).

\begin{tabular}{c|c|c|c|c|c|c|c|c}
\hline & \multicolumn{2}{|c|}{ Clorofila a } & \multicolumn{2}{c|}{ Feopigmentos } & \multicolumn{2}{c|}{ Margalef } & \multicolumn{2}{c}{ Cl a / feo } \\
\hline $\begin{array}{c}\text { Amostras } \\
\text { e Pontos }\end{array}$ & Média & Desvio & Média & Desvio & Média & Desvio & Média & Desvio \\
\hline A1 & 20,4 & 9,3 & 16,1 & 15,9 & 4,3 & 0,4 & 2,0 & 1,6 \\
\hline A2 & 41,4 & 13,4 & 50,9 & 17,3 & 3,6 & 0,2 & 0,8 & 0,1 \\
\hline A3 & 36,7 & 29,3 & 53,0 & 52,2 & 4,1 & 0,7 & 0,8 & 0,3 \\
\hline Ponto A & 32,8 & 19,9 & 40,0 & 34,7 & 4,0 & 0,6 & 1,2 & 1,0 \\
\hline B1 & 13,7 & 3,5 & 13,9 & 7,9 & 3,7 & 0,4 & 1,2 & 0,5 \\
\hline B2 & 15,4 & 2,9 & 20,4 & 12,2 & 3,7 & 0,2 & 1,0 & 0,5 \\
\hline B3 & 13,3 & 5,3 & 16,1 & 10,3 & 3,9 & 0,3 & 1,0 & 0,3 \\
\hline Ponto B & 14,1 & 3,8 & 16,8 & 9,7 & 3,8 & 0,3 & 1,0 & 0,4 \\
\hline C1 & 5,3 & 1,9 & 8,7 & 4,0 & 5,0 & 0,6 & 0,7 & 0,3 \\
\hline C2 & 6,3 & 3,3 & 13,2 & 13,1 & 4,7 & 0,8 & 0,7 & 0,4 \\
\hline C3 & 6,2 & 3,6 & 17,4 & 26,1 & 4,6 & 0,6 & 4,9 & 8,6 \\
\hline Ponto C & 6,0 & 2,8 & 13,1 & 15,8 & 4,8 & 0,6 & 2,1 & 5,0 \\
\hline D1 & 13,2 & 3,7 & 87,9 & 27,9 & 4,0 & 0,3 & 0,2 & 0,1 \\
\hline D2 & 30,0 & 29,6 & 30,1 & 22,8 & 4,8 & 0,4 & 6,1 & 10,0 \\
\hline D3 & 14,0 & 2,7 & 39,6 & 29,3 & 4,7 & 0,5 & 0,6 & 0,4 \\
\hline Ponto D & 19,1 & 17,6 & 52,5 & 35,9 & 4,5 & 0,5 & 2,3 & 5,9 \\
\hline E1 & 11,5 & 3,4 & 30,3 & 11,4 & 5,0 & 0,4 & 0,4 & 0,1 \\
\hline E2 & 11,1 & 1,5 & 27,3 & 16,8 & 4,7 & 0,3 & 0,5 & 0,2 \\
\hline E3 & 10,9 & 2,3 & 22,5 & 5,3 & 4,9 & 0,3 & 0,5 & 0,1 \\
\hline Ponto E & 11,2 & 2,3 & 26,7 & 11,5 & 4,9 & 0,3 & 0,5 & 0,1 \\
\hline F1 & 8,4 & 5,0 & 21,1 & 20,5 & 4,7 & 0,6 & 0,5 & 0,1 \\
\hline F2 & 6,1 & 2,5 & 10,2 & 4,5 & 5,2 & 0,4 & 0,6 & 0,1 \\
\hline F3 & 8,3 & 3,0 & 16,4 & 11,0 & 4,6 & 0,4 & 0,6 & 0,2 \\
\hline Ponto F & 7,6 & 3,5 & 15,9 & 13,3 & 4,8 & 0,5 & 0,6 & 0,1 \\
\hline Transecto & 15,1 & 14,1 & 27,5 & 26,4 & 4,5 & 0,6 & 1,3 & 3,2 \\
\hline & & & & & & & &
\end{tabular}

A média do índice de Margalef foi de 4,5 $\pm 0,6$ e a média da razão de cl a / feo foi de 1,3 $\pm 3,2$. Os índices médios de Margalef variaram entre 3,6 (amostra A2) e 5,2 (amostra F2), enquanto as médias das razões $\mathrm{cl}$ a / feo variaram entre 0,2 (amostra D1) e 6,1 (amostra D2), conforme a tabela 4. 


\section{Transecto do Flamengo}

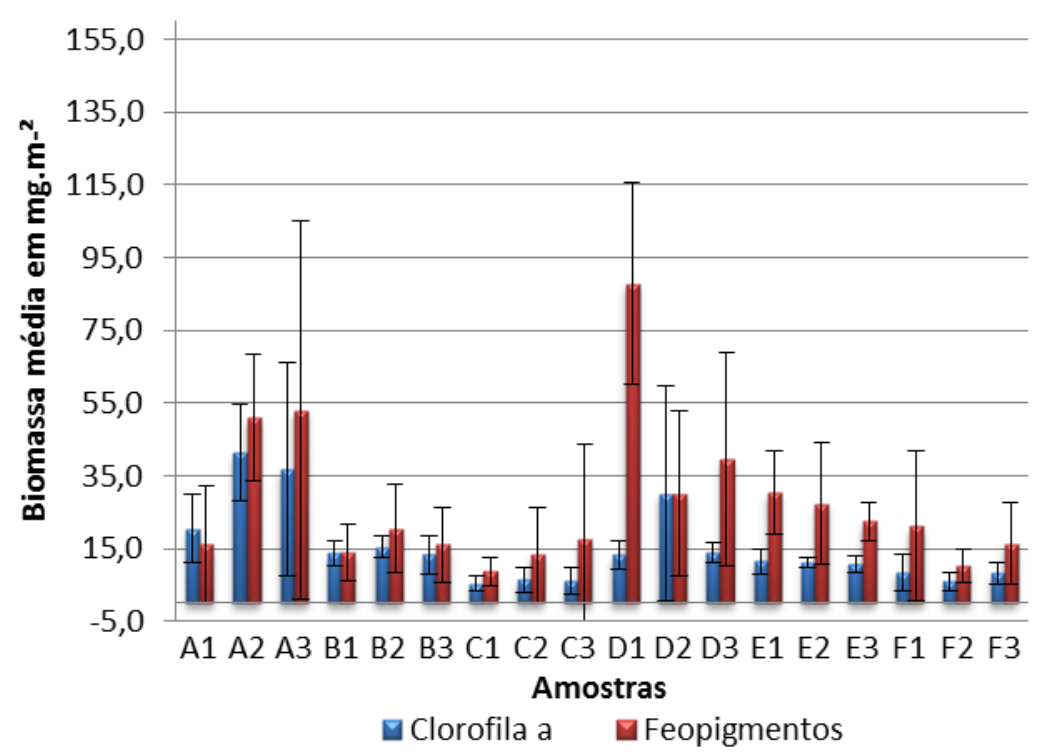

Figura 8 a: Distribuição da biomassa média microfitobentônica por amostras no transecto do Flamengo (estudo piloto).

\section{Transecto do Flamengo}

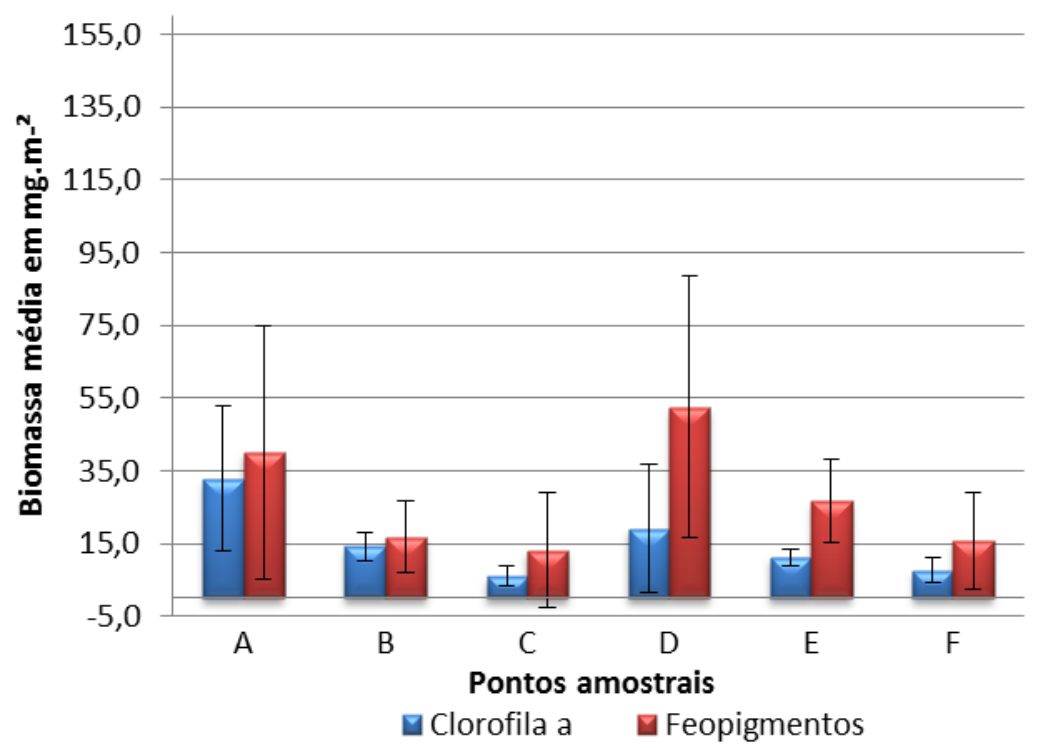

Figura 8 b: Distribuição da biomassa média microfitobentônica por pontos amostrais no transecto do Flamengo (estudo piloto).

Ao comparar a distribuição da biomassa do microfitobentos para 0 estudo piloto do transecto do Flamengo (Tab. 5 e Fig. 8 b), o teste estatístico considerou os pontos amostrais significativamente diferentes $(\alpha<0,05)$ para clorofila $\underline{\text { a }}(p=0,0000)$ e para feopigmentos $(p=0,0007)$. 
A comparação múltipla para os pontos amostrais do transecto do Flamengo formou dois grupos distintos para clorofila a: o grupo de maior biomassa foi formado pelos pontos amostrais $A, D$ e $B$, sem associação com 0 grupo de menor biomassa; enquanto o grupo de menor biomassa foi formado pelos pontos amostrais C, F e E. Para feopigmentos, foram formados três grupos distintos: os pontos amostrais D e A formaram o grupo de maior teor, mas associado com os pontos amostrais $E$ e $B$; o grupo de menor teor foi formado pelos pontos amostrais $C$ e $F$, mas associado com os pontos amostrais $\mathrm{B}$ e $\mathrm{E}$; e o grupo de teor intermediário foi formado pelos pontos amostrais B e E, mas associado com os demais grupos (Tab. 5).

Tabela 5: Resultados do Teste de Kruskal-Wallis $(\alpha<0,05)$, com a comparação múltipla (do tipo Tukey) de Nemenyi para o estudo piloto do transecto do Flamengo.

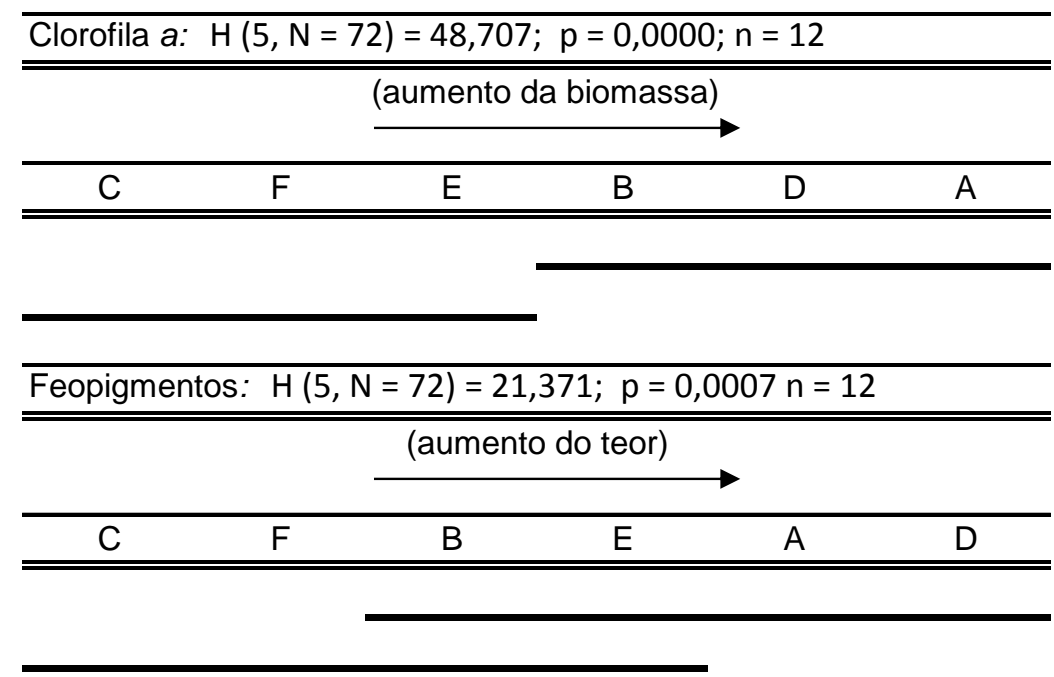

Clorofila a e feopigmentos apresentaram uma correlação positiva. A clorofila a também se correlacionou positivamente com irradiância no sedimento, diâmetro médio dos grãos do sedimento e argila, enquanto se correlacionou negativamente com salinidade, grânulos e profundidade, conforme a tabela 6.

Feopigmentos se correlacionaram positivamente com diâmetro médio dos grãos do sedimento e com argila, enquanto se correlacionaram negativamente com grânulos, conforme a tabela 6 . 
O índice de Margalef se correlacionou negativamente com irradiância no sedimento e temperatura, enquanto se correlacionou positivamente com profundidade, salinidade, carbonato de cálcio, carbono orgânico total e matéria orgânica, conforme a tabela 6.

A razão $\mathrm{cl} \underline{\mathrm{a}}$ / feo se correlacionou negativamente com profundidade e salinidade, enquanto se correlacionou positivamente com irradiância no sedimento, conforme a tabela 6 .

Tabela 6: Correlações $(N=72)$ de Spearman $(r)$, entre as variáveis avaliadas para o estudo piloto do transecto do Flamengo.

\begin{tabular}{c|c|c}
\hline Variáveis & Spearman & p-nível \\
\hline Clorofila a X Feopigmentos & 0,612 & 0,000000 \\
\hline Clorofila a X Profundidade & $-0,509$ & 0,000005 \\
\hline Clorofila a X Irradiância no sedimento & 0,437 & 0,000124 \\
\hline Clorofila a X Salinidade & $-0,559$ & 0,000000 \\
\hline Clorofila a X Diâmetro médio dos grãos do sedimento & 0,574 & 0,000000 \\
\hline Clorofila a X Grânulos & $-0,390$ & 0,000697 \\
\hline Clorofila a X Argila & 0,496 & 0,000009 \\
\hline Feopigmentos X Diâmetro médio dos grãos do sedimento & 0,412 & 0,000318 \\
\hline Feopigmentos X Grânulos & $-0,343$ & 0,003141 \\
\hline Feopigmentos X Argila & 0,447 & 0,000082 \\
\hline Margalef X Profundidade & 0,543 & 0,000001 \\
\hline Margalef X Irradiância no sedimento & $-0,550$ & 0,000000 \\
\hline Margalef X Salinidade & 0,326 & 0,005144 \\
\hline Margalef X Temperatura & $-0,311$ & 0,007736 \\
\hline Margalef X Carbonato de cálcio & 0,493 & 0,000011 \\
\hline Margalef X Carbono orgânico total & 0,247 & 0,036528 \\
\hline Margalef X Matéria orgânica & 0,244 & 0,039051 \\
\hline Cl a / Feo X Profundidade & $-0,513$ & 0,000004 \\
\hline Cl a / Feo X Irradiância no sedimento & 0,553 & 0,000000 \\
\hline Cl a / Feo X Salinidade & $-0,341$ & 0,003405 \\
\hline
\end{tabular}

\section{1. 2. Transecto da Fortaleza}

A tabela 7 apresenta os resultados ambientais, tais como profundidade dos pontos de coleta, profundidade de desaparecimento do disco de Secchi, temperatura, salinidade, coeficiente de luz e irradiância no sedimento. 
Tabela 7: Valores de profundidade (prof.), profundidade de desaparecimento do disco de Secchi (Secchi), temperatura $\left(\mathrm{T}^{\circ} \mathrm{\circ} \mathrm{C}\right)$, salinidade $(\mathrm{S})$, coeficiente de extinção de luz $(\mathrm{K})$ e irradiância no sedimento $\left(\mathrm{I}_{(\mathrm{z})}\right)$ para o estudo piloto do transecto da Fortaleza.

\begin{tabular}{c|c|c|c|c|c|c}
\hline $\begin{array}{c}\text { Pontos } \\
\text { amostrais }\end{array}$ & Prof. & Secchi & $\mathrm{T}^{\circ} \mathrm{C}$ & $\mathrm{S}$ & $\mathrm{K}$ & $\mathrm{I}_{(\mathrm{z})}(\%)$ \\
\hline A & 5 & 4,0 & 19,33 & 37,00 & 0,425 & 11,946 \\
\hline $\mathrm{B}$ & 10 & 6,0 & 15,70 & 37,00 & 0,283 & 5,883 \\
\hline C & 15 & 6,0 & 15,30 & 37,00 & 0,283 & 1,427 \\
\hline $\mathrm{D}$ & 20 & 8,0 & 14,90 & 37,00 & 0,213 & 1,427 \\
\hline $\mathrm{E}$ & 25 & 6,0 & 15,05 & 37,00 & 0,283 & 0,084 \\
\hline F & 30 & 6,0 & 14,95 & 37,00 & 0,283 & 0,020 \\
\hline
\end{tabular}

A profundidade de desaparecimento do disco de Secchi variou entre 4,0 e 8,0 metros, a temperatura variou entre 14,90 e 19,33 ${ }^{\circ} \mathrm{C}$, a salinidade foi 37 em todas as amostras, o coeficiente de extinção de luz variou entre 0,213 e 0,425 e a irradiância no sedimento variou entre 0,020 e 11,946\% (Tab. 7).

A tabela 8 apresenta os teores granulométricos, teores de carbonato de cálcio, de matéria orgânica e de carbono orgânico total, valores de diâmetro médio dos grãos do sedimento e a classificação do sedimento.

Tabela 8: Teores de grânulos (Gr.), areia (Ar.), silte (Sil.), argila (Arg.), carbonato de cálcio $\left(\mathrm{CaCO}_{3}\right)$, matéria orgânica (M.O.), carbono orgânico total (C.O.T.), valores de diâmetro médio dos grãos do sedimento (Ф) e a classificação do sedimento proposta por Folk \& Ward (1957) para o estudo piloto do transecto da Fortaleza.

\begin{tabular}{c|c|c|c|c|c|c|c|c|c}
\hline $\begin{array}{c}\text { Pontos } \\
\text { amostrais }\end{array}$ & $\begin{array}{c}\text { Gr. } \\
(\%)\end{array}$ & $\begin{array}{c}\text { Ar. } \\
(\%)\end{array}$ & $\begin{array}{c}\text { Sil. } \\
(\%)\end{array}$ & $\begin{array}{c}\text { Arg. } \\
(\%)\end{array}$ & $\begin{array}{c}\mathrm{CaCO}_{3} \\
(\%)\end{array}$ & $\begin{array}{c}\text { M.O. } \\
(\%)\end{array}$ & $\begin{array}{c}\text { C.O.T. } \\
(\%)\end{array}$ & $(\Phi)$ & $\begin{array}{c}\text { Class. } \\
(\text { Folk \& Ward) }\end{array}$ \\
\hline A & 12,35 & 17,39 & 56,65 & 13,62 & 26,60 & 8,55 & 1,16 & 4,06 & silte grosso \\
\hline B & 0,32 & 23,06 & 65,26 & 11,37 & 19,70 & 8,45 & 0,98 & 5,18 & silte médio \\
\hline C & 0,00 & 18,69 & 75,12 & 6,19 & 14,30 & 3,22 & 0,34 & 4,51 & silte grosso \\
\hline D & 0,45 & 45,64 & 44,97 & 8,95 & 17,40 & 6,47 & 0,90 & 4,51 & silte grosso \\
\hline E & 0,04 & 46,33 & 34,32 & 19,31 & 15,90 & 7,89 & 1,29 & 5,11 & silte médio \\
\hline F & 7,02 & 92,98 & 0,00 & 0,00 & 20,30 & 1,34 & 0,07 & 0,71 & areia grossa \\
\hline
\end{tabular}

Os teores de grânulos variaram entre 0,00 e 12,35\%, de areia variaram entre 18,69 e $92,98 \%$, de silte variaram entre 0,00 e $75,12 \%$, de argila variaram 
entre 0,00 e 19,31\%, de carbonato de cálcio variaram entre 14,30 e 26,60\%, de matéria orgânica variaram entre 1,34 e $8,55 \%$, de carbono orgânico total variaram entre 0,07 e $1,29 \%$ e os valores de diâmetros médios do sedimento variaram de 0,71 a 5,18 $\Phi$ entre as amostras (Tab. 8).

A tabela 9 apresenta os valores médios, desvios padrão de clorofila $\underline{a}$, feopigmentos, índices de Margalef e razão $\mathrm{cl}$ a / feo para o transecto da Fortaleza. A tabela 10 apresenta os resultados do teste estatístico Kruskal Wallis e a comparação múltipla (do tipo Tukey) de Nemenyi. A tabela 11 apresenta os resultados das correlações de Spearman entre as variáveis avaliadas com nível de significância $(\alpha<0,05)$.

Os valores médios dos pigmentos do transecto da Fortaleza foram de $10,4 \pm 17,1 \mathrm{mg} \cdot \mathrm{m}^{-2}$ para clorofila a e de 17,0 $\pm 41,3 \mathrm{mg} \cdot \mathrm{m}^{-2}$ para feopigmentos, conforme a tabela 9.

As médias das amostras variaram entre 3,6 (amostra B1) e 44,4 mg.m-2 (amostra A2) para a biomassa de clorofila a e entre 1,8 (amostra B1) e 94,6 mg.m-2 (amostra A2) para o teor de feopigmentos. Em quase todas as amostras, os valores de feopigmentos foram superiores aos de clorofila $\underline{a}$, com exceção das amostras A1, B1, B2 e B3, conforme a tabela 9 e a figura 9 a.

Observando a tabela 9 e a figura 9 b, é possível notar uma grande diferença $\left(32,9 \mathrm{mg}^{\mathrm{m}} \mathrm{-}^{2}\right)$ do teor de clorofila a do ponto amostral A (5 metros de profundidade) em relação aos demais pontos amostrais, mas entre os demais pontos amostrais ( $B, C, D, E$ e $F$ ), ocorreu um valor médio entre 4,3 e 7,1 $\mathrm{mg} \cdot \mathrm{m}^{2}$. Para feopigmentos, os teores médios variaram um pouco mais entre os pontos amostrais, sendo $51,7 \mathrm{mg} \cdot \mathrm{m}^{-2}$ para o ponto amostral A e 2,6 mg.m-2 para o ponto amostral $B$ (10 metros de profundidade), e uma variação menor entre os pontos amostrais C, D, E e F (entre 10,0 e 15,2 mg.m-2).

A média do índice de Margalef foi de $4,3 \pm 0,8$ e a média da razão $\mathrm{cl} \underline{\text { a }}$ / feo foi de $1,4 \pm 2,1$. Os índices médios de Margalef variaram entre 3,5 (amostras C1 e F1) e 5,5 (amostra E3), enquanto as médias das razões cl a / feo variaram entre 0,4 (amostra E1) e 4,7 (amostra B3), conforme a tabela 9. 
Tabela 9: Valores das médias e dos desvios padrão amostrais para clorofila $\underline{a}\left(\mathrm{mg} \cdot \mathrm{m}^{-2}\right)$, feopigmentos $\left(\mathrm{mg} \cdot \mathrm{m}^{-2}\right)$, índice de Margalef e razão $\mathrm{cl}$ a $/$ feo para o estudo piloto do transecto da Fortaleza $\left(\mathrm{N}_{\text {amostra }}=4 ; \mathrm{N}_{\text {ponto }}=12 ; \mathrm{N}_{\text {transecto }}=72\right)$.

\begin{tabular}{c|c|c|c|c|c|c|c|c}
\hline & \multicolumn{2}{|c|}{ Clorofila } & \multicolumn{2}{c|}{ Feopigmentos } & \multicolumn{2}{c|}{ Margalef } & \multicolumn{2}{c}{ Cl $\underline{\text { a }}$ feo } \\
\hline $\begin{array}{c}\text { Amostras } \\
\text { e Pontos }\end{array}$ & Média & Desvio & Média & Desvio & Média & Desvio & Média & Desvio \\
\hline A1 & 22,0 & 11,6 & 21,1 & 15,9 & 4,5 & 0,4 & 1,2 & 0,3 \\
\hline A2 & 44,4 & 56,8 & 94,6 & 162,6 & 4,4 & 1,0 & 1,5 & 1,1 \\
\hline A3 & 32,3 & 24,5 & 39,3 & 40,4 & 4,6 & 0,6 & 1,1 & 0,4 \\
\hline Ponto A & 32,9 & 34,2 & 51,7 & 93,7 & 4,5 & 0,6 & 1,2 & 0,6 \\
\hline B1 & 3,6 & 2,3 & 1,8 & 1,8 & 4,2 & 1,1 & 2,8 & 1,0 \\
\hline B2 & 4,8 & 3,8 & 4,0 & 4,2 & 4,0 & 0,3 & 1,7 & 0,8 \\
\hline B3 & 4,6 & 3,2 & 2,0 & 2,1 & 4,5 & 0,7 & 4,7 & 6,4 \\
\hline Ponto B & 4,3 & 2,9 & 2,6 & 2,8 & 4,2 & 0,7 & 3,1 & 3,6 \\
\hline C1 & 5,6 & 1,7 & 9,0 & 6,2 & 3,5 & 0,1 & 0,7 & 0,2 \\
\hline C2 & 7,5 & 2,0 & 10,2 & 7,6 & 3,6 & 0,2 & 1,0 & 0,5 \\
\hline C3 & 8,2 & 2,0 & 10,7 & 7,8 & 3,6 & 0,3 & 0,9 & 0,3 \\
\hline Ponto C & 7,1 & 2,1 & 10,0 & 6,6 & 3,6 & 0,2 & 0,9 & 0,3 \\
\hline D1 & 6,4 & 3,4 & 8,5 & 6,9 & 4,7 & 0,3 & 0,9 & 0,4 \\
\hline D2 & 5,4 & 1,7 & 8,5 & 3,0 & 4,7 & 0,5 & 0,7 & 0,3 \\
\hline D3 & 6,6 & 2,0 & 13,2 & 13,1 & 4,4 & 0,6 & 0,8 & 0,5 \\
\hline Ponto D & 6,1 & 2,3 & 10,0 & 8,2 & 4,6 & 0,5 & 0,8 & 0,4 \\
\hline E1 & 5,1 & 1,8 & 14,4 & 9,3 & 4,8 & 0,9 & 0,4 & 0,2 \\
\hline E2 & 4,6 & 1,3 & 9,4 & 5,0 & 5,2 & 0,5 & 0,6 & 0,3 \\
\hline E3 & 7,0 & 3,8 & 13,1 & 13,9 & 5,5 & 0,6 & 0,7 & 0,2 \\
\hline Ponto E & 5,6 & 2,5 & 12,3 & 9,4 & 5,1 & 0,7 & 0,6 & 0,3 \\
\hline F1 & 6,9 & 5,1 & 17,7 & 18,2 & 3,5 & 0,1 & 3,3 & 5,6 \\
\hline F2 & 6,4 & 2,6 & 11,8 & 8,7 & 3,8 & 0,2 & 1,2 & 1,3 \\
\hline F3 & 5,6 & 4,7 & 16,3 & 29,0 & 3,9 & 0,4 & 1,6 & 1,0 \\
\hline Ponto F & 6,3 & 3,9 & 15,2 & 18,6 & 3,7 & 0,3 & 2,0 & 3,2 \\
\hline Transecto & 10,4 & 17,1 & 17,0 & 41,3 & 4,3 & 0,8 & 1,4 & 2,1 \\
\hline & & & & & & & &
\end{tabular}




\section{Transecto da Fortaleza}

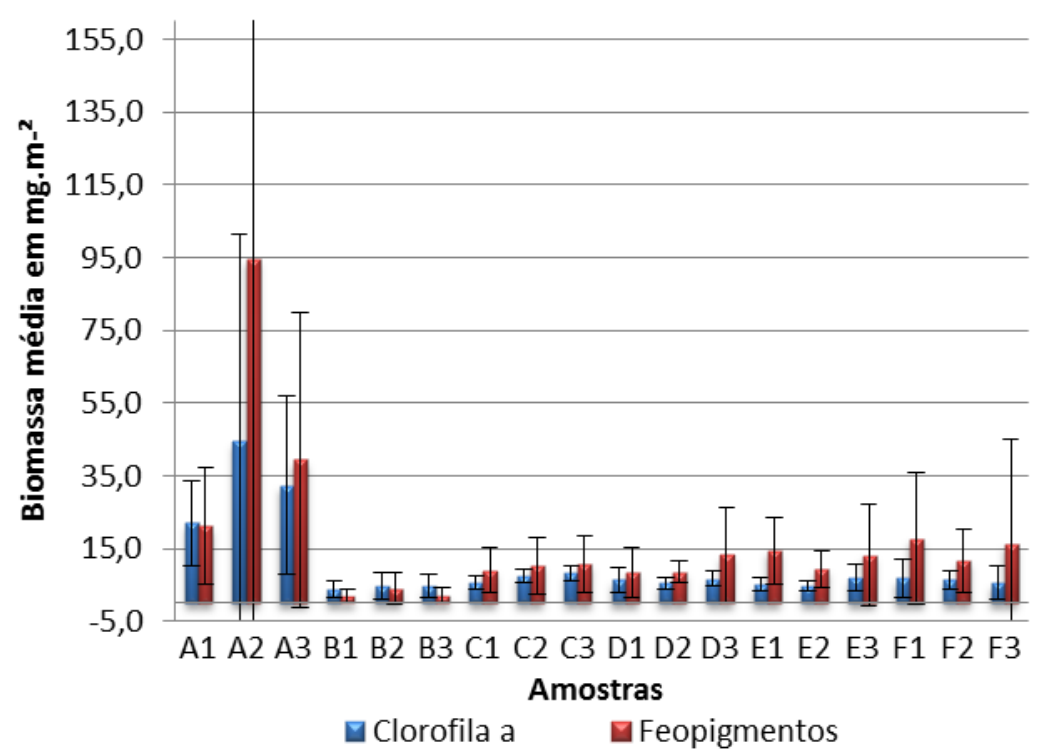

Figura 9 a: Distribuição da biomassa média microfitobentônica por amostras no transecto da Fortaleza (estudo piloto).

\section{Transecto da Fortaleza}

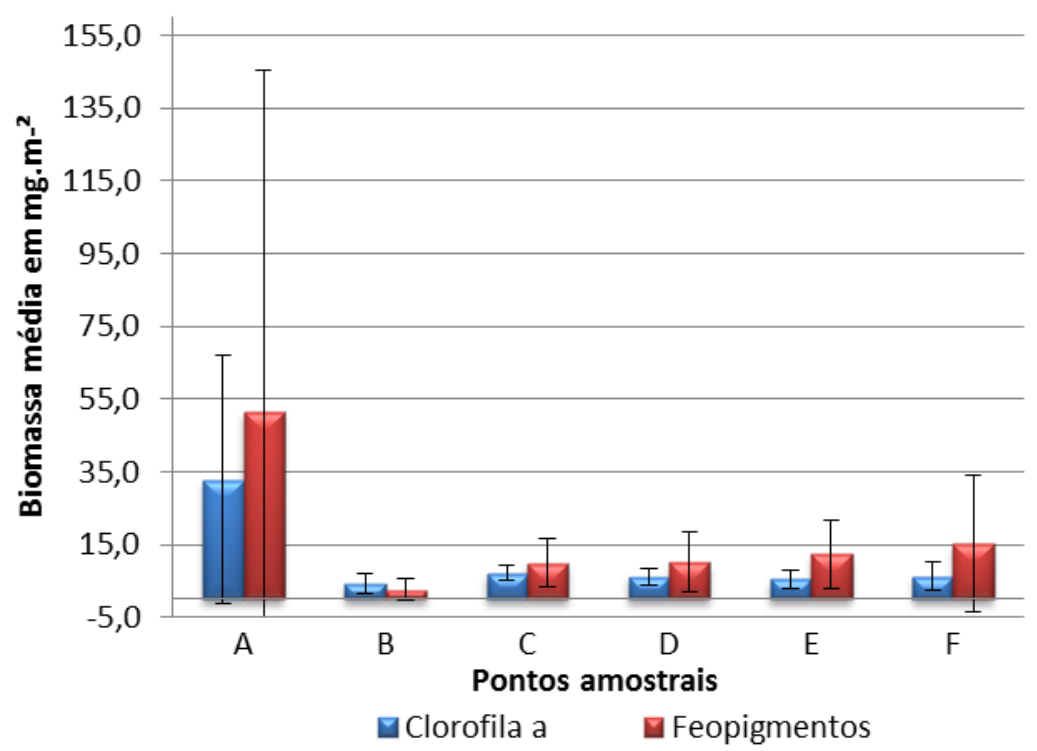

Figura 9 b: Distribuição da biomassa média microfitobentônica por pontos amostrais no transecto da Fortaleza (estudo piloto).

Ao comparar a distribuição da biomassa do microfitobentos para o estudo piloto do transecto da Fortaleza (Tab. 10 e Fig. 9 b), o teste estatístico 
considerou os pontos amostrais significativamente diferentes para clorofila $\underline{a}$ ( $p$ $=0,0002)$ e para feopigmentos $(p=0,0010)$.

A comparação múltipla para os pontos amostrais do transecto da Fortaleza formou três grupos distintos para clorofila a: onde o grupo de maior biomassa foi formado apenas pelo ponto amostral $A$, mas associado com 0 ponto amostral C; os pontos amostrais B, E, F e D formaram o grupo de menor biomassa, mas associado com o ponto amostral C; e o ponto amostral C formou o grupo de biomassa intermediária, mas associado com os demais grupos. Para feopigmentos também foram formados três grupos distintos: o grupo de maior teor foi formado pelos pontos amostrais $A, E, C, D$, mas associado com o ponto amostral F; o grupo de menor teor foi formado apenas pelo ponto amostral $\mathrm{B}$, mas associado com o ponto amostral F; e o grupo de teor intermediário foi formado apenas pelo ponto amostral F, mas associado com os demais grupos (Tab. 10).

Tabela 10: Resultados do Teste de Kruskal-Wallis $(\alpha<0,05)$, com a comparação múltipla (do tipo Tukey) de Nemenyi para o estudo piloto do transecto da Fortaleza.

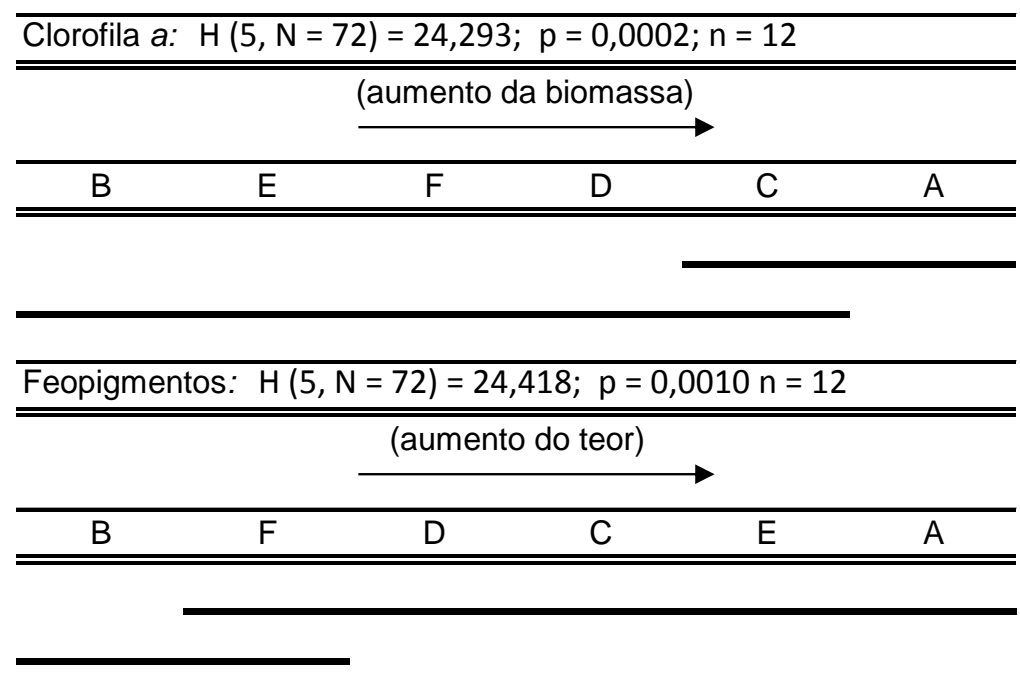

Clorofila a apresentou uma forte correlação positiva com feopigmentos, e também se correlacionou positivamente com irradiância no sedimento e temperatura, enquanto se correlacionou negativamente com profundidade e areia, conforme a tabela 11. 
O índice de Margalef se correlacionou positivamente com carbono orgânico total, matéria orgânica, diâmetro médio dos grãos do sedimento e argila, enquanto se correlacionou negativamente com silte, conforme a tabela 11.

A razão $\mathrm{cl} \underline{\text { a } ~ / ~ f e o ~ s e ~ c o r r e l a c i o n o u ~ p o s i t i v a m e n t e ~ c o m ~ i r r a d i a ̂ n c i a ~ n o ~}$ sedimento, temperatura, carbonato de cálcio, matéria orgânica e silte, enquanto se correlacionou negativamente com profundidade e areia, conforme a tabela 11.

Tabela 11: Correlações $(N=72)$ de Spearman $(r)$, entre as variáveis avaliadas para o estudo piloto do transecto da Fortaleza.

\begin{tabular}{c|c|c}
\hline Variáveis & Spearman & p-nível \\
\hline Clorofila a X Feopigmentos & 0,808 & 0,000000 \\
\hline Clorofila a X Profundidade & $-0,286$ & 0,014856 \\
\hline Clorofila a X Irradiância no sedimento & 0,295 & 0,011751 \\
\hline Clorofila a X Temperatura & 0,254 & 0,031346 \\
\hline Clorofila a X Areia & $-0,376$ & 0,001132 \\
\hline Margalef X Carbono orgânico total & 0,609 & 0,000000 \\
\hline Margalef X Matéria orgânica & 0,437 & 0,000125 \\
\hline Margalef X Diâmetro médio dos grãos do sedimento & 0,272 & 0,020831 \\
\hline Margalef X Silte & $-0,244$ & 0,038728 \\
\hline Margalef X Argila & 0,609 & 0,000000 \\
\hline $\mathrm{Cl} \underline{\text { a } / \text { Feo e Profundidade }}$ & $-0,399$ & 0,000522 \\
\hline $\mathrm{Cl}$ a / Feo X Irradiância no sedimento & 0,466 & 0,000038 \\
\hline $\mathrm{Cl}$ / Feo X Temperatura & 0,367 & 0,001516 \\
\hline $\mathrm{Cl}$ a Feo X Carbonato de cálcio & 0,294 & 0,012225 \\
\hline $\mathrm{Cl}$ / Feo X Matéria orgânica & 0,274 & 0,019712 \\
\hline $\mathrm{Cl}$ a / Feo X Areia & $-0,275$ & 0,019351 \\
\hline Cl a / Feo X Silte & 0,299 & 0,010849 \\
\hline
\end{tabular}

\section{1. 3. Transecto do Mar Virado}

A tabela 12 apresenta os resultados ambientais, tais como profundidade dos pontos de coleta, profundidade de desaparecimento do disco de Secchi, temperatura, salinidade, coeficiente de luz e irradiância no sedimento. 
Tabela 12: Valores de profundidade (prof.), profundidade de desaparecimento do disco de Secchi (Secchi), temperatura $\left(\mathrm{T}^{\circ} \mathrm{\circ} \mathrm{C}\right)$, salinidade $(\mathrm{S})$, coeficiente de extinção de luz $(\mathrm{K})$ e irradiância no sedimento $\left(\mathrm{I}_{(\mathrm{z})}\right)$ para o estudo piloto do transecto do Mar Virado.

\begin{tabular}{c|c|c|c|c|c|c}
\hline $\begin{array}{c}\text { Pontos } \\
\text { amostrais }\end{array}$ & Prof. & Secchi & $\mathrm{T} \stackrel{\circ}{ } \mathrm{C}$ & $\mathrm{S}$ & $\mathrm{K}$ & $\mathrm{I}_{(\mathrm{z})}(\%)$ \\
\hline A & 5 & 3,5 & 27,55 & 37,00 & 0,486 & 8,818 \\
\hline $\mathrm{B}$ & 10 & 4,0 & 27,30 & 37,00 & 0,425 & 1,427 \\
\hline C & 15 & 4,0 & 27,70 & 37,00 & 0,425 & 0,170 \\
\hline D & 20 & 5,0 & 27,95 & 37,00 & 0,340 & 0,111 \\
\hline E & 25 & 6,0 & 27,40 & 37,00 & 0,283 & 0,084 \\
\hline F & 30 & 6,0 & 26,10 & 37,00 & 0,283 & 0,020 \\
\hline
\end{tabular}

A profundidade de desaparecimento do disco de Secchi variou entre 3,5 e 6,0 metros, a temperatura variou entre 26,10 e $27,95{ }^{\circ} \mathrm{C}$, a salinidade foi $37 \mathrm{em}$ todas as amostras, o coeficiente de extinção de luz variou entre 0,283 e 0,486 e a irradiância no sedimento variou entre 0,020 e 8,818\% (Tab. 12).

A tabela 13 apresenta os teores granulométricos, teores de carbonato de cálcio, de matéria orgânica e de carbono orgânico total, valores de diâmetro médio dos grãos do sedimento e a classificação do sedimento.

Tabela 13: Teores de grânulos (Gr.), areia (Ar.), silte (Sil.), argila (Arg.), carbonato de cálcio $\left(\mathrm{CaCO}_{3}\right)$, matéria orgânica (M.O.), carbono orgânico total (C.O.T.), valores de diâmetro médio dos grãos do sedimento (Ф) e a classificação do sedimento proposta por Folk \& Ward (1957) para o estudo piloto do transecto do Mar Virado.

\begin{tabular}{c|c|c|c|c|c|c|c|c|c}
\hline $\begin{array}{c}\text { Pontos } \\
\text { amostrais }\end{array}$ & $\begin{array}{c}\text { Gr. } \\
(\%)\end{array}$ & $\begin{array}{c}\text { Ar. } \\
(\%)\end{array}$ & $\begin{array}{c}\text { Sil. } \\
(\%)\end{array}$ & $\begin{array}{c}\text { Arg. } \\
(\%)\end{array}$ & $\begin{array}{c}\mathrm{CaCO}_{3} \\
(\%)\end{array}$ & $\begin{array}{c}\text { M.O. } \\
(\%)\end{array}$ & $\begin{array}{c}\text { C.O.T. } \\
(\%)\end{array}$ & $(\Phi)$ & $\begin{array}{c}\text { Class. } \\
(\text { Folk \& Ward) }\end{array}$ \\
\hline A & 5,34 & 67,06 & 23,22 & 4,38 & 19,00 & 4,21 & 0,38 & 3,51 & areia muito fina \\
\hline B & 0,00 & 6,89 & 88,70 & 4,33 & 17,80 & 4,21 & 0,49 & 4,59 & silte grosso \\
\hline C & 0,00 & 6,17 & 82,65 & 11,18 & 20,10 & 6,61 & 0,87 & 5,28 & silte médio \\
\hline D & 0,00 & 5,53 & 80,97 & 13,50 & 21,30 & 9,89 & 1,39 & 5,80 & silte médio \\
\hline E & 1,67 & 81,65 & 10,43 & 6,26 & 14,40 & 4,43 & 0,54 & 3,22 & areia muito fina \\
\hline F & 2,57 & 76,61 & 10,31 & 10,52 & 17,00 & 5,17 & 0,64 & 4,14 & silte grosso \\
\hline
\end{tabular}

Os teores de grânulos variaram entre 0,00 e 5,34\%, de areia variaram entre 5,53 e $81,65 \%$, de silte variaram entre 10,31 e $88,7 \%$, de argila variaram entre 4,33 e 13,50\%, de carbonato de cálcio variaram entre 14,40 e $21,30 \%$, 
de matéria orgânica variaram entre 4,21 e 9,89\%, de carbono orgânico total variaram entre 0,38 e 1,39\% e os valores de diâmetros médios do sedimento variaram de 3,22 a 5,80 $\Phi$ entre as amostras (Tab. 13).

A tabela 14 apresenta os valores médios, desvios padrão de clorofila $\underline{a}$, feopigmentos, índices de Margalef e razão cl a / feo para o transecto do Mar Virado. A tabela 15 apresenta os resultados do teste estatístico Kruskal - Wallis com a comparação múltipla (do tipo Tukey) de Nemenyi. A tabela 16 apresenta os resultados das correlações de Spearman entre as variáveis avaliadas com nível de significância $(\alpha<0,05)$.

Os valores médios dos pigmentos do transecto do Mar Virado foram de $6,8 \pm 3,4 \mathrm{mg} \cdot \mathrm{m}^{-2}$ para clorofila a e de $9,6 \pm 11,8 \mathrm{mg} \cdot \mathrm{m}^{-2}$ para feopigmentos, conforme a tabela 14 .

As médias das amostras variaram entre 4,2 (amostra C1) e 11,3 mg.m-2 (amostra A2) para clorofila a e entre 3,5 (amostra E3) e 36,3 mg.m-2 (amostra F2) para feopigmentos (Tab. 14 e Fig. 10 a).

A média do índice de Margalef foi de 4,4 $\pm 0,7$ e a média da razão de cl a / feo foi de $1,1 \pm 0,7$. Os índices médios de Margalef variaram entre 3,7 (amostras C1 e C3) e 5,4 (amostra E1), enquanto as médias das razões $\mathrm{cl}$ a / feo variaram entre 0,4 (amostras C1 e F2) e 2,4 (amostra A2), conforme a tabela 14. 
Tabela 14: Valores das médias e dos desvios padrão amostrais para clorofila a $\left(\mathrm{mg} \cdot \mathrm{m}^{-2}\right)$, feopigmentos (mg. $\left.\mathrm{m}^{-2}\right)$, índice de Margalef e razão $\mathrm{cl} \underline{\text { a }}$ / feo para o estudo piloto do transecto do Mar Virado ( $N_{\text {amostra }}=4 ; N_{\text {ponto }}=12$; $\mathrm{N}_{\text {transecto }}=72$ ).

\begin{tabular}{c|c|c|c|c|c|c|c|c}
\hline & \multicolumn{2}{|c|}{ Clorofila $\underline{\text { a }}$} & \multicolumn{2}{c|}{ Feopigmentos } & \multicolumn{2}{c|}{ Margalef } & \multicolumn{2}{c}{ Cl a feo } \\
\hline $\begin{array}{c}\text { Amostras } \\
\text { e Pontos }\end{array}$ & Média & Desvio & Média & Desvio & Média & Desvio & Média & Desvio \\
\hline A1 & 8,9 & 3,2 & 4,8 & 1,2 & 4,2 & 0,8 & 1,8 & 0,3 \\
\hline A2 & 11,3 & 4,5 & 4,9 & 2,4 & 4,3 & 0,9 & 2,4 & 0,3 \\
\hline A3 & 8,9 & 3,5 & 6,2 & 3,0 & 4,7 & 0,4 & 1,6 & 0,4 \\
\hline Ponto A & 9,7 & 3,6 & 5,3 & 2,2 & 4,4 & 0,7 & 1,9 & 0,5 \\
\hline B1 & 7,1 & 6,1 & 8,7 & 9,9 & 4,0 & 0,6 & 1,3 & 0,7 \\
\hline B2 & 4,9 & 1,6 & 3,6 & 2,4 & 4,2 & 0,3 & 1,6 & 0,7 \\
\hline B3 & 6,3 & 3,0 & 5,0 & 5,3 & 4,1 & 0,5 & 1,9 & 0,8 \\
\hline Ponto B & 6,1 & 3,8 & 5,7 & 6,4 & 4,1 & 0,5 & 1,6 & 0,7 \\
\hline C1 & 4,2 & 3,1 & 14,1 & 12,9 & 3,7 & 0,3 & 0,4 & 0,1 \\
\hline C2 & 7,1 & 4,6 & 12,3 & 8,2 & 3,9 & 0,1 & 0,6 & 0,1 \\
\hline C3 & 7,0 & 1,8 & 10,9 & 4,3 & 3,7 & 0,1 & 0,7 & 0,2 \\
\hline Ponto C & 6,1 & 3,3 & 12,4 & 8,4 & 3,8 & 0,2 & 0,5 & 0,2 \\
\hline D1 & 6,3 & 1,7 & 5,4 & 1,8 & 4,6 & 0,3 & 1,2 & 0,2 \\
\hline D2 & 5,5 & 1,5 & 4,8 & 0,9 & 4,6 & 0,2 & 1,2 & 0,3 \\
\hline D3 & 6,7 & 1,9 & 8,2 & 4,6 & 4,5 & 0,4 & 1,0 & 0,3 \\
\hline Ponto D & 6,2 & 1,6 & 6,1 & 3,1 & 4,6 & 0,3 & 1,1 & 0,3 \\
\hline E1 & 5,4 & 1,8 & 5,8 & 2,3 & 5,4 & 0,4 & 1,1 & 0,7 \\
\hline E2 & 4,4 & 3,6 & 8,6 & 10,7 & 5,2 & 0,4 & 0,7 & 0,3 \\
\hline E3 & 4,3 & 1,5 & 3,5 & 2,1 & 4,7 & 0,8 & 1,5 & 0,8 \\
\hline Ponto E & 4,7 & 2,3 & 6,0 & 6,2 & 5,1 & 0,6 & 1,1 & 0,6 \\
\hline F1 & 6,7 & 3,3 & 16,1 & 12,8 & 5,0 & 0,3 & 0,5 & 0,2 \\
\hline F2 & 10,5 & 4,7 & 36,3 & 34,8 & 4,5 & 0,6 & 0,4 & 0,2 \\
\hline F3 & 6,4 & 0,8 & 13,6 & 6,1 & 4,6 & 0,8 & 0,5 & 0,2 \\
\hline Ponto F & 7,9 & 3,6 & 22,0 & 22,3 & 4,7 & 0,6 & 0,5 & 0,2 \\
\hline Transecto & 6,8 & 3,4 & 9,6 & 11,8 & 4,4 & 0,7 & 1,1 & 0,7 \\
\hline
\end{tabular}




\section{Transecto do Mar Virado}

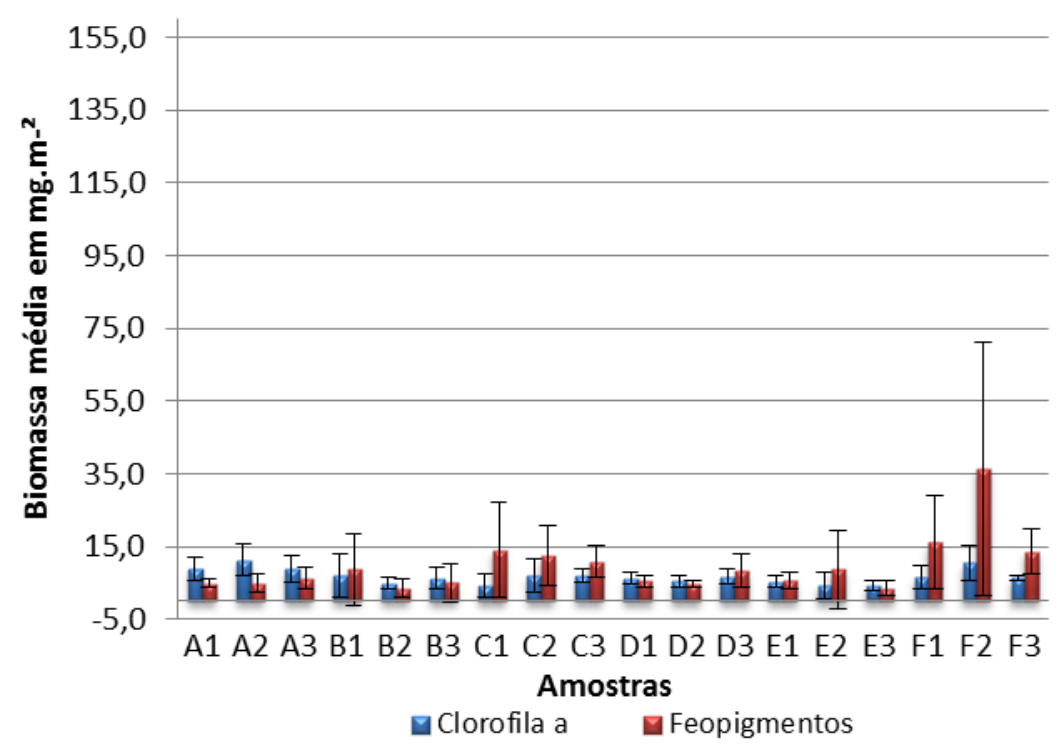

Figura 10 a: Distribuição da biomassa média microfitobentônica por amostras no transecto do Mar Virado (estudo piloto).

\section{Transecto do Mar Virado}

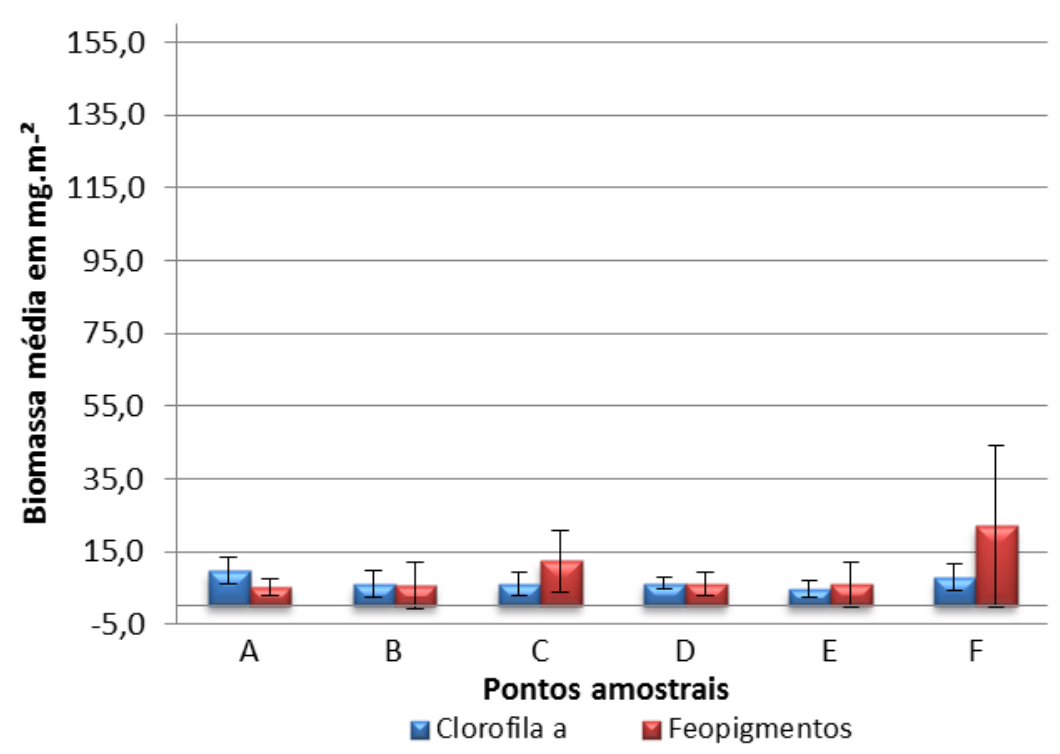

Figura 10 b: Distribuição da biomassa média microfitobentônica por pontos amostrais no transecto do Mar Virado (estudo piloto).

Ao comparar a distribuição da biomassa do microfitobentos para 0 estudo piloto do transecto do Mar Virado (Tab. 15 e Fig. 10 b), o teste 
estatístico considerou os pontos amostrais significativamente diferentes para clorofila $\underline{a}(p=0,0061)$ e para feopigmentos $(p=0,0002)$.

A comparação múltipla para os pontos amostrais do transecto do Mar Virado formou três grupos distintos para clorofila $\underline{a}$, onde o grupo de maior biomassa foi formado pelo ponto amostral $A$, mas associado com o grupo de biomassa intermediária; o grupo de menor biomassa foi formado pelos pontos amostrais C e F, mas associado com o grupo de biomassa intermediária; e o grupo com biomassa intermediária foi formado pelos pontos amostrais $E, B$ e D e associado com os demais grupos. Para feopigmentos também foram formados três grupos distintos, onde o ponto amostral D formou o grupo de maior biomassa, mas associado com o grupo de biomassa intermediária; o grupo de menor biomassa foi formado pelos pontos amostrais $C, F, B$ e E, mas associado com o grupo de biomassa intermediária; e o grupo de biomassa intermediária foi formado apenas pelo ponto amostral $A$ e associado com os demais grupos (Tab. 15).

Tabela 15: Resultados do Teste de Kruskal-Wallis $(\alpha<0,05)$, com a comparação múltipla (do tipo Tukey) de Nemenyi para o estudo piloto do transecto do Mar Virado.

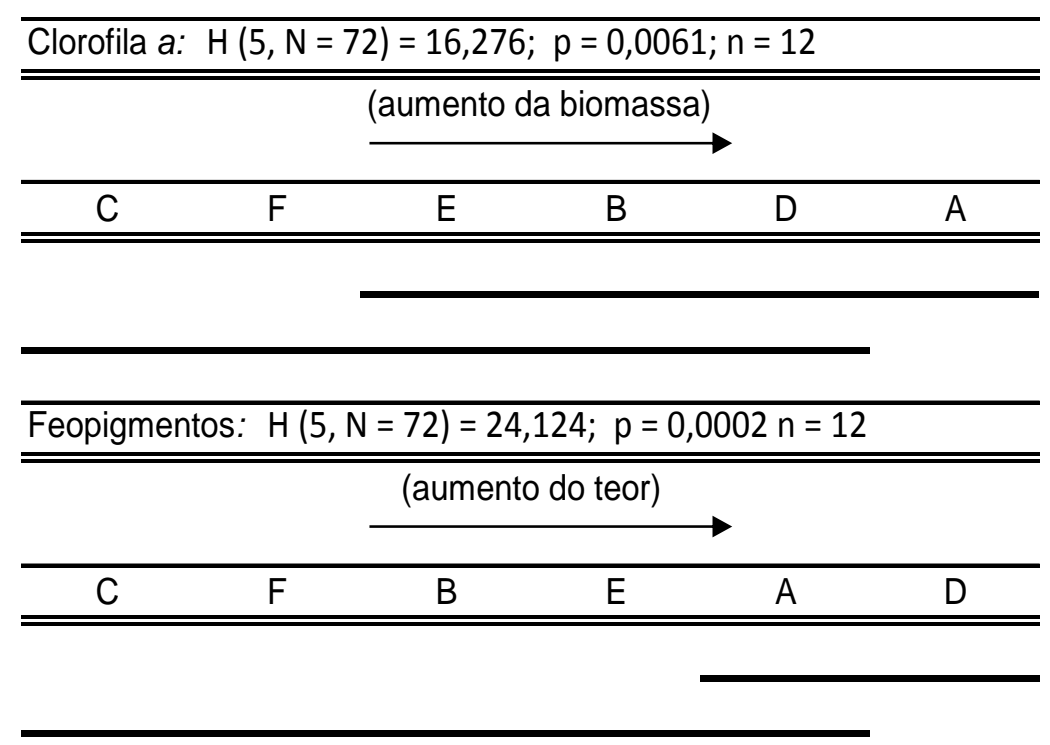

Clorofila $\underline{a}$ se correlacionou positivamente com feopigmentos. Feopigmentos se correlacionaram positivamente com profundidade, carbono 
orgânico total, matéria orgânica e argila, enquanto se correlacionaram negativamente com irradiância no sedimento e silte, conforme a tabela 16.

O índice de Margalef se correlacionou positivamente com profundidade, enquanto se correlacionou negativamente com irradiância no sedimento, carbonato de cálcio, diâmetro médio dos grãos do sedimento e silte, conforme a tabela 16.

A razão $\mathrm{cl}$ a / feo se correlacionou positivamente com irradiância no sedimento e silte, enquanto se correlacionou negativamente com profundidade, carbono orgânico total, matéria orgânica e argila, conforme a tabela 16.

Tabela 16: Correlações $(N=72)$ de Spearman $(r)$, entre as variáveis avaliadas para o estudo piloto do transecto do Mar Virado.

\begin{tabular}{c|c|c}
\hline Variáveis & Spearman & $\mathrm{p}$-nível \\
\hline Clorofila a X Feopigmentos & 0,682 & 0,000000 \\
\hline Feopigmentos X Profundidade & 0,329 & 0,004763 \\
\hline Feopigmentos X Irradiância no sedimento & $-0,329$ & 0,004763 \\
\hline Feopigmentos X Carbono orgânico total & 0,269 & 0,022407 \\
\hline Feopigmentos X Matéria orgânica & 0,290 & 0,013598 \\
\hline Feopigmentos X Silte & $-0,274$ & 0,019895 \\
\hline Feopigmentos X Argila & 0,302 & 0,009907 \\
\hline Margalef X Profundidade & 0,375 & 0,001162 \\
\hline Margalef X Irradiância no sedimento & $-0,375$ & 0,001162 \\
\hline Margalef X Carbonato de cálcio & $-0,356$ & 0,002128 \\
\hline Margalef X Diâmetro médio dos grãos do sedimento & $-0,364$ & 0,001655 \\
\hline Margalef X Silte & $-0,500$ & 0,000008 \\
\hline Cl a / Feo X Profundidade & $-0,582$ & 0,000000 \\
\hline Cl a / Feo X Irradiância no sedimento & 0,582 & 0,000000 \\
\hline Cl a / Feo X Carbono orgânico total & $-0,497$ & 0,000009 \\
\hline Cl a / Feo X Matéria orgânica & $-0,485$ & 0,000016 \\
\hline Cl a / Feo X Silte & 0,265 & 0,024300 \\
\hline Cl a / Feo X Argila & $-0,459$ & 0,000050 \\
\hline
\end{tabular}

\section{2. Amostragem do verão de 2013}

O item "5.2.1." apresenta os resultados da amostragem do verão de 2013 do transecto do Flamengo. O item "5.2.2." apresenta os resultados da amostragem do verão de 2013 do transecto da Fortaleza. O item "5.2.3." apresenta os resultados da amostragem do verão de 2013 do transecto do Mar 
Virado. Por último, o item "5.2.4." apresenta os resultados médios da amostragem do verão de 2013, comparando os transectos entre si.

\section{2. 1. Transecto do Flamengo}

A tabela 17 apresenta os resultados ambientais, tais como profundidade dos pontos de coleta, profundidade de desaparecimento do disco de Secchi, temperatura, salinidade, coeficiente de luz e irradiância no sedimento.

Tabela 17: Valores de profundidade (prof.), profundidade de desaparecimento do disco de Secchi (Secchi), temperatura $\left(\mathrm{T}^{\circ} \mathrm{O}\right)$, salinidade $(\mathrm{S})$, coeficiente de extinção de luz $(\mathrm{K})$ e irradiância no sedimento $\left(\mathrm{I}_{(z)}\right)$ para a amostragem do verão de 2013 do transecto do Flamengo.

\begin{tabular}{c|c|c|c|c|c|c}
\hline $\begin{array}{c}\text { Pontos } \\
\text { amostrais }\end{array}$ & Prof. & Secchi & $\mathrm{T}{ }^{\circ} \mathrm{C}$ & $\mathrm{S}$ & $\mathrm{K}$ & $\mathrm{I}_{(\mathrm{z})}(\%)$ \\
\hline A & 5 & 4,0 & 27,12 & 36 & 0,425 & 11,946 \\
\hline B & 10 & 9,0 & 26,13 & 36 & 0,189 & 15,127 \\
\hline C & 15 & 14,0 & 23,90 & 36 & 0,121 & 16,183 \\
\hline D & 20 & 14,0 & 22,41 & 38 & 0,121 & 8,818 \\
\hline E & 25 & 13,8 & 19,55 & 38 & 0,123 & 4,599 \\
\hline F & 30 & 12,0 & 16,93 & 38 & 0,142 & 1,427 \\
\hline
\end{tabular}

A profundidade de desaparecimento do disco de Secchi variou entre 4,0 e 12,0 metros, a temperatura variou entre 16,93 e $27,12^{\circ} \mathrm{C}$, a salinidade variou entre 36 e 38, o coeficiente de extinção de luz variou entre 0,142 e 0,425 e a irradiância no sedimento variou entre 1,427 e 16,183 (Tab. 17).

A tabela 18 apresenta os teores granulométricos, teores de carbonato de cálcio, de matéria orgânica e de carbono orgânico total, valores de diâmetro médio dos grãos do sedimento e a classificação do sedimento. 
Tabela 18: Teores de grânulos (Gr.), areia (Ar.), silte (Sil.), argila (Arg.), carbonato de cálcio $\left(\mathrm{CaCO}_{3}\right)$, matéria orgânica (M.O.), carbono orgânico total (C.O.T.), valores de diâmetro médio dos grãos do sedimento $(\Phi)$ e a classificação do sedimento proposta por Folk \& Ward (1957) para a amostragem do verão de 2013 do transecto do Flamengo.

\begin{tabular}{c|c|c|c|c|c|c|c|c|c}
\hline $\begin{array}{c}\text { Pontos } \\
\text { amostrais }\end{array}$ & $\begin{array}{c}\text { Gr. } \\
(\%)\end{array}$ & $\begin{array}{c}\text { Ar. } \\
(\%)\end{array}$ & $\begin{array}{c}\text { Sil. } \\
(\%)\end{array}$ & $\begin{array}{c}\text { Arg. } \\
(\%)\end{array}$ & $\begin{array}{c}\mathrm{CaCO}_{3} \\
(\%)\end{array}$ & $\begin{array}{c}\text { M.O. } \\
(\%)\end{array}$ & $\begin{array}{c}\text { C.O.T. } \\
(\%)\end{array}$ & $(\Phi)$ & $\begin{array}{c}\text { Class. } \\
\text { (Folk \& Ward) }\end{array}$ \\
\hline A & 0,56 & 14,73 & 61,18 & 23,53 & 24,40 & 12,04 & 1,98 & 6,34 & silte fino \\
\hline B & 0,26 & 73,39 & 17,57 & 8,78 & 12,40 & 4,00 & 0,71 & 4,67 & silte grosso \\
\hline C & 3,47 & 49,84 & 33,35 & 13,34 & 37,80 & 5,32 & 1,00 & 4,24 & silte grosso \\
\hline D & 4,20 & 38,38 & 35,34 & 22,08 & 20,88 & 6,96 & 1,42 & 4,78 & silte grosso \\
\hline E & 0,84 & 39,72 & 33,03 & 26,42 & 43,86 & 8,40 & 1,89 & 5,53 & silte médio \\
\hline F & 1,50 & 71,40 & 18,76 & 8,34 & 22,60 & 4,36 & 0,81 & 3,36 & areia muito fina \\
\hline
\end{tabular}

Os teores de grânulos variaram entre 0,26 e 4,20\%, de areia variaram entre 14,73 e $73,39 \%$, de silte variaram entre 18,76 e $61,18 \%$, de argila variaram entre 8,34 e $26,42 \%$, de carbonato de cálcio variaram entre 12,40 e 43,86\%, de matéria orgânica variaram entre 4,0 e 12,04\%, de carbono orgânico total variaram entre 0,71 e $1,98 \%$ e os valores de diâmetros médios do sedimento variaram de 3,36 a 6,34 $\Phi$ entre as amostras (Tab. 18).

A tabela 19 apresenta os valores médios, desvios padrão de clorofila $\underline{a}$, feopigmentos, índices de Margalef e razão $\mathrm{cl}$ a / feo para o transecto do Flamengo. A tabela 20 apresenta os resultados do teste estatístico Kruskal Wallis com a comparação múltipla (do tipo Tukey) de Nemenyi. A tabela 21 apresenta os resultados das correlações de Spearman entre as variáveis avaliadas com nível de significância $(\alpha<0,05)$.

Os valores médios dos pigmentos para o transecto da Enseada do Flamengo foram de 18,5 $\pm 11,4 \mathrm{mg} \cdot \mathrm{m}^{-2}$ para clorofila a e de $28,4 \pm 16,2 \mathrm{mg} \cdot \mathrm{m}^{-2}$ para feopigmentos, conforme a tabela 19.

As médias das amostras variaram entre 5,4 (amostra F2) e 42,6 mg.m-2 (amostra A2) para clorofila a e entre 9,2 (amostra F2) e 52,5 mg.m-2 (amostra A2) para feopigmentos. Em quase todas as amostras, os teores de feopigmentos foram superiores aos de clorofila a a a única exceção ocorreu na amostra A1, onde o teor de clorofila a foi maior que de feopigmentos (Tab. $19 \mathrm{e}$ Fig. $14 \mathrm{a}$ ). 
Para o transecto do Flamengo, a média do índice de Margalef foi de 4,2 $\pm 0,8$ e a média da razão de $\mathrm{cl} \underline{\text { a }} /$ feo foi de $0,7 \pm 0,4$. Os índices médios de Margalef variaram entre 3,0 (amostra D1) e 5,2 (amostra F2), enquanto as médias da razão cl a / feo variaram entre 0,5 (amostras D1, E1, E2, E3 e F1) e 1,5 (amostra A1), conforme a tabela 19.

Tabela 19: Valores das médias e dos desvios padrão amostrais para clorofila a $\left(\mathrm{mg} \cdot \mathrm{m}^{-2}\right)$, feopigmentos $\left(\mathrm{mg} \cdot \mathrm{m}^{-2}\right)$, índice de Margalef e razão $\mathrm{cl} \underline{\mathrm{a}} / \mathrm{feo}$ para a amostragem do verão de 2013 do transecto do Flamengo $\left(\mathrm{N}_{\mathrm{amostra}}=4\right.$; $\mathrm{N}_{\text {ponto }}=12 ; \mathrm{N}_{\text {transecto }}=72$ ).

\begin{tabular}{c|c|c|c|c|c|c|c|c}
\hline & \multicolumn{2}{|c|}{ Clorofila a } & \multicolumn{2}{c|}{ Feopigmentos } & \multicolumn{2}{c|}{ Margalef } & \multicolumn{2}{c}{ Cl a / feo } \\
\hline $\begin{array}{c}\text { Amostras } \\
\text { e Pontos }\end{array}$ & Média & Desvio & Média & Desvio & Média & Desvio & Média & Desvio \\
\hline A1 & 33,9 & 3,3 & 30,0 & 13,6 & 3,7 & 0,0 & 1,5 & 0,8 \\
\hline A2 & 42,6 & 14,0 & 52,5 & 18,1 & 3,6 & 0,2 & 0,8 & 0,1 \\
\hline A3 & 39,0 & 7,0 & 39,5 & 13,4 & 3,7 & 0,3 & 1,2 & 0,5 \\
\hline Ponto A & 38,5 & 9,1 & 40,7 & 16,8 & 3,7 & 0,2 & 1,2 & 0,6 \\
\hline B1 & 23,0 & 5,4 & 27,2 & 4,8 & 3,5 & 0,4 & 0,8 & 0,1 \\
\hline B2 & 22,3 & 3,9 & 29,1 & 5,3 & 3,7 & 0,3 & 0,8 & 0,1 \\
\hline B3 & 20,5 & 3,9 & 26,4 & 4,6 & 3,2 & 0,8 & 0,8 & 0,1 \\
\hline Ponto B & 21,9 & 4,2 & 27,6 & 4,6 & 3,5 & 0,5 & 0,8 & 0,1 \\
\hline C1 & 15,8 & 3,5 & 23,0 & 6,2 & 3,9 & 0,4 & 0,7 & 0,1 \\
\hline C2 & 16,7 & 1,2 & 18,8 & 3,9 & 3,9 & 0,5 & 0,9 & 0,1 \\
\hline C3 & 10,7 & 4,4 & 24,9 & 20,8 & 4,2 & 0,6 & 0,6 & 0,3 \\
\hline Ponto C & 14,4 & 4,1 & 22,2 & 11,8 & 4,0 & 0,5 & 0,7 & 0,2 \\
\hline D1 & 22,5 & 9,2 & 46,2 & 15,2 & 3,0 & 1,2 & 0,5 & 0,2 \\
\hline D2 & 14,7 & 4,2 & 30,3 & 18,8 & 4,8 & 0,4 & 0,8 & 0,7 \\
\hline D3 & 14,3 & 2,9 & 38,9 & 29,3 & 4,6 & 0,4 & 0,6 & 0,4 \\
\hline Ponto D & 17,2 & 6,8 & 38,4 & 21,0 & 4,1 & 1,1 & 0,6 & 0,4 \\
\hline E1 & 12,9 & 1,5 & 29,5 & 10,7 & 5,0 & 0,4 & 0,5 & 0,1 \\
\hline E2 & 11,8 & 0,9 & 27,6 & 17,1 & 4,7 & 0,3 & 0,5 & 0,2 \\
\hline E3 & 11,4 & 1,1 & 21,6 & 4,7 & 4,9 & 0,3 & 0,5 & 0,1 \\
\hline Ponto E & 12,0 & 1,3 & 26,3 & 11,4 & 4,9 & 0,3 & 0,5 & 0,1 \\
\hline F1 & 8,1 & 5,1 & 20,6 & 20,6 & 4,7 & 0,6 & 0,5 & 0,1 \\
\hline F2 & 5,4 & 2,3 & 9,2 & 4,1 & 5,2 & 0,4 & 0,6 & 0,1 \\
\hline F3 & 7,8 & 2,7 & 15,3 & 9,6 & 4,6 & 0,4 & 0,6 & 0,2 \\
\hline Ponto F & 7,1 & 3,5 & 15,0 & 13,0 & 4,8 & 0,5 & 0,6 & 0,1 \\
\hline Transecto & 18,5 & 11,4 & 28,4 & 16,2 & 4,2 & 0,8 & 0,7 & 0,4 \\
\hline & & & & & & & &
\end{tabular}




\section{Transecto do Flamengo}

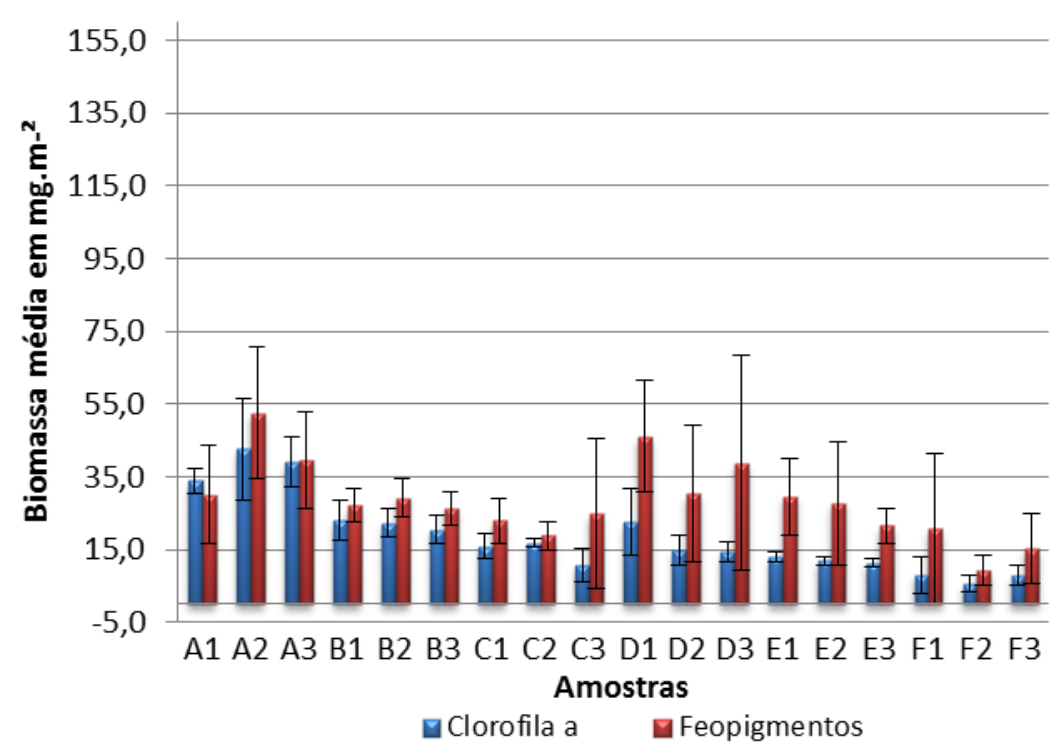

Figura 14 a: Distribuição da biomassa média microfitobentônica por amostras no transecto do Flamengo (verão de 2013).

\section{Transecto do Flamengo}

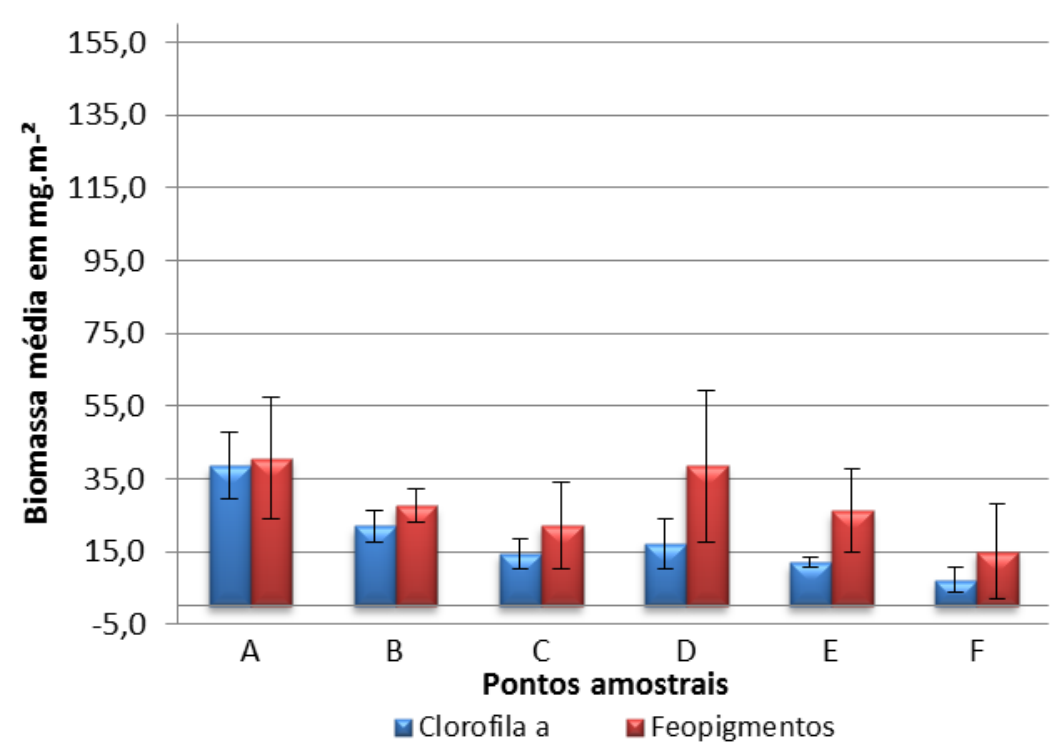

Figura 14 b: Distribuição da biomassa média microfitobentônica por pontos amostrais no transecto do Flamengo (verão de 2013).

Ao comparar a distribuição da biomassa do microfitobentos para a amostragem do verão de 2013 do transecto do Flamengo (Tab. 20 e Fig. 14 b), o teste estatístico considerou os pontos amostrais significativamente diferentes $(\alpha<0,05)$ para clorofila $\underline{a}(p=0,0000)$ e para feopigmentos $(p=0,0002)$. 
A comparação múltipla dos pontos amostrais para o transecto do Flamengo formou três grupos distintos para clorofila a : o grupo de maior biomassa foi formado pelos pontos amostrais $A$ e $B$ e sem associação com os demais grupos; o grupo de biomassa intermediária foi formado apenas pelo ponto amostral $\mathrm{D}$ e sem associação com os demais grupos; o grupo de menor biomassa foi formado pelos pontos amostrais C, E e F. Para feopigmentos também foram formados três grupos distintos: os pontos amostrais $A, B$ e $D$ formaram o grupo de maior teor, mas associado com o ponto amostral E; o ponto amostral $\mathrm{E}$ formou o grupo de teor intermediário, mas associado com os grupos demais grupos; e os pontos amostrais $\mathrm{C}$ e $\mathrm{F}$ formaram o grupo de menor teor, mas associado com o grupo de teor intermediário (Tab. 20).

Tabela 20: Resultados do Teste de Kruskal-Wallis $(\alpha<0,05)$, com a comparação múltipla (do tipo Tukey) de Nemenyi para a amostragem do verão de 2013 do transecto do Flamengo.

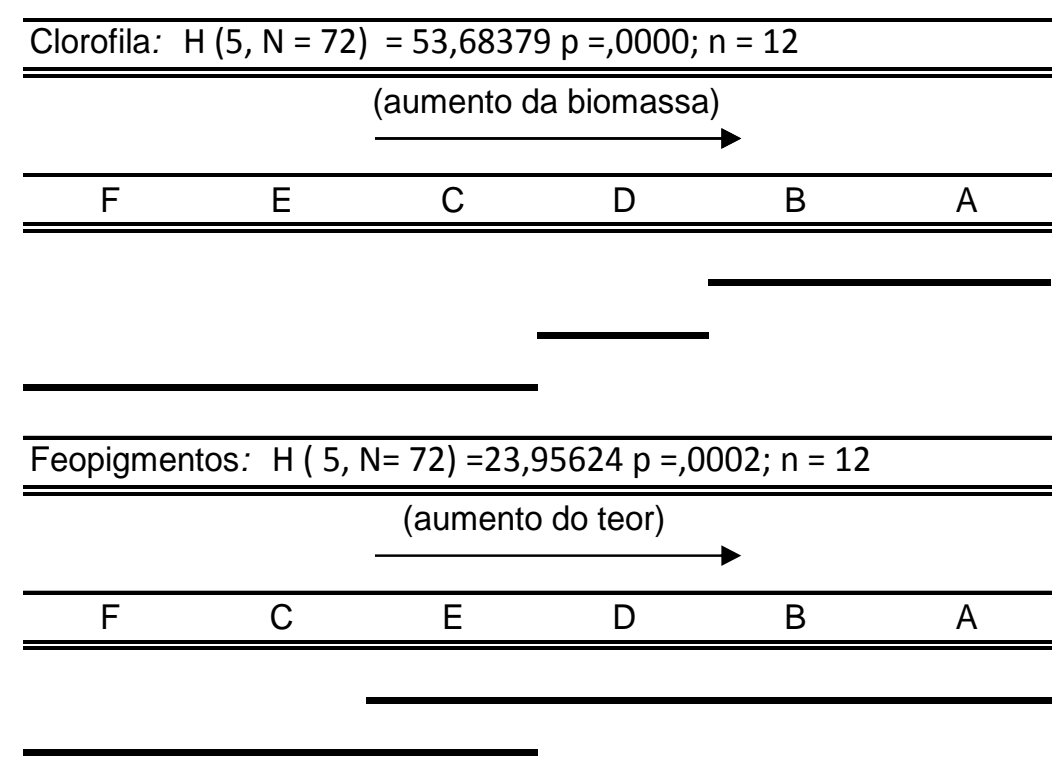

Clorofila $\underline{a}$ se correlacionou positivamente com feopigmentos, irradiância no sedimento, temperatura, carbono orgânico total, matéria orgânica, diâmetro médio dos grãos do sedimento, silte e argila, enquanto se correlacionou negativamente com profundidade, grânulos e areia, sendo a uma forte correlação com a profundidade, conforme a tabela 21 . 
Feopigmentos se correlacionaram positivamente com temperatura, carbono orgânico total, matéria orgânica, diâmetro médio dos grãos do sedimento, silte e argila, enquanto se correlacionaram negativamente com profundidade e areia, conforme a tabela 21.

O índice de Margalef se correlacionou positivamente com profundidade, salinidade, carbonato de cálcio e grânulos, enquanto se correlacionou negativamente com irradiância no sedimento e temperatura, conforme a tabela 21 . A razão $\mathrm{cl}$ a / feo se correlacionou positivamente com irradiância no sedimento e temperatura, enquanto se correlacionou negativamente com profundidade, salinidade e grânulos, conforme a tabela 21.

Tabela 21: Correlações $(N=72)$ de Spearman $(r)$, entre as variáveis avaliadas para a amostragem do verão de 2013 do transecto do Flamengo.

\begin{tabular}{|c|c|c|}
\hline Variáveis & Spearman & p-nível \\
\hline Clorofila a X Feopigmentos & 0,605 & 0,000000 \\
\hline Clorofila a X Profundidade & $-0,833$ & 0,000000 \\
\hline Clorofila a X Irradiância no sedimento & 0,516 & 0,000003 \\
\hline Clorofila a X Salinidade & $-0,616$ & 0,000000 \\
\hline Clorofila a $\times$ Temperatura & 0,833 & 0,000000 \\
\hline Clorofila $\underline{a} \times$ Carbono orgânico total & 0,294 & 0,012105 \\
\hline Clorofila a X Matéria orgânica & 0,294 & 0,012105 \\
\hline Clorofila a X Diâmetro médio dos grãos do sedimento & 0,575 & 0,000000 \\
\hline Clorofila a X Grânulos & $-0,422$ & 0,000224 \\
\hline Clorofila a X Areia & $-0,359$ & 0,001966 \\
\hline Clorofila a X Silte & 0,396 & 0,000582 \\
\hline Clorofila a X Argila & 0,292 & 0,012717 \\
\hline Feopigmentos $\bar{X}$ Profundidade & $-0,433$ & 0,000144 \\
\hline Feopigmentos X Temperatura & 0,433 & 0,000144 \\
\hline Feopigmentos X Carbono orgânico total & 0,298 & 0,010958 \\
\hline Feopigmentos X Matéria orgânica & 0,298 & 0,010958 \\
\hline Feopigmentos X Diâmetro médio dos grãos do sedimento & 0,485 & 0,000016 \\
\hline Feopigmentos X Areia & $-0,352$ & 0,002443 \\
\hline Feopigmentos X Silte & 0,320 & 0,006058 \\
\hline Feopigmentos X Argila & 0,342 & 0,003240 \\
\hline Margalef X Profundidade & 0,712 & 0,000000 \\
\hline Margalef X Irradiância no sedimento & $-0,614$ & 0,000000 \\
\hline Margalef X Salinidade & 0,667 & 0,000000 \\
\hline Margalef X Temperatura & $-0,712$ & 0,000000 \\
\hline Margalef $\mathrm{X} \mathrm{CaCO}_{3}$ & 0,313 & 0,007416 \\
\hline Margalef X Grânulos & 0,322 & 0,005801 \\
\hline $\mathrm{Cl} \underline{\mathrm{a}}$ / Feo X Profundidade & $-0,673$ & 0,000000 \\
\hline $\mathrm{Cl}$ a / Feo X Irradiância no sedimento & 0,517 & 0,000003 \\
\hline $\mathrm{Cl} \underline{\mathrm{a}}$ / Feo X Salinidade & $-0,667$ & 0,000000 \\
\hline $\mathrm{Cl} \underline{\mathrm{a}}$ / Feo X Temperatura & 0,673 & 0,000000 \\
\hline Cl a / Feo X Grânulos & $-0,385$ & 0,000838 \\
\hline
\end{tabular}




\section{2. Transecto da Fortaleza}

A tabela 22 apresenta os resultados ambientais, tais como profundidade dos pontos de coleta, profundidade de desaparecimento do disco de Secchi, temperatura, salinidade, coeficiente de luz e irradiância no sedimento.

Tabela 22: Valores de profundidade (prof.), profundidade de desaparecimento do disco de Secchi (Secchi), temperatura $\left(\mathrm{T}^{\circ} \mathrm{O}\right)$, salinidade (S), coeficiente de extinção de luz $(K)$ e irradiância no sedimento $\left(I_{(z)}\right)$ para a amostragem do verão de 2013 do transecto da Fortaleza.

\begin{tabular}{c|c|c|c|c|c|c}
\hline $\begin{array}{c}\text { Pontos } \\
\text { amostrais }\end{array}$ & Prof. & Secchi & $\mathrm{T} \stackrel{\circ}{ } \mathrm{C}$ & $\mathrm{S}$ & $\mathrm{K}$ & $\mathrm{I}_{(\mathrm{z})}(\%)$ \\
\hline A & 5 & 4,5 & 26,83 & 36 & 0,378 & 15,127 \\
\hline $\mathrm{B}$ & 10 & 9,5 & 24,94 & 37 & 0,179 & 16,708 \\
\hline C & 15 & 14,5 & 25,43 & 36 & 0,117 & 17,231 \\
\hline $\mathrm{D}$ & 20 & 15,5 & 21,98 & 37 & 0,110 & 11,155 \\
\hline $\mathrm{E}$ & 25 & 11,0 & 16,81 & 36 & 0,155 & 2,100 \\
\hline F & 30 & 12,0 & 16,73 & 37 & 0,142 & 1,427 \\
\hline
\end{tabular}

A profundidade de desaparecimento do disco de Secchi variou entre 4,5 e 15,5 metros, a temperatura variou entre 16,73 e $26,83^{\circ} \mathrm{C}$, a salinidade variou entre 36 e 37, o coeficiente de extinção de luz variou entre 0,142 e 0,378 e a irradiância no sedimento variou entre 1,427 e 17,231\% (Tab. 22).

A tabela 23 apresenta os teores granulométricos, teores de carbonato de cálcio, de matéria orgânica e de carbono orgânico total, valores de diâmetro médio dos grãos do sedimento e a classificação do sedimento.

Os teores de grânulos variaram entre 0,0 e $13,43 \%$, de areia variaram entre 22,72 e $91,40 \%$, de silte variaram entre 3,67 e $70,95 \%$, de argila variaram entre 0,0 e 13,54\%, de carbonato de cálcio variaram entre 14,99 e $39,72 \%$, de matéria orgânica variaram entre 1,48 e $7,12 \%$, de carbono orgânico total variaram entre 0,13 e 1,19\% e os valores de diâmetros médios do sedimento variaram de 0,97 a 4,95 $\Phi$ entre as amostras (Tab. 23). 
Tabela 23: Teores de grânulos (Gr.), areia (Ar.), silte (Sil.), argila (Arg.), carbonato de cálcio $\left(\mathrm{CaCO}_{3}\right)$, matéria orgânica (M.O.), carbono orgânico total (C.O.T.), valores de diâmetro médio dos grãos do sedimento $(\Phi)$ e a classificação do sedimento proposta por Shepard (1954) e Folk \& Ward (1957) para a amostragem do verão de 2013 do transecto da Fortaleza.

\begin{tabular}{c|c|c|c|c|c|c|c|c|c}
\hline $\begin{array}{c}\text { Pontos } \\
\text { amostrais }\end{array}$ & $\begin{array}{c}\text { Gr. } \\
(\%)\end{array}$ & $\begin{array}{c}\text { Ar. } \\
(\%)\end{array}$ & $\begin{array}{c}\text { Sil. } \\
(\%)\end{array}$ & $\begin{array}{c}\text { Arg. } \\
(\%)\end{array}$ & $\begin{array}{c}\mathrm{CaCO}_{3} \\
(\%)\end{array}$ & $\begin{array}{c}\text { M.O. } \\
(\%)\end{array}$ & $\begin{array}{c}\text { C.O.T. } \\
(\%)\end{array}$ & $(\Phi)$ & $\begin{array}{c}\text { Class. } \\
(\text { Folk \& Ward) }\end{array}$ \\
\hline A & 13,43 & 24,13 & 49,06 & 13,38 & 39,72 & 6,24 & 1,19 & 3,94 & areia muito fina \\
\hline B & 0,05 & 52,23 & 34,18 & 13,54 & 17,58 & 7,12 & 1,13 & 4,95 & silte grosso \\
\hline C & 0,00 & 22,72 & 70,95 & 6,33 & 14,99 & 2,44 & 0,34 & 4,51 & silte grosso \\
\hline D & 0,39 & 42,99 & 43,55 & 13,07 & 19,38 & 5,08 & 0,98 & 4,95 & silte grosso \\
\hline E & 0,67 & 76,43 & 14,58 & 8,33 & 16,28 & 3,92 & 0,45 & 3,56 & areia muito fina \\
\hline F & 4,93 & 91,40 & 3,67 & 0,00 & 24,18 & 1,48 & 0,13 & 0,97 & areia grossa \\
\hline
\end{tabular}

A tabela 24 apresenta os valores médios, desvios padrão de clorofila a feopigmentos, índices de Margalef e razão $\mathrm{cl}$ a / feo para o transecto da Fortaleza. A tabela 25 apresenta os resultados do teste estatístico Kruskal Wallis e a comparação múltipla (do tipo Tukey) de Nemenyi. A Tabela 26 apresenta os resultados das correlações de Spearman entre as variáveis avaliadas com nível de significância $(\alpha<0,05)$.

Os valores médios dos pigmentos para o transecto da Fortaleza foram de $11,5 \pm 11,3 \mathrm{mg} \cdot \mathrm{m}^{-2}$ para clorofila $\underline{\text { a }}$ e de $13,7 \pm 13,6 \mathrm{mg} \cdot \mathrm{m}^{-2}$ para feopigmentos, conforme a tabela 24 e a figura 12.

As médias das amostras variaram entre 3,3 (amostra F2) e 37,4 mg.m-2 (amostra A3) para clorofila a e entre 1,8 (amostra F3) e 45,6 mg.m-2 (amostra A3) para feopigmentos (Tab. 24 e Fig. 12 a).

Para o transecto da Fortaleza, a média do índice de Margalef foi de 4,1 $\pm 0,9$ e a média da razão $\mathrm{cl} \underline{a} /$ feo foi de $1,1 \pm 0,8$. Os índices médios de Margalef variaram entre 3,1 (amostra F3) e 6,3 (amostra E3), enquanto as médias da razão $\mathrm{Cl}$ a / feo variaram entre 0,7 (amostras B1, B2, B3 e F1) e 2,4 (amostra F3), conforme a tabela 24.

Observando a tabela 24 e a figura 12 b, é possível notar uma grande diferença $\left(34,7 \mathrm{mg}^{-\mathrm{m}^{2}}\right)$ de clorofila a do ponto amostral A (5 metros de profundidade) em relação aos demais pontos amostrais. Mas entre os demais pontos amostrais (B, C, D, E e F), ocorreu um valor médio entre 6,0 e 8,6 $\mathrm{mg} \cdot \mathrm{m}^{-2}$ para clorofila a. Para feopigmentos, os valores variaram um pouco mais 
entre os pontos amostrais, sendo $39,1 \mathrm{mg} \cdot \mathrm{m}^{-2}$ para o ponto amostral $\mathrm{A}$, com uma variação menor entre os pontos amostrais B, C, D, E e F (entre 5,2 e 12,1 $\left.\mathrm{mg} \cdot \mathrm{m}^{2}{ }^{2}\right)$.

Tabela 24: Valores das médias e dos desvios padrão amostrais para clorofila a $\left(\mathrm{mg} \cdot \mathrm{m}^{-2}\right)$, feopigmentos $\left(\mathrm{mg} \cdot \mathrm{m}^{-2}\right)$, índice de Margalef e razão $\mathrm{cl} \underline{\mathrm{a}} / \mathrm{feo}$ para a amostragem do verão de 2013 do transecto da Fortaleza $\left(\mathrm{N}_{\text {amostra }}=4\right.$; $\mathrm{N}_{\text {ponto }}=12 ; \mathrm{N}_{\text {transecto }}=72$ ).

\begin{tabular}{c|c|c|c|c|c|c|c|c}
\hline & \multicolumn{2}{|c|}{ Clorofila $\underline{\underline{a}}$} & \multicolumn{2}{c|}{ Feopigmentos } & \multicolumn{2}{c|}{ Margalef } & \multicolumn{2}{c}{ Cl $\underline{\text { a } / \text { feo }}$} \\
\hline $\begin{array}{c}\text { Amostras } \\
\text { e Pontos }\end{array}$ & Média & Desvio & Média & Desvio & Média & Desvio & Média & Desvio \\
\hline A1 & 32,0 & 6,4 & 31,2 & 3,2 & 3,6 & 0,5 & 1,0 & 0,3 \\
\hline A2 & 34,6 & 5,8 & 40,5 & 11,1 & 4,1 & 0,2 & 0,9 & 0,2 \\
\hline A3 & 37,4 & 11,7 & 45,6 & 22,3 & 3,7 & 0,2 & 0,9 & 0,2 \\
\hline Ponto A & 34,7 & 7,9 & 39,1 & 14,5 & 3,8 & 0,4 & 0,9 & 0,2 \\
\hline B1 & 8,8 & 0,4 & 12,3 & 2,1 & 4,6 & 0,1 & 0,7 & 0,1 \\
\hline B2 & 8,9 & 1,0 & 12,4 & 2,6 & 4,6 & 0,2 & 0,7 & 0,1 \\
\hline B3 & 8,2 & 0,9 & 11,5 & 2,4 & 4,6 & 0,2 & 0,7 & 0,1 \\
\hline Ponto B & 8,6 & 0,8 & 12,1 & 2,2 & 4,6 & 0,1 & 0,7 & 0,1 \\
\hline C1 & 6,7 & 1,1 & 8,9 & 6,0 & 3,5 & 0,1 & 0,9 & 0,4 \\
\hline C2 & 7,6 & 1,7 & 9,8 & 7,1 & 3,6 & 0,2 & 1,0 & 0,5 \\
\hline C3 & 8,0 & 1,8 & 10,2 & 7,0 & 3,6 & 0,3 & 1,0 & 0,4 \\
\hline Ponto C & 7,4 & 1,5 & 9,6 & 6,1 & 3,6 & 0,2 & 1,0 & 0,4 \\
\hline D1 & 9,2 & 10,0 & 7,1 & 2,9 & 4,5 & 0,3 & 1,9 & 2,7 \\
\hline D2 & 6,5 & 1,5 & 7,4 & 1,7 & 4,1 & 0,4 & 0,9 & 0,1 \\
\hline D3 & 6,2 & 1,5 & 6,6 & 2,5 & 3,9 & 0,3 & 1,1 & 0,6 \\
\hline Ponto D & 7,3 & 5,5 & 7,0 & 2,2 & 4,2 & 0,4 & 1,3 & 1,5 \\
\hline E1 & 7,6 & 0,7 & 10,4 & 3,1 & 4,2 & 0,5 & 0,8 & 0,2 \\
\hline E2 & 8,5 & 3,2 & 12,0 & 8,0 & 4,6 & 0,9 & 1,0 & 0,5 \\
\hline E3 & 4,1 & 1,5 & 4,1 & 1,6 & 6,3 & 2,1 & 1,0 & 0,3 \\
\hline Ponto E & 6,7 & 2,7 & 8,9 & 5,8 & 5,0 & 1,6 & 0,9 & 0,4 \\
\hline F1 & 6,8 & 1,4 & 10,4 & 5,5 & 3,6 & 0,1 & 0,7 & 0,2 \\
\hline F2 & 3,3 & 1,7 & 3,9 & 4,2 & 3,5 & 0,1 & 1,5 & 1,2 \\
\hline F3 & 3,5 & 0,9 & 1,8 & 1,0 & 3,1 & 0,7 & 2,4 & 1,2 \\
\hline Ponto F & 4,5 & 2,0 & 5,3 & 5,3 & 3,4 & 0,4 & 1,5 & 1,1 \\
\hline Transecto & 11,5 & 11,3 & 13,7 & 13,6 & 4,1 & 0,9 & 1,1 & 0,8 \\
\hline & & & & & & & &
\end{tabular}




\section{Transecto da Fortaleza}

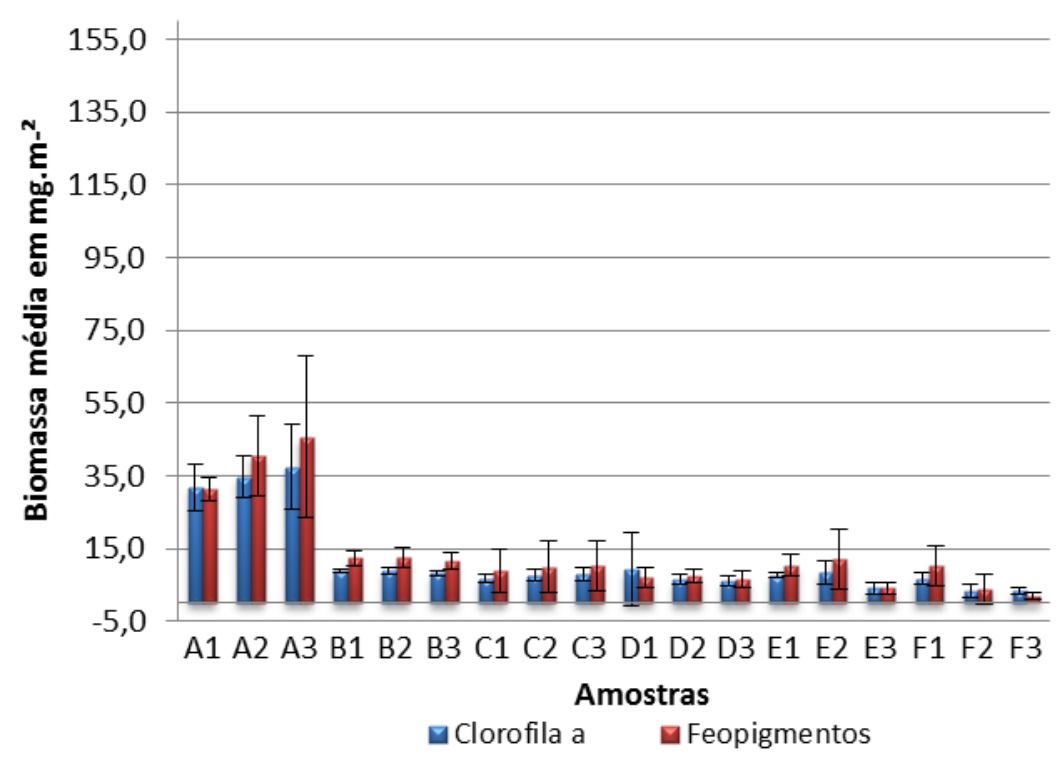

Figura 12 a: Distribuição da biomassa média microfitobentônica por amostras no transecto da Fortaleza (verão de 2013).

\section{Transecto da Fortaleza}

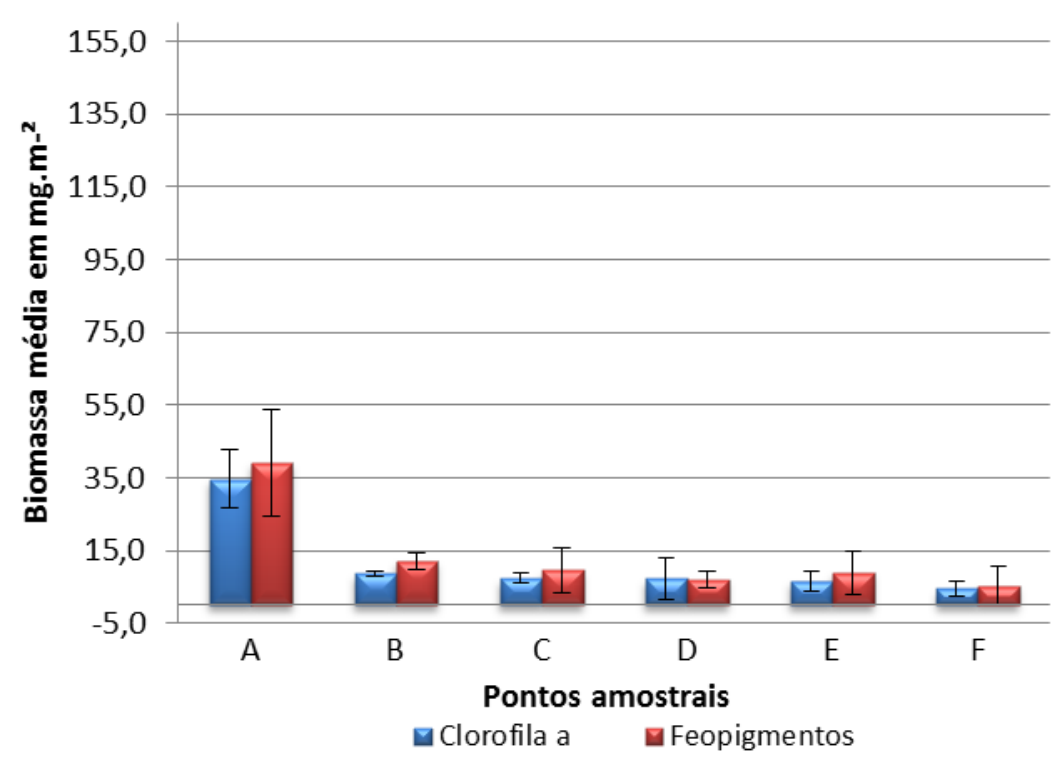

Figura 12 b: Distribuição da biomassa média microfitobentônica por pontos amostrais no transecto da Fortaleza (verão de 2013).

Ao comparar a distribuição da biomassa do microfitobentos para a amostragem do verão de 2013 do transecto da Fortaleza (Tab. 25 e Fig. 12 b), 
o teste estatístico considerou os pontos amostrais significativamente diferentes para clorofila $\underline{a}(p=0,0000)$ e para feopigmentos $(p=0,0000)$.

A comparação múltipla para os pontos amostrais do transecto da Fortaleza formou dois grupos distintos para clorofila a: onde o grupo de maior biomassa foi formado pelos pontos amostrais A e B e sem associação com 0 grupo de menor biomassa; os pontos amostrais C, D, E e F formaram o grupo de menor biomassa. Para feopigmentos também foram formados dois grupos distintos: o grupo de maior teor também foi formado pelos pontos amostrais $A$ e B e sem associação com o grupo de menor teor; enquanto o grupo de menor teor foi formado pelos pontos amostrais C, E, D e F (Tab. 25).

Tabela 25: Resultados do Teste de Kruskal-Wallis $(\alpha<0,05)$, com a comparação múltipla (do tipo Tukey) de Nemenyi para a amostragem do verão de 2013 do transecto da Fortaleza.

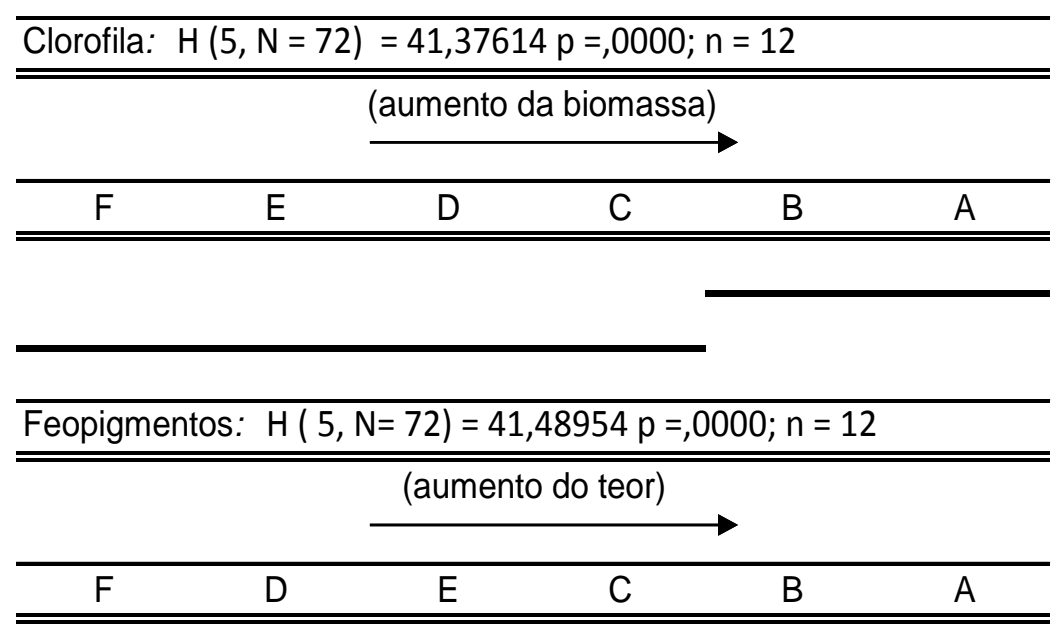

Clorofila $\underline{a}$ se correlacionou positivamente com feopigmentos, irradiância no sedimento, temperatura, carbonato de cálcio, carbono orgânico total, matéria orgânica, silte e argila, enquanto se correlacionou negativamente com profundidade, salinidade, areia, conforme a Tabela 26.

Feopigmentos se correlacionaram positivamente com irradiância no sedimento, temperatura, carbonato de cálcio, carbono orgânico total, matéria 
orgânica, silte e argila, enquanto se correlacionaram negativamente com profundidade, salinidade e areia, conforme a tabela 26.

O índice de Margalef se correlacionou positivamente com carbono orgânico total, matéria orgânica, diâmetro médio dos grãos do sedimento e argila, conforme a tabela 26.

A razão $\mathrm{cl}$ a / feo se correlacionou negativamente com matéria orgânica, diâmetro médio dos grãos do sedimento e argila, conforme a tabela 26.

Tabela 26: Correlações $(N=72)$ de Spearman $(r)$, entre as variáveis avaliadas para a amostragem do verão de 2013 do transecto da Fortaleza.

\begin{tabular}{|c|c|c|}
\hline Variáveis & Spearman & p-nível \\
\hline Clorofila $\underline{a} \times$ Feopigmentos & 0,828 & 0,000000 \\
\hline Clorofila a X Profundidade & $-0,699$ & 0,000000 \\
\hline Clorofila a X Irradiância no sedimento & 0,388 & 0,000748 \\
\hline Clorofila a X Salinidade & $-0,327$ & 0,005082 \\
\hline Clorofila a X Temperatura & 0,640 & 0,000000 \\
\hline Clorofila $\underline{a} \times \mathrm{CaCO}_{3}$ & 0,254 & 0,031311 \\
\hline Clorofila a X Carbono orgânico total & 0,643 & 0,000000 \\
\hline Clorofila a X Matéria orgânica & 0,546 & 0,000001 \\
\hline Clorofila a X Areia & $-0,385$ & 0,000833 \\
\hline Clorofila a X Silte & 0,385 & 0,000833 \\
\hline Clorofila a X Argila & 0,546 & 0,000001 \\
\hline Feopigmentos X Profundidade & $-0,696$ & 0,000000 \\
\hline Feopigmentos X Irradiância no sedimento & 0,369 & 0,001433 \\
\hline Feopigmentos X Salinidade & $-0,308$ & 0,008468 \\
\hline Feopigmentos X Temperatura & 0,627 & 0,000000 \\
\hline Feopigmentos $\mathrm{X} \mathrm{CaCO}_{3}$ & 0,268 & 0,022733 \\
\hline Feopigmentos X Carbono orgânico total & 0,664 & 0,000000 \\
\hline Feopigmentos X Matéria orgânica & 0,570 & 0,000000 \\
\hline Feopigmentos X Areia & $-0,367$ & 0,001507 \\
\hline Feopigmentos X Silte & 0,367 & 0,001507 \\
\hline Feopigmentos X Argila & 0,570 & 0,000000 \\
\hline Margalef X Carbono orgânico total & 0,425 & 0,000195 \\
\hline Margalef X Matéria orgânica & 0,564 & 0,000000 \\
\hline Margalef X Diâmetro médio dos grãos do sedimento & 0,377 & 0,001097 \\
\hline Margalef X Argila & 0,564 & 0,000000 \\
\hline $\mathrm{Cl}$ a / Feo X Matéria orgânica & $-0,245$ & 0,038402 \\
\hline $\mathrm{Cl}$ a / Feo X Diâmetro médio dos grãos do sedimento & $-0,244$ & 0,038893 \\
\hline $\mathrm{Cl} \underline{\mathrm{a}} / \mathrm{Feo} \mathrm{X}$ Argila & $-0,245$ & 0,038402 \\
\hline
\end{tabular}




\section{3. Transecto do Mar Virado}

A tabela 27 apresenta os resultados ambientais, tais como profundidade dos pontos de coleta, profundidade de desaparecimento do disco de Secchi, temperatura, salinidade, coeficiente de luz e irradiância no sedimento.

Tabela 27: Valores de profundidade (prof.), profundidade de desaparecimento do disco de Secchi (Secchi), temperatura $\left(\mathrm{T}^{\circ} \mathrm{O} \mathrm{C}\right)$, salinidade (S), coeficiente de extinção de luz $(K)$ e irradiância no sedimento $\left(I_{(z)}\right)$ para a amostragem do verão de 2013 do transecto do Mar Virado.

\begin{tabular}{c|c|c|c|c|c|c}
\hline $\begin{array}{c}\text { Pontos } \\
\text { amostrais }\end{array}$ & Prof. & Secchi & $\mathrm{T} \stackrel{\circ}{ } \mathrm{C}$ & $\mathrm{S}$ & $\mathrm{K}$ & $\mathrm{I}_{(\mathrm{z})}(\%)$ \\
\hline A & 5 & 4,5 & 26,93 & 35 & 0,378 & 15,127 \\
\hline $\mathrm{B}$ & 10 & 9,5 & 23,16 & 37 & 0,179 & 16,708 \\
\hline $\mathrm{C}$ & 15 & 11,0 & 19,05 & 37 & 0,155 & 9,848 \\
\hline $\mathrm{D}$ & 20 & 11,5 & 17,14 & 37 & 0,148 & 5,202 \\
\hline $\mathrm{E}$ & 25 & 12,7 & 16,90 & 38 & 0,134 & 3,522 \\
\hline $\mathrm{F}$ & 30 & 12,5 & 16,84 & 37 & 0,136 & 1,691 \\
\hline
\end{tabular}

A profundidade de desaparecimento do disco de Secchi variou entre 4,5 e 12,7 metros, a temperatura variou entre 16,84 e $26,93^{\circ} \mathrm{C}$, a salinidade variou entre 35 e 38, o coeficiente de extinção de luz variou entre 0,134 e 0,378 e a irradiância no sedimento variou entre 1,691 e 16,708\% (Tab. 27).

A tabela 28 apresenta os teores granulométricos, teores de carbonato de cálcio, de matéria orgânica e de carbono orgânico total, valores de diâmetro médio dos grãos do sedimento e a classificação do sedimento. 
Tabela 28: Teores de grânulos (Gr.), areia (Ar.), silte (Sil.), argila (Arg.), carbonato de cálcio $\left(\mathrm{CaCO}_{3}\right)$, matéria orgânica (M.O.), carbono orgânico total (C.O.T.), valores de diâmetro médio dos grãos do sedimento $(\Phi)$ e a classificação do sedimento proposta por Folk \& Ward (1957) para amostragem do verão de 2013 do transecto do Mar Virado.

\begin{tabular}{c|c|c|c|c|c|c|c|c|c}
\hline $\begin{array}{c}\text { Pontos } \\
\text { amostrais }\end{array}$ & $\begin{array}{c}\text { Gr. } \\
(\%)\end{array}$ & $\begin{array}{c}\text { Ar. } \\
(\%)\end{array}$ & $\begin{array}{c}\text { Sil. } \\
(\%)\end{array}$ & $\begin{array}{c}\text { Arg. } \\
(\%)\end{array}$ & $\begin{array}{c}\mathrm{CaCO}_{3} \\
(\%)\end{array}$ & $\begin{array}{c}\text { M.O. } \\
(\%)\end{array}$ & $\begin{array}{c}\text { C.O.T. } \\
(\%)\end{array}$ & $(\Phi)$ & $\begin{array}{c}\text { Class. } \\
(\text { Folk \& Ward) }\end{array}$ \\
\hline A & 1,71 & 72,65 & 23,50 & 2,14 & 18,38 & 3,16 & 0,37 & 3,63 & areia muito fina \\
\hline B & 0,00 & 12,43 & 81,03 & 6,54 & 21,18 & 3,80 & 0,50 & 4,72 & silte grosso \\
\hline C & 0,00 & 16,84 & 72,18 & 10,99 & 21,70 & 4,16 & 0,67 & 4,86 & silte grosso \\
\hline D & 0,00 & 19,81 & 62,66 & 17,53 & 21,48 & 7,32 & 1,14 & 5,81 & silte médio \\
\hline E & 0,41 & 93,46 & 2,04 & 4,09 & 9,18 & 2,32 & 0,22 & 3,14 & areia muito fina \\
\hline F & 0,74 & 60,23 & 13,01 & 26,02 & 17,76 & 6,39 & 1,06 & 5,03 & silte médio \\
\hline
\end{tabular}

Os teores de grânulos variaram entre 0,0 e 1,71\%, de areia variaram entre 12,43 e $93,46 \%$, de silte variaram entre 2,04 e $81,03 \%$, de argila variaram entre 2,14 e 26,02\%, de carbonato de cálcio variaram entre 9,18 e 21,70\%, de matéria orgânica variaram entre 2,32 e $7,32 \%$, de carbono orgânico total variaram entre 0,22 e 1,14\% e os valores de diâmetros médios do sedimento variaram de 3,14 a 5,81 Ф entre as amostras (Tab. 28).

A tabela 29 apresenta os valores médios, desvios padrão de clorofila a feopigmentos, índices de Margalef e razão cl a / feo para o transecto do Mar Virado. A tabela 30 apresenta os resultados do teste estatístico Kruskal - Wallis com a comparação múltipla (do tipo Tukey) de Nemenyi. A tabela 31 apresenta os resultados das correlações de Spearman entre as variáveis avaliadas com nível de significância $(\alpha<0,05)$.

Os valores médios dos pigmentos para o transecto do Mar Virado foram de 11,9 $\pm 10,2 \mathrm{mg} \cdot \mathrm{m}^{-2}$ para clorofila a e de 18,8 $\pm 15,2 \mathrm{mg} \cdot \mathrm{m}^{-2}$ para feopigmentos, conforme a tabela 29.

As médias das amostras variaram entre 3,8 (amostra E2) e 38,3 mg.m-2 (amostra A2) para clorofila a e 3,5 (amostra B2) e 42,1 mg.m-2 (amostra D3) para feopigmentos (Tab. 29 e Fig. 13 a). 
Tabela 29: Valores das médias e dos desvios padrão amostrais para clorofila a $\left(\mathrm{mg} \cdot \mathrm{m}^{-2}\right)$, feopigmentos (mg. $\left.\mathrm{m}^{-2}\right)$, índice de Margalef e razão $\mathrm{cl} \underline{\text { a }}$ / feo para a amostragem do verão de 2013 do transecto do Mar Virado $\left(N_{\text {amostra }}=4\right.$; $\mathrm{N}_{\text {ponto }}=12 ; \mathrm{N}_{\text {transecto }}=72$ ).

\begin{tabular}{c|c|c|c|c|c|c|c|c}
\hline & \multicolumn{2}{|c|}{ Clorofila $\underline{\underline{a}}$} & \multicolumn{2}{c|}{ Feopigmentos } & \multicolumn{2}{c|}{ Margalef } & \multicolumn{2}{c}{ Cl a / feo } \\
\hline $\begin{array}{c}\text { Amostras } \\
\text { e Pontos }\end{array}$ & Média & Desvio & Média & Desvio & Média & Desvio & Média & Desvio \\
\hline A1 & 31,3 & 8,4 & 25,6 & 8,7 & 3,6 & 0,2 & 1,2 & 0,2 \\
\hline A2 & 38,3 & 11,5 & 40,6 & 18,5 & 3,7 & 0,2 & 1,0 & 0,1 \\
\hline A3 & 20,1 & 4,0 & 14,5 & 3,7 & 3,9 & 0,2 & 1,4 & 0,3 \\
\hline Ponto A & 29,9 & 11,0 & 26,9 & 15,6 & 3,7 & 0,2 & 1,2 & 0,3 \\
\hline B1 & 7,6 & 5,7 & 8,3 & 9,1 & 3,9 & 0,4 & 1,4 & 0,8 \\
\hline B2 & 5,4 & 1,3 & 3,5 & 2,2 & 4,2 & 0,4 & 1,8 & 0,5 \\
\hline B3 & 6,5 & 2,6 & 5,2 & 5,6 & 4,3 & 0,8 & 2,6 & 1,9 \\
\hline Ponto B & 6,5 & 3,5 & 5,7 & 6,1 & 4,2 & 0,5 & 1,9 & 1,2 \\
\hline C1 & 9,0 & 2,7 & 28,4 & 15,5 & 3,9 & 0,4 & 0,4 & 0,1 \\
\hline C2 & 7,7 & 0,6 & 18,6 & 9,5 & 4,5 & 0,7 & 0,5 & 0,3 \\
\hline C3 & 9,6 & 2,1 & 33,8 & 13,1 & 3,7 & 0,3 & 0,3 & 0,1 \\
\hline Ponto C & 8,8 & 2,0 & 26,9 & 13,4 & 4,0 & 0,6 & 0,4 & 0,2 \\
\hline D1 & 8,8 & 2,0 & 7,2 & 1,3 & 4,1 & 0,1 & 1,3 & 0,4 \\
\hline D2 & 17,4 & 2,2 & 35,9 & 9,6 & 4,2 & 0,1 & 0,5 & 0,1 \\
\hline D3 & 19,0 & 3,8 & 42,1 & 15,8 & 4,2 & 0,1 & 0,5 & 0,1 \\
\hline Ponto D & 15,0 & 5,3 & 28,4 & 18,6 & 4,1 & 0,1 & 0,7 & 0,4 \\
\hline E1 & 6,2 & 1,1 & 10,7 & 2,9 & 3,4 & 0,2 & 0,6 & 0,2 \\
\hline E2 & 3,8 & 1,0 & 4,4 & 3,1 & 6,2 & 0,8 & 1,1 & 0,4 \\
\hline E3 & 5,0 & 2,8 & 4,5 & 3,3 & 5,4 & 0,6 & 1,3 & 0,6 \\
\hline Ponto E & 5,0 & 1,9 & 6,5 & 4,1 & 5,0 & 1,3 & 1,0 & 0,5 \\
\hline F1 & 4,8 & 2,5 & 14,9 & 9,4 & 4,9 & 0,6 & 0,3 & 0,1 \\
\hline F2 & 7,3 & 0,9 & 17,4 & 9,9 & 4,1 & 0,4 & 0,5 & 0,2 \\
\hline F3 & 7,2 & 2,2 & 23,2 & 7,7 & 4,4 & 0,6 & 0,3 & 0,0 \\
\hline Ponto F & 6,4 & 2,2 & 18,5 & 8,9 & 4,5 & 0,6 & 0,4 & 0,1 \\
\hline Transecto & 11,9 & 10,2 & 18,8 & 15,2 & 4,3 & 0,8 & 0,9 & 0,8 \\
\hline & & & & & & & &
\end{tabular}

Para o transecto do Mar Virado, a média do índice de Margalef foi de $4,3 \pm 0,8$ e a média da razão de $\mathrm{cl} \underline{\text { a }}$ / feo foi de $0,9 \pm 0,8$. Os índices médios de Margalef variaram entre 3,4 (amostra E1) e 6,2 (amostra E2), enquanto as médias da razão cl a / feo variaram entre 0,4 (amostras C3 e F3) e 2,6 (amostra B3), conforme a tabela 29. 


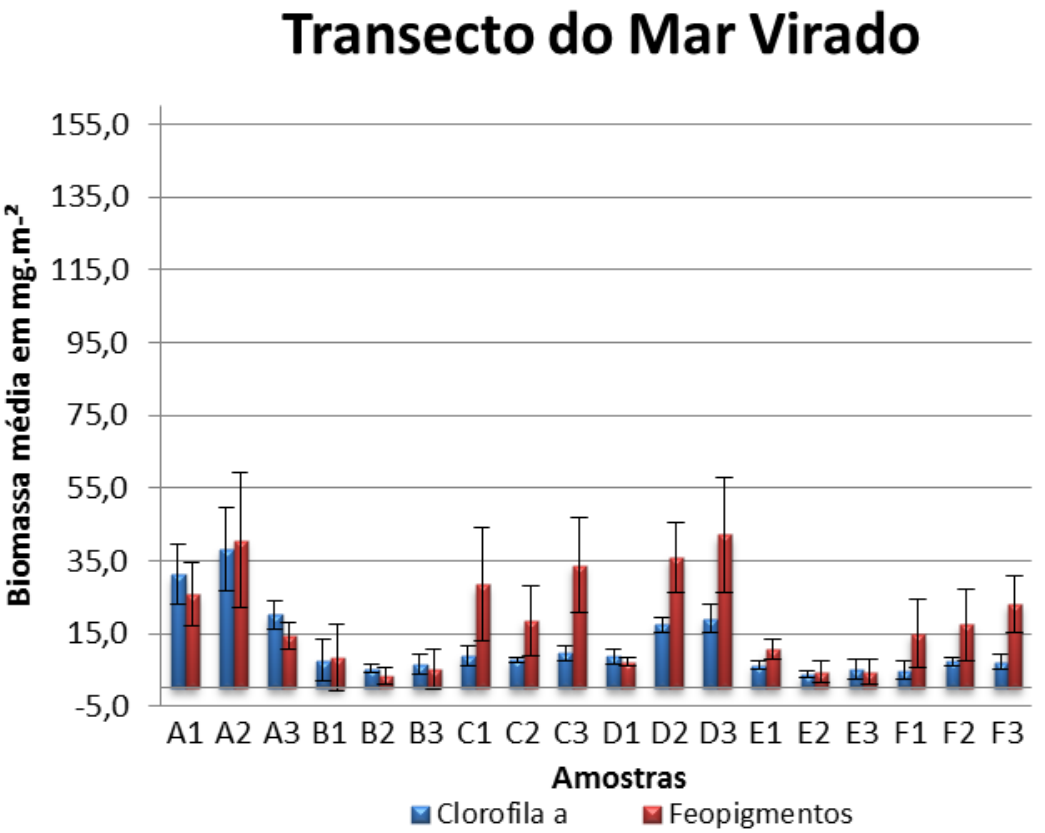

Figura 13 a: Distribuição da biomassa média microfitobentônica por amostras no transecto do Mar Virado (verão de 2013).

\section{Transecto do Mar Virado}

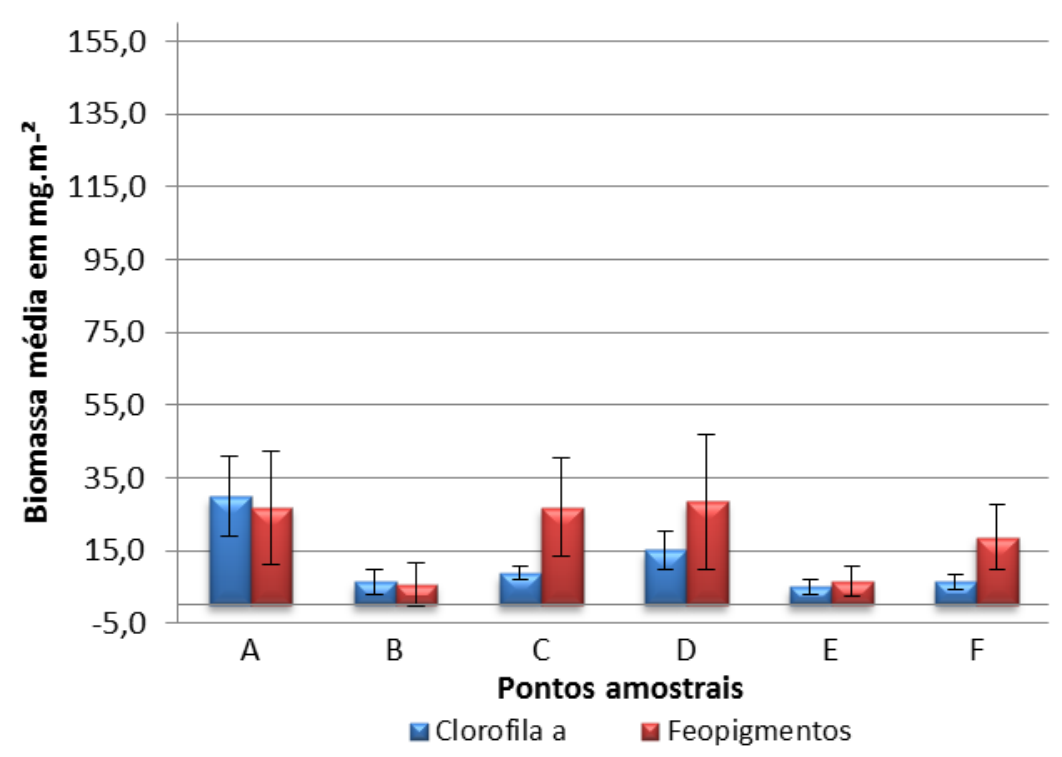

Figura 13 b: Distribuição da biomassa média microfitobentônica por pontos amostrais no transecto do Mar Virado (verão de 2013).

Ao comparar a distribuição da biomassa do microfitobentos para a amostragem do verão de 2013 do transecto do Mar Virado (Tab. 30 e Fig. 13 
b), o teste estatístico considerou os pontos amostrais significativamente diferentes para clorofila a $(p=0,0000)$ e para feopigmentos $(p=0,0000)$.

A comparação múltipla para os pontos amostrais do transecto do Mar Virado formou dois grupos distintos para clorofila a $\underline{a}$, onde o grupo de maior biomassa foi formado pelos pontos amostrais $A$ e $D$ e sem associação com 0 grupo de menor biomassa; enquanto o grupo de menor biomassa foi formado pelos pontos amostrais $\mathrm{C}, \mathrm{B}, \mathrm{F}$ e E. Para feopigmentos também foram formados dois grupos distintos, onde os pontos amostrais $D, A, C$ e $F$ formaram o grupo de maior teor; enquanto o grupo de menor teor foi formado pelos pontos amostrais E e B sem associação entre os grupos. (Tab. 30).

Tabela 30: Resultados do Teste de Kruskal-Wallis $(\alpha<0,05)$, com a comparação múltipla (do tipo Tukey) de Nemenyi para a amostragem do verão de 2013 do transecto do Mar Virado.

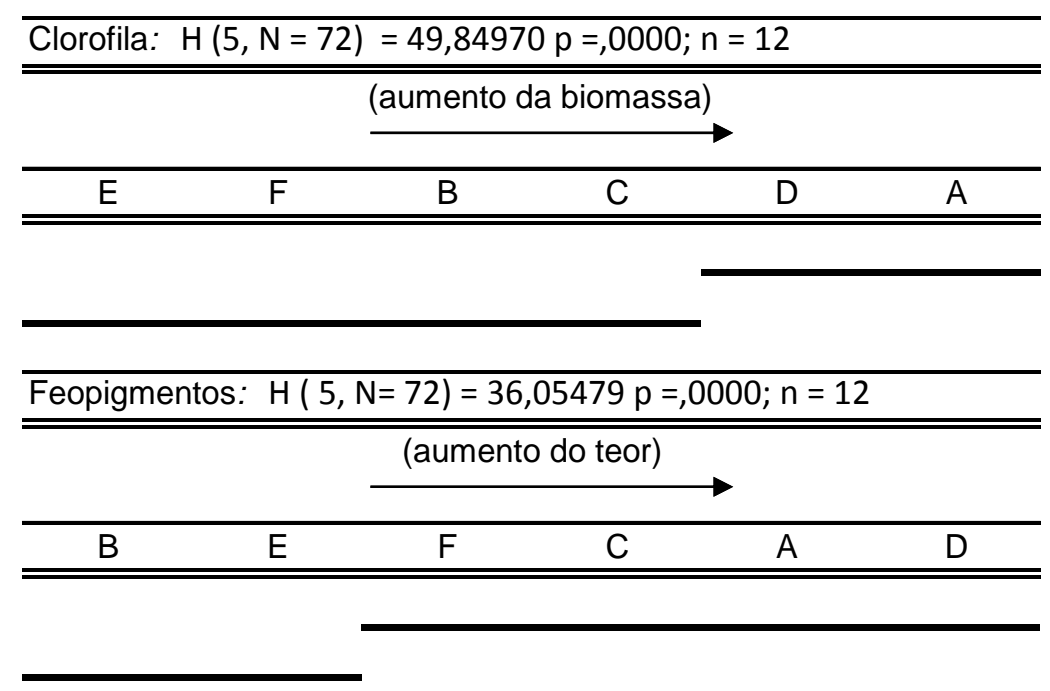

Clorofila a se correlacionou positivamente com feopigmentos, irradiância no sedimento, temperatura, carbonato de cálcio, carbono orgânico total e matéria orgânica, enquanto se correlacionou negativamente com profundidade e salinidade, conforme a tabela 31.

Feopigmentos se correlacionaram positivamente com carbonato de cálcio, carbono orgânico total, matéria orgânica e diâmetro médio dos grãos do 
sedimento, enquanto se correlacionaram negativamente com salinidade, conforme a tabela 31 .

O índice de Margalef se correlacionou positivamente com profundidade, salinidade e argila, enquanto se correlacionou negativamente com irradiância no sedimento, temperatura, carbono orgânico total e matéria orgânica, conforme a tabela 31 .

A razão $\mathrm{cl} \underline{\text { a }}$ se correlacionou positivamente com irradiância no sedimento e temperatura, enquanto se correlacionou negativamente com profundidade, diâmetro médio dos grãos do sedimento e argila, conforme a tabela 31.

Tabela 31: Correlações $(N=72)$ de Spearman $(r)$, entre as variáveis avaliadas para a amostragem do verão de 2013 do transecto do Mar Virado.

\begin{tabular}{c|c|c}
\hline Variáveis & Spearman & p-nível \\
\hline Clorofila a X Feopigmentos & 0,752 & 0,000000 \\
\hline Clorofila a X Profundidade & $-0,491$ & 0,000012 \\
\hline Clorofila a X Irradiância no sedimento & 0,291 & 0,013225 \\
\hline Clorofila a X Salinidade & $-0,700$ & 0,000000 \\
\hline Clorofila a X Temperatura & 0,491 & 0,000012 \\
\hline Clorofila a X CaCO ${ }_{3}$ & 0,349 & 0,002687 \\
\hline Clorofila a X Carbono orgânico total & 0,763 & 0,000000 \\
\hline Clorofila a X Matéria orgânica & 0,763 & 0,000000 \\
\hline Feopigmentos X Salinidade & $-0,422$ & 0,000218 \\
\hline Feopigmentos X CaCO & 0,349 & 0,002655 \\
\hline Feopigmentos X Carbono orgânico total & 0,571 & 0,000000 \\
\hline Feopigmentos X Matéria orgânica & 0,571 & 0,000000 \\
\hline Feopigmentos X Diâmetro médio dos grãos do sedimento & 0,376 & 0,001147 \\
\hline Margalef X Profundidade & 0,434 & 0,000140 \\
\hline Margalef X Irradiância no sedimento & $-0,349$ & 0,002624 \\
\hline Margalef X Salinidade & 0,398 & 0,000532 \\
\hline Margalef X Temperatura & $-0,434$ & 0,000140 \\
\hline Margalef X Carbono orgânico total & $-0,263$ & 0,025634 \\
\hline Margalef X Matéria orgânica & $-0,263$ & 0,025634 \\
\hline Margalef X Argila & 0,281 & 0,016816 \\
\hline Cl a / Feo X Profundidade & $-0,503$ & 0,000007 \\
\hline Cl a / Feo X Irradiância no sedimento & 0,533 & 0,000001 \\
\hline Cl a / Feo X Temperatura & 0,503 & 0,000007 \\
\hline Cl a $/$ Feo X Diâmetro médio dos grãos do sedimento & $-0,468$ & 0,000034 \\
\hline Cl a / Feo X Argila & $-0,600$ & 0,000000 \\
\hline
\end{tabular}




\section{4. Comparação entre os transectos}

A tabela 32 apresenta os valores médios, desvios padrão de clorofila a feopigmentos, índices de Margalef e razão cl a / feo para os transectos estudados. A tabela 33 apresenta os resultados do teste estatístico Kruskal Wallis com a comparação múltipla (do tipo Tukey) de Nemenyi.

Tabela 32: Valores das médias e dos desvios padrão amostrais de clorofila a $\left(\mathrm{mg} \cdot \mathrm{m}^{-2}\right)$, feopigmentos $\left(\mathrm{mg} \cdot \mathrm{m}^{-2}\right)$, índice de Margalef e razão $\mathrm{cl} \underline{\mathrm{a}} / \mathrm{feo}$ para a comparação entre os transectos da amostragem do verão de 2013 $\left(\mathrm{N}_{\text {transecto }}=72 ; \mathrm{N}_{\text {região }}=216\right)$.

\begin{tabular}{c|c|c|c|c|c|c|c|c}
\hline & \multicolumn{2}{|c|}{ Clorofila $\underline{\underline{a}}$} & \multicolumn{2}{c|}{ Feopigmentos } & \multicolumn{2}{c|}{ Margalef } & \multicolumn{2}{c}{$\mathrm{Cl}$ a / feo } \\
\hline Transectos & Média & Desvio & Média & Desvio & Média & Desvio & Média & Desvio \\
\hline FLA & 18,5 & 11,4 & 28,4 & 16,2 & 4,2 & 0,8 & 0,7 & 0,4 \\
\hline FOR & 11,8 & 11,3 & 13,7 & 13,6 & 4,1 & 0,9 & 1,2 & 1,7 \\
\hline MV & 11,9 & 10,2 & 18,8 & 15,2 & 4,3 & 0,8 & 0,9 & 0,8 \\
\hline $\begin{array}{c}\text { Região de } \\
\text { Ubatuba }\end{array}$ & 14,1 & 11,3 & 20,3 & 16,2 & 4,2 & 0,8 & 1,0 & 1,1 \\
\hline
\end{tabular}

Para a região de Ubatuba, os teores médios dos pigmentos foram de $14,1 \pm 11,3 \mathrm{mg} \cdot \mathrm{m}^{-2}$ para clorofila a e de 20,3 \pm 16,2 $\mathrm{mg} \cdot \mathrm{m}^{-2}$ para feopigmentos. A média do índice de Margalef foi de 4,2 $\pm 0,8$, enquanto a média da razão $\mathrm{cl} \underline{\mathrm{a}}$ / feo foi de 1,0 $\pm 1,1$, conforme a tabela 32 .

Para o transecto do Flamengo, os teores médios dos pigmentos foram de $18,5 \pm 11,4 \mathrm{mg} \cdot \mathrm{m}^{-2}$ para clorofila $\underline{\text { a }}$ e de $28,4 \pm 16,2 \mathrm{mg} \cdot \mathrm{m}^{-2}$ para feopigmentos. Para o transecto da Fortaleza, os teores médios dos pigmentos foram de 11,8 \pm 11,3 mg.m $\mathrm{m}^{-2}$ para clorofila a e de 13,7 $\pm 13,6 \mathrm{mg} \cdot \mathrm{m}^{-2}$ para feopigmentos. Para o transecto do Mar Virado, os teores médios dos pigmentos foram de 11,9 $\pm 10,2 \mathrm{mg} \cdot \mathrm{m}^{-2}$ para clorofila a e de 18,8 $\pm 15,2 \mathrm{mg} \cdot \mathrm{m}^{-2}$ para feopigmentos (Tab. 32 e Fig. 14). 


\section{Transectos}

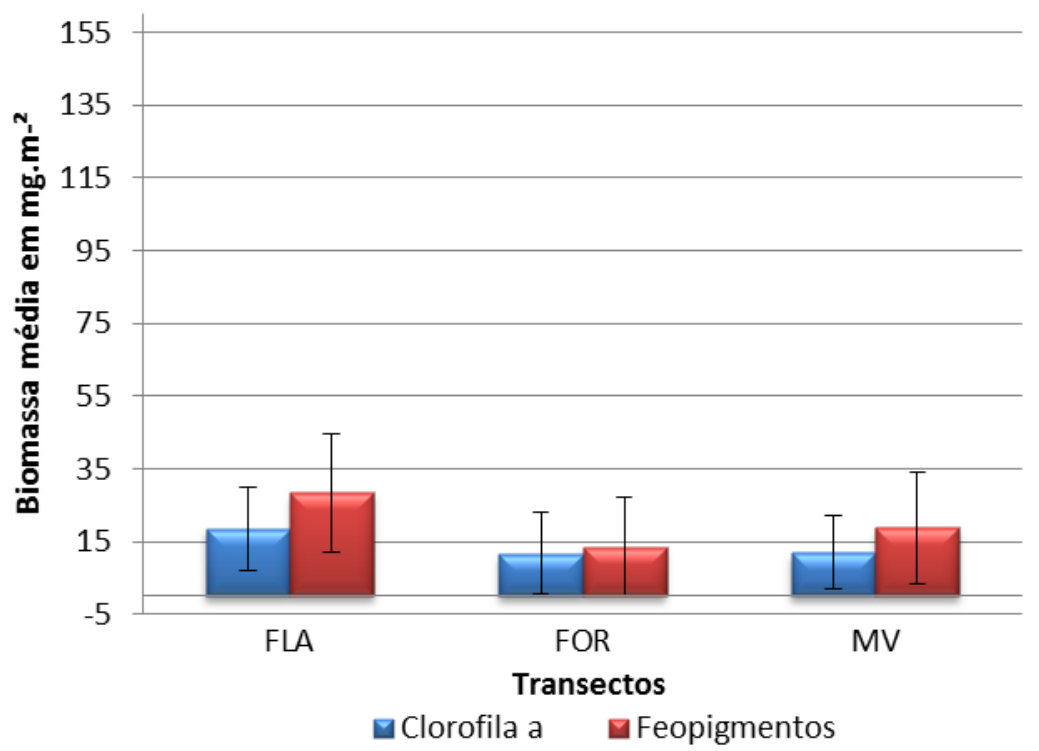

Figura 14: Distribuição da biomassa média microfitobentônica por transectos estudados em Ubatuba (verão de 2013).

Ao comparar a distribuição do microfitobentos nos transectos estudados (Tab. 33 e Fig. 14), o teste estatístico considerou os transectos significativamente diferentes para clorofila $\underline{a}(p=0,0000)$ e para feopigmentos $(p=0,0000)$.

A comparação múltipla dos transectos formou dois grupos distintos para a clorofila $\underline{\text { a }}$; e também foram formados dois grupos distintos para feopigmentos. Tanto para clorofila $\underline{\text { a, }}$ quanto para feopigmentos, o grupo de maiores teores foi formado apenas pelo transecto do Flamengo, sem associação com o grupo de menores teores; enquanto que os transectos do Mar Virado e da Fortaleza formaram o grupo de menores teores de pigmentos (Tab. 33). 
Tabela 33: Resultados do Teste de Kruskal - Wallis $(\alpha<0,05)$, com a comparação múltipla (do tipo Tukey) de Nemenyi para a amostragem do verão de 2013 por transectos estudados em Ubatuba.

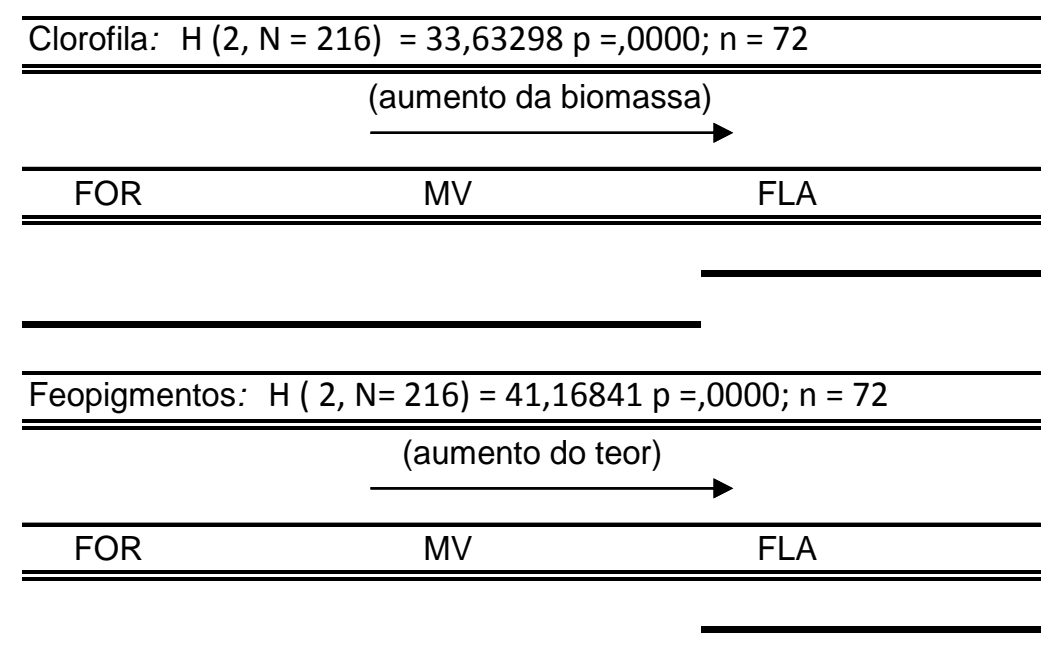

Para a comparação entre os transectos, as correlações foram feitas somente entre clorofila $\underline{a}$, feopigmentos, índice de Margalef e razão cl a / feo. Apenas clorofila a e feopigmentos obtiveram correlação significante $(\alpha<0,5)$, onde apresentaram uma forte correlação positiva $(r=0,812)$. 


\section{DISCUSSÃO}

O microfitobentos é constituído principalmente por diatomáceas, além de fitoflagelados e cianobactérias, distribuindo-se de forma heterogênea no sedimento (Plante-Cuny, 1978; Odum, 2004; Eichler et al., 2006).

No presente estudo foi observado distribuição em manchas da biomassa microfitobentônica. Estas manchas foram observadas pela variação dos valores de biomassa entre as amostras do mesmo ponto amostral. PlanteCuny (1978), Sousa (1985) e David et al. (2009) também associam a variação à distribuição em manchas.

Para a comparação entre os transectos do estudo piloto, as correlações foram feitas somente entre clorofila $\underline{a}$, feopigmentos, índice de Margalef e razão $\mathrm{cl} \underline{\mathrm{a}} / \mathrm{feo}$. Apenas a clorofila $\underline{\mathrm{a}}$ e o teor de feopigmentos apresentaram correlação, sendo ela positiva, corroborando com a relação que normalmente há entre esses pigmentos (Almeida et al., 2009; David et al., 2003, 2009 e 2010).

Para a amostragem do verão de 2013 , os resultados obtidos para a biomassa foram maiores que os observados no estudo piloto para os três transectos. A única exceção ocorreu para o teor médio de feopigmentos do transecto da Fortaleza, onde o resultado foi um pouco maior no estudo piloto comparando-o com o transecto da Fortaleza da amostragem do verão de 2013. Em geral, tanto para o estudo piloto, quanto para a amostragem do verão de 2013 , os maiores valores de clorofila a e feopigmentos foram observados nas regiões mais rasas, as exceções ocorreram para os teores de feopigmentos nos transectos do Flamengo e do Mar Virado, onde não foram maiores nas amostras de $5 \mathrm{~m}$, porém, nessa profundidade ocorreu o segundo teor mais alto de feopigmentos.

É possível notar uma grande variação da biomassa entre os pontos amostrados. Para os três transectos estudados, a maior biomassa ocorreu sempre nas amostras coletadas na profundidade de $5 \mathrm{~m}$.

Para os transectos avaliados no presente estudo, a clorofila a obteve uma correlação positiva com feopigmentos, sendo uma forte correlação $(r=$ $0,828)$ no transecto da Fortaleza. 
Os teores de feopigmentos foram superiores aos teores de clorofila $\underline{a}$ em quase todas as amostras dos transectos do presente estudo. Os feopigmentos associados ao aporte de rio, às algas e aos vegetais mortos, podem sedimentar e acumular-se no sedimento. Em termos gerais, a região estudada tem um hidrodinamismo baixo devido a sua característica geomorfológica (Mahiques, 1992), o que permite sugerir que os feopigmentos são provenientes também de microalgas do plâncton morto que se depositou no bentos, predominando então os teores de feopigmentos sobre clorofila $\underline{a}$ (Plante-Cuny, 1978; Netto et al., 2007 e David et al., 2009).

Os teores médios de clorofila a , de feopigmentos e a razão cl a / feo se correlacionaram negativamente com a profundidade, enquanto se correlacionaram positivamente com irradiância no sedimento. Estes resultados corroboram com os valores de biomassa e de feopigmentos mais altos nas amostras mais rasas, confirmando o declínio da biomassa e de feopigmentos com o aumento da profundidade e consequentemente menor incidência de luz no sedimento.

O índice de Margalef se correlacionou positivamente com a profundidade e negativamente com a irradiância no sedimento, mostrando a tendência de comunidades mais velhas ou senescentes em regiões mais profundas e com menor hidrodinamismo, como observado também por David et al. (2010). Pode-se observar que, em geral, o índice de Margalef cresceu com o aumento de profundidade.

A redução da razão $\mathrm{cl}$ a / feo e o aumento do índice de Margalef, da região mais rasa para a mais profunda é associada à maior taxa fotossintética em águas mais rasas, em função de maior penetração da luz incidente, proporcionando mais luz para a fotossíntese. Segundo Plante-Cuny (1978), valores abaixo ou próximos a 3 para o índice de Margalef indicam comunidades jovens e valores maiores ou próximos a 4 indicam comunidades senescentes.

Além da maior disponibilidade de luz nas regiões mais rasas, em geral, também foram encontrados maiores teores de silte, argila, carbono orgânico total e matéria orgânica. A única exceção foi para o transecto do Mar Virado, onde foram encontrados baixos teores de silte, argila, carbono orgânico total e matéria orgânica. Estas variáveis ambientais se correlacionaram positivamente 
com a biomassa, confirmando a influência que elas têm sobre a comunidade do microfitobentos.

Sousa et al. (1998) e David et al. (2009) observaram correlações positivas entre clorofila a e as variáveis ambientais como nutrientes (nitrogênio, fosfato e enxofre) e matéria orgânica. Sumida et al. (2005) estudaram o microfitobentos em Ubatuba e em Cabo Frio e observaram que em Ubatuba ocorreu um declínio da clorofila a com o aumento da profundidade, enquanto que em Cabo Frio observaram um efeito um pouco diferente, ocorrendo um aumento de clorofila a entre as isóbatas de 40 e $100 \mathrm{~m}$ e posteriormente um declínio até a isóbata de $500 \mathrm{~m}$. Este fato foi explicado pela presença das águas ricas provenientes da ressurgência, influenciando portanto, na biomassa da isóbata de $100 \mathrm{~m}$, principalmente durante o verão quando a ACAS atinge essa região. Portanto, os nutrientes influenciam positivamente 0 microfitobentos, pois a presença de nutrientes permite o desenvolvimento dessa comunidade (Cibic et al., 2007 a). Não foram analisadas amostras de nutrientes no presente estudo, porém, os nutrientes podem ser mineralizados a partir da matéria orgânica disponível. Esta sempre se correlacionou positivamente com o microfitobentos.

A biomassa se correlacionou positivamente com o diâmetro médio dos grãos do sedimento, enquanto se correlacionou negativamente com os grânulos e a areia. Estas variáveis têm relação direta com a biomassa, onde geralmente grânulos e areia tendem a se correlacionar negativamente com 0 microfitobentos, pois este tem preferência por sedimentos mais finos como silte e argila. Silte e argila têm maior probabilidade de acumular matéria orgânica e carbono orgânico total como verificado no presente estudo, onde, em geral, nas amostras de profundidades menores foram encontrados os maiores teores de matéria orgânica e carbono orgânico total, provavelmente, disponibilizando nutrientes indispensáveis para o crescimento do microfitobentos.

Foram observados maiores teores de carbonato de cálcio nas amostras de maiores teores de silte e argila, isto é, sedimentos mais finos. O carbonato de cálcio faz parte da composição do sedimento biogênico. No presente estudo, houve uma baixa correlação entre biomassa e carbonato de cálcio, mas sempre uma correlação positiva. David et al. (2003) afirmaram que manter o carbonato de cálcio nas amostras, ao invés de eliminá-lo para a realização da 
análise granulométrica, pode melhor representar o ambiente em que as algas vivem.

Quanto à salinidade e pouca variação dessa variável, esta não deve ter influenciado a distribuição das microalgas bentônicas para essa região.

A temperatura apresentou uma correlação positiva com os teores de clorofila a e de feopigmentos, refletindo os valores medidos em campo, onde temperatura foi maior nas amostras mais rasas, com variações de até $8 \stackrel{\circ}{ } \mathrm{C}$. Facca \& Sfriso (2007) afirmam que a distribuição das diatomáceas bentônicas é influenciada positivamente pela temperatura, mas apenas secundariamente. Para o presente estudo, não foi realizada uma análise sazonal da distribuição da biomassa do microfitobentos. Vale ressaltar que quando ocorre uma correlação, não significa exatamente um resultado de causa e efeito, mas pode ser uma simples combinação matemática, nesse caso não influenciando a distribuição do microfitobentos.

Cahoon et al. (1999) observaram que a biomassa microfitobentônica em estuário e a proporção de sedimentos finos apresentaram uma correlação negativa, talvez devido o aumento da turbidez através do maior transporte de sedimentos finos ou muito finos. Estes autores também sugerem que o esgoto, o enriquecimento de praia e o transporte de sedimentos finos podem reduzir a produtividade biológica de ecossistemas de águas rasas, enquanto Cahoon et al. (2012) observaram que o aumento da biomassa em praias é associado com sedimentos mais finos e enriquecimento dos mesmos por matéria orgânica, e afirmaram que a matéria orgânica aumenta a biomassa apenas temporariamente e não a longo prazo.

Skowronski et al. (2009) observaram correlações negativas para a clorofila a e os teores de feopigmentos com a profundidade, o que relacionaram com a menor disponibilidade de luz no sedimento para amostras de maior profundidade.

Corbisier et al. (1997), Blackford (2002), Cibic et al. (2007 b), Facca \& Sfriso (2007) e Loassachan et al. (2009) consideram que a intensidade luminosa é o fator mais importante para a comunidade microfitobentônica, uma vez que o sedimento é, em geral, rico em nutrientes. Portanto, quando a irradiância é adequada para fotossíntese, há um crescimento da comunidade 
do microfitobentos, levando a um aumento da biomassa (Loassachan et al., 2009).

Em geral, no verão de 2013 do presente estudo, os maiores teores de clorofila a e de feopigmentos ocorreram nas regiões mais rasas, ocasionando fortes correlações negativas com a profundidade, ou no mínimo uma correlação negativa. Portanto, quanto menor a profundidade, maior a porcentagem de luz incidente que chega ao sedimento, o que proporciona um maior crescimento do microfitobentos.

Além da luz, a matéria orgânica e o carbono orgânico total também foram muito importantes para a distribuição do microfitobentos no presente estudo. Na amostragem do verão de 2013 do transecto do Mar Virado, foi verificada uma maior biomassa nos pontos de 20 e $25 \mathrm{~m}$, onde foram observados maiores teores de matéria orgânica e carbono orgânico total em relação aos pontos de 10 e $15 \mathrm{~m}$. Portanto, estas variáveis influenciaram positivamente sobre a biomassa microfitobentônica.

Quanto à biomassa do presente estudo, foram feitas comparações com trabalhos de outros ambientes, como a Praia de Pernambuco no Guarujá, a Praia Comprida em Santa Catarina e o estuário do Canal de Bertioga estudados por David et al. (2003), Netto et al. (2007) e Eichler et al. (2006) respectivamente.

O teores médios de clorofila a e de feopigmentos observados nos transectos do presente trabalho foram maiores que os encontrados por David et al. (2003) na Praia de Pernambuco, Guarujá, onde os valores variaram entre 2,13 e $7,58 \mathrm{mg} \cdot \mathrm{m}^{-2}$ para clorofila a e entre 0,03 e $0,54 \mathrm{mg} \cdot \mathrm{m}^{-2}$ para feopigmentos.

Os valores médios de clorofila $\underline{a}$ observados nos transectos do Flamengo, da Fortaleza e do Mar Virado foram menores que os observados por Netto et al. (2007) na Praia Comprida, Santa Catarina, quando os valores médios foram de $321,25 \mathrm{mg} \cdot \mathrm{m}^{-2}$ para a zona entremarés e de $657 \mathrm{mg} \cdot \mathrm{m}^{-2}$ para a zona sublitoral, enquanto os valores médios de feopigmentos que variaram de aproximadamente 180 a $700 \mathrm{mg} \cdot \mathrm{m}^{-2}$ entre as amostras também foram maiores que os observados nos transectos do presente estudo.

Os valores médios de clorofila a nos transectos estudados do presente estudo foram menores que o valor médio observado no Canal de Bertioga por 
Eichler et al. (2006) durante o inverno, onde foi observado $25,1 \pm 4,8 \mathrm{mg} \cdot \mathrm{m}^{-2}$, enquanto $o$ teor médio de feopigmentos $\left(13,5 \pm 1,8 \mathrm{mg} \cdot \mathrm{m}^{-2}\right)$ foi mais alto que 0 observado no transecto da Fortaleza e mais baixo que os observados nos transectos do Flamengo e do Mar Virado. Para a amostragem realizada no verão, Eichler et al. (2006) encontrou valores mais altos para clorofila a $(43,6 \pm$ 4,8 $\left.\mathrm{mg} \cdot \mathrm{m}^{-2}\right)$ e também para feopigmentos $\left(51,5 \pm 12,5 \mathrm{mg} \cdot \mathrm{m}^{-2}\right)$ em relação aos observados nos transectos do presente estudo. Em geral, os valores encontrados por Eichler et al. (2006) foram mais altos, estes podem estar associados a maior quantidade de nutrientes por ser um ecossistema estuarino, enquanto o presente estudo foi realizado no ambiente marinho.

Quanto à biomassa relacionada à profundidade e à luminosidade, o presente estudo foi comparado com trabalhos realizados na zona sublitoral por Almeida et al. (2009), David et al. (2009 e 2010) e Skowronski et al. (2009).

Os valores médios dos pigmentos observados no transecto do Flamengo foram maiores que os encontrados por Almeida et al. (2009) e David et al. (2010) na Enseada de Boiçucanga, São Sebastião, onde foram encontrados valores médios de 16,7 $\pm 10,5 \mathrm{mg} \cdot \mathrm{m}^{-2}$ para clorofila a e de 18,5 \pm $24,4 \mathrm{mg} \cdot \mathrm{m}^{-2}$ para feopigmentos. No transecto da Fortaleza, os valores observados foram menores, tanto para clorofila a $\underline{a}$, quanto para feopigmentos em relação aos observados na Enseada de Boiçucanga. No Mar Virado os valores foram menores apenas para clorofila $\underline{a}$, enquanto $o$ valor médio de feopigmentos foi maior que o observado na Enseada de Boiçucanga.

No presente estudo ocorreu correlação negativa entre clorofila a e a profundidade e entre feopigmentos e profundidade, enquanto Almeida et al. (2009) e David et al. (2010) observaram uma correlação positiva de clorofila a e feopigmentos com o aumento da profundidade para a Enseada de Boiçucanga, São Sebastião, considerando as profundidades amostrais de 8,5, 11,5, 14,4 e 17,5 m. Estes resultados são explicados pelo hidrodinamismo, pois, a Enseada de Boiçucanga apresenta uma praia de tombo, onde a força hidrodinâmica é muito forte próxima aos pontos de 8,5 e 11,5 m de profundidade e menor nos pontos de 14,4 e 17,5 m, onde diminui a capacidade das ondas movimentarem partículas nessas profundidades (Plante-Cuny, 1978; David et al., 2009).

David et al. (2009) analisaram amostras de inverno e verão em quatro regiões: Praia Grande, Baía de Santos, Guarujá e Canal de São Sebastião. 
Em relação à Praia Grande, os teores médios dos pigmentos observados foram de 11,6 \pm 3.3 (verão) e 11,8 \pm 8,1 mg.m² (inverno) para clorofila a; e de 7,9 \pm 3,7 (verão) e 9,6 \pm 6,0 mg.m² (inverno) para os feopigmentos. Portanto, os valores foram menores que aqueles observados nos transectos do presente estudo. Houve uma única exceção, onde o transecto da Fortaleza obteve teor de clorofila a igual aquele observado na Praia Grande durante o inverno (11,8 \pm 8,1 mg.m²).

Para a Baía de Santos, os autores observaram que os teores médios dos pigmentos variaram entre 19,7 \pm 7,5 (verão) e 30,5 $\pm 7,4$ mg.m- ${ }^{2}$ (inverno) para clorofila a ; e entre 17,4 \pm 9,7 (verão) e 55,0 $\pm 20,0$ mg.m- ${ }^{2}$ (inverno) para feopigmentos. Portanto, a clorofila $\underline{a}$ foi maior que a do presente estudo, ocorrendo o mesmo para o teor de feopigmentos, a única exceção foi para a estação de verão, onde o teor de feopigmentos foi menor que os encontrados nos transectos do Flamengo e do Mar Virado.

No Guarujá, os teores médios observados variaram entre 17,9 \pm 5,0 (verão) e 14,9 \pm 4,5 mg.m- ${ }^{2}$ (inverno) para clorofila a ; e entre 15,3 \pm 7,2 (verão) e 23,5 $\pm 8,1 \mathrm{mg} \cdot \mathrm{m}^{-2}$ (inverno) para feopigmentos. Portanto, para clorofila $\underline{\text { a }}$, os valores foram maiores que os observados nos transectos da Fortaleza e do Mar Virado, enquanto o transecto do Flamengo obteve maior biomassa que no Guarujá. Para os feopigmentos, o teor observado no transecto do Flamengo foi maior que o encontrado no Guarujá, enquanto o teor de feopigmentos da Fortaleza foi menor que o observado no Guarujá e o teor do Mar Virado também foi maior, mas apenas em relação à estação do verão do Guarujá, portanto, foi menor que o valor observado na estação do inverno.

No Canal de São Sebastião, os valores médios observados variaram entre 30,7 \pm 10,6 (verão) e 26,7 \pm 10,6 (inverno) para clorofila a ; e entre 38,2 \pm 21,0 (verão) e 38,4 $\pm 21,2$ mg.m- ${ }^{2}$ (inverno) para feopigmentos. Portanto, tanto a clorofila $\underline{\text { a }}$, quanto para feopigmentos, os valores médios observados nos transectos do presente estudo foram menores que os valores observados no Canal de São Sebastião.

David et al. (2009) não encontraram correlação entre clorofila a e profundidade e entre feopigmentos e profundidade. Porém, associaram o aumento dos teores de clorofila $\underline{\text { a }}$ e de feopigmentos com menores forças hidrodinâmicas. Além disso, nas amostras de locais mais profundos, os teores 
de feopigmentos foram maiores que os teores de clorofila a. Para o presente estudo, a proporção de feopigmentos em relação à clorofila a também foi maior nas amostras de locais mais profundos dos transectos do Flamengo e do Mar Virado, a única exceção ocorreu no transecto da Fortaleza. Isso é explicado pela menor taxa fotossintética realizada em profundidades maiores onde a disponibilidade de luz no sedimento é menor.

Os teores médios dos pigmentos observados nos transectos do presente estudo foram menores que os observados por Skowronski et al. (2009) na Enseada Martel, Ilha Rei George, Antártica, quano os valores médios dos pigmentos foram de $71,5 \mathrm{mg} \cdot \mathrm{m}^{2}$ para a clorofila a e de $142,9 \mathrm{mg} \cdot \mathrm{m}^{2}$ para feopigmentos. Os valores observados por Skowronski et al. (2009) foram superiores aos do estudo atual, provavelmente devido a alta produtividade do verão antártico, onde a presença de nutrientes em abundância e a luminosidade induzem o aumento da biomassa.

Skowronski et al. (2009) observaram uma redução da razão cl a / feo da região mais rasa $(3,2 \pm 3,2)$ para a mais profunda $(0,7 \pm 1,0)$. Também observaram uma forte correlação negativa $(r=-0,87)$ para a clorofila a com aumento da profundidade e uma correlação negativa $(r=-0,68)$ para os feopigmentos com a profundidade. Dessa forma, corroborando com os resultados obtidos no presente estudo.

Os resultados obtidos nos transectos do presente estudo corroboram com os resultados obtidos por Almeida et al. (2009), David et al. (2009), Skowronski et al. (2009) e David et al. (2010), onde foi verificado que, em geral, as amostras de maiores teores de clorofila a e de feopigmentos ocorreram em regiões onde o hidrodinamismo é menor, nesse caso dentro das enseadas do Flamengo, da Fortaleza e do Mar Virado. Não foi realizado um estudo de correntes no estudo atual, mas provavelmente há uma menor atividade hidrodinâmica junto ao fundo nos pontos de coleta dentro das enseadas devido à geomorfologia local.

Vale ressaltar que os valores obtidos são resultados da combinação de diversos fatores, então as demais variáveis ambientais que se correlacionaram positivamente com a clorofila a e com os feopigmentos, como o carbono orgânico total, a matéria orgânica, o diâmetro médio dos grãos do sedimento e os teores de silte e argila também são muito importantes para avaliar a 
distribuição do microfitobentos, enquanto os teores de grânulos e areia tendem a limitar o crescimento da comunidade microfitobentônica. 


\section{CONCLUSÕES}

Os teores médios de clorofila a e de feopigmentos foram maiores no transecto do Flamengo e menores no transecto do Mar Virado e da Fortaleza.

Os teores médios de clorofila a e de feopigmentos foram maiores nas regiões mais rasas.

Houve distribuição em manchas, estas foram observadas nas próprias amostras e entre as amostras do mesmo ponto amostral.

A variável ambiental mais importante para a distribuição da biomassa microfitobentônica foi a disponibilidade de luz no sedimento. Esta influenciou positivamente, enquanto a profundidade influenciou negativamente na distribuição da biomassa.

A matéria orgânica e o carbono orgânico total também foram muito importantes para a distribuição do microfitobentos, pois foi verificada uma correlação positiva entre a biomassa e os teores de matéria orgânica e de carbono orgânico total. Portanto, estas variáveis influenciaram positivamente sobre a biomassa microfitobentônica.

Vale ressaltar que os valores obtidos são resultados da combinação de diversos fatores, então as demais variáveis ambientais que se correlacionaram positivamente com a clorofila a e com os feopigmentos, como o diâmetro médio dos grãos do sedimento e os teores de silte e argila também são muito importantes para avaliar a distribuição do microfitobentos, enquanto os teores de grânulos e areia tendem a limitar o crescimento da comunidade microfitobentônica. 


\section{REFERÊNCIAS BIBLIOGRÁFICAS}

ALMEIDA, C. S.; SOUSA, E. C. P. M.; ROMEIRO, D.; CARVALHO. A. P. C. \& DAVID, C. J. 2009. Distribuição do Microfitobentos na Enseada de Boiçucanga, São Sebastião, SP. In: Cooperação entre professores e estudantes no processo da pesquisa: VI Encontro de Iniciação Científica da Uninove. Gráfica Uninove, p. 19 - 20.

BARRANGUET, C. 1997. The role of microphythobenthic primary production in the Mediterranean mussel culture area. Estuarine, Coastal abd Shelf Science, v. 44, p. $753-765$.

BLACKFORD, J. C. 2002. The Influence of microphytobenthos on the Northern adriatic ecosystem: A modelling study. Estuarine, Coastal and Shelf Science, v. 55 , p. $109-123$.

BUSCAIL, R. \& GERMAIN, C. 1997. Present-day organic matter sedimentation on the NW Mediterranean margin: importance of off-shelf export. Limnology and Oceanography, v. 42 (2), p. 217 - 229.

CAHOON, L. B.; REDMAN, R. S. \& TRONZO, C. R. 1990. Benthic microalgal biomass in sediments of Onslow Bay, North Carolina, USA. Marine Ecology Progress Series, v. 84, p. 185 - 196.

CAHOON, L. B. 1999. The role of benthic microalgae in neritic ecosystems. Oceanography and Marine Biology: na Annual Review, v. 37, p. 47 - 86.

CAHOON, L. B.; NEARHOOF, J. E. \& TILTON, C. L. 1999. Sediment grain size effect on benthic microalgal biomass in shallow aquatic ecosystems. Estuaries, v. $22(3 \mathrm{~B})$, p. 735 - 741. 
CAHOON, L. B.; CAREY, E. S. \& BLUM, J. E. 2012. Benthic microalgal biomass on ocean beaches: Effects of sediment grain size and beach renourishment. Journal of Coastal Research, v. 28 (4), p. 853 - 859.

CIBIC, T.; BLASUTTO, O.; FALCONI, C. \& UMANI, S. F. 2007 a. Microphytobenthic biomass, species composition and nutrient availability in sublittoral sediments of the Gulf of Trieste (northern Adriatic Sea). Estuarine, Coastal and Shelf Science, v. 75, p. 50 - 62.

CIBIC, T.; BLASUTTO, O.; HANCKE, K \& JOHNSEN, G. 2007 b. Microphytobenthic species composition, pigment concentration and primary production in sublittoral sediments of the Trondheimsfjord (Norway). Journal of Phycology, v. 43, p. 1126 - 1137.

CORBISIER, T. N.; SOUSA, E. C. P. M. \& EICHLER, B. B. 1997. Distribuição espacial do meiobentos e do microfitobentos na Enseada do Flamengo, Ubatuba, São Paulo. Revista Brasileira de Biologia, v. 57 (1), p. 109 - 119.

DAVID, C. J. 1997. Contribuição para o estudo da distribuição do microfitobentos da região entremarés de praias da Baixada Santista, Estado de São Paulo. Dissertação de mestrado. Instituto Oceanográfico da Universidade de São Paulo, Departamento de Oceanografia Biológica. 155p.

DAVID, C. J. 2003. Distribuição da biomassa microfitobentônica na Baía de Santos (SP, Brasil) com ênfase para a região do emissário submarino. Aspectos da produção primária e da florística. Tese de doutorado. Instituto Oceanográfico da Universidade de São Paulo, Departamento de Oceanografia Biológica. 222 p.

DAVID, C. J.; SKOVRONSKI, R. S. P.; SOUSA, E. C. P. M.; GUISELLI, R. O.; CORBISIER, T. N.; EICHLER, B. B. 2003. Microphytobenthic biomass gradient along the beach face and along shore profiles at Pernambuco Beach, Guarujá SP, Brazil. Journal of Coastal Research, v. 35, p. 426 - 430. 
DAVID, C. J.; SOUSA, E. C. P. M. \& TOMMASI, L. R. 2009. Microphytobenthic biomass in the coastal region of Baixada Santista and São Sebastião Chanel, SP, BR: LOESS Project. In: BRAGA, E. S. (Org). Oceanografia e Mudanças Globais - Proceedings do III Simpósio Brasileiro de Oceanografia. v.1, p. 133 144.

DAVID, C. J.; ALMEIDA, C. S.; SOUSA, E. C. P. M.; CARVALHO, A. P. C. \& SERRA, A. L. 2010. Distribuição microfitobentônica no perfil batimétrico da Enseada de Boiçucanga, São Sebastião, SP. In: Formação Científica como Fator de Inovação e Mobilidade Social: IV Seminário Nacional de Pesquisa da Uninove. Gráfica Uninove. p. 01 - 05.

DAY JR., J. W.; HALL, C. A. S.; KEMP, W. M. \& YANEZ-ARANCIBIA, A. 1989. Estuarine Ecology. New York. Wiley. 558 p.

DE JONGE, V. N. \& BEUSEKOM, J. V. 1992. Contribuition of resuspended microphytobenthos to total phytoplankton in the Ems estuary and its possible role for grazers. Nether Journal of Sea Research, v. 30, p. 91 - 105.

DHN. 1983. Carta Náutica oํ 1635 - Da llha das Couves à llha do Mar Virado. 1‥ ed., São Paulo.

EICHLER, P. P. B.; EICHLER, B. B.; DAVID, C. J.; MIRANDA, L. B.; SOUSA, E. C. P. M. 2006. The estuary ecosystem of Bertioga, São Paulo, Brazil. Journal of Coastal Research, v. 39, p. 1110 - 1113.

FACCA, C. \& SFRISO, A. 2007. Epipelic diatom spatial and temporal distribution and relationship with the main environmental parameters in coastal waters. Estuarine, Coastal and Shelf Science, v. 75, p. 35 - 49.

FOLK, L. R. \& WARD, W. C. 1957. Brazos river bar: a study in the significance of grain size parameters. Journal of Sedimentary Petrology, v. 27, p. 3 - 26. 
GAUDETTE, H. E.; FLIGHT, W; TOWER, L. \& FOLGER, D. W. 1974. An inexpensive titration method for the determination of organic carbon in recent sediments. Journal of Sedimentary Petrology, v. 44 (1), 249 - 253.

GILLESPIE, P. A.; MAXWELL, P. D. \& RHODES, L. L. 2000. Microphytobenthic communities of subtidal locations in New Zealand: taxonomy, biomass, production, and food-web implications. New Zealand Journal of Marine and Freshwater Research, v. 34, p. 41 - 53.

GRANT, J.; CRANFORD, P. \& EMERSON, C. 1997. Sediment resuspension rates, organic matter quality and food utilization by sea scallops (Placopecten magellanicus) on Georges Bank. Journal of Marine Research, v. 55, p. 965 994.

GUARINI, J. - M.; BLANCHARD, G. F.; GROS, P; GOULEAU, D \& BACHER. 2000. Dynamic model of the short-term variability of microphytobenthic biomass on temperate intertidal mudflats. Marine Ecology Progress Series, v. 195, p. 291 - 303.

GUARINI, J. - M.; CLOERN, J. E.; EDMUNDS, J. \& GROS, P. 2002. Microphytobenthic potential productivity estimated in three tidal embayments of the San Francisco Bay: A comparative study. Estuaries, v. 25 (3), p. 409 - 417.

IBGE. 2014. Cidades: UBATUBA. Disponível em: http://cidades.ibge.gov.br/xtras/perfil.php?codmun=355540. Visualizado em 03 de abril de 2014.

KELLY, J. A.; HONEYWILL, C. \& PATERSON, D. M. 2001. Microscale analysis of chlorophyll-a in cohesive, intertidal sediments: implications of microphytobenthos distribution. Journal of the Marine Biological Association of the United Kingdom, v. 81, p. 151 - 162. 
KUNIHIRO, T.; SHIBATA, J.; HAMAOKA, H.; SOGABE, A.; MORIYA, K.; KUWAE, M.; ITO, K.; KATAYAMA, A.; TSUTSUMI, H. \& OMORI, K. 2012. Relative biomass of bacteria and microphytobenthos in surface sediments of the Seto Inland Sea of Japan. Interdisciplinary Studies on Environmental Chemistry - Environmental Pollution and Ecotoxicology, p. 397 - 406.

LOASSACHAN, N.; ICHIMI, K. \& TADA, K. 2009. Evidence of Microphytobenthic Roles on Coastal Shallow Water of the Seto Inland Sea, Japan. Journal of Oceanography, v. 65, p. 361 - 372.

MACINTYRE, H, L.; GEIDER, R. J. \& MILLER, D. C. 1996. Microphytobenthos: The ecological role of the "Secret Garden" of unvegetated, shalow-water marine habitats. I. Distribuition, abundance and primary production. Estuaries, v. 19 (2), p. $186-201$.

MAHIQUES, M. M. 1987. Considerações sobre os sedimentos de superfície de fundo da Baía da llha Grande, Estado do Rio de Janeiro. Dissertação de mestrado. Instituto Oceanográfico da Universidade de São Paulo, Departamento de Oceanografia Física, Química e Geológica, v. 1, 177 p.

MAHIQUES, M. M. 1992. Variações temporais na sedimentação quaternária dos embaiamentos da região de Ubatuba, Estado de São Paulo. Tese de Doutorado. Instituto Oceanográfico da Universidade de São Paulo, Departamento de Oceanografia Física, Química e Geológica, v. 1, 129 p.

MARGALEF, R. 1974. Ecologia. Barcelona: Omega. 951 p.

MILLER, D. C.; GEIDER, R. J. \& MACINTYRE, H, L. 1996. Microphytobenthos: The ecological role of the "Secret Garden" of unvegetated, shalow-water marine habitats. II. role in sediment stability and shallow-water food webs. Estuaries, v. 19 (2), p. $202-212$. 
MONTAGNA, P. A. 1984. In situ mensurement of meiobenthic grazing rates on sediment bacteria and adaphic diatoms. Marine Ecology Progress Series, v. 18, p. $119-130$.

NELSON, J. R.; ECKMAN, J. E.; ROBERTSON, C. Y.; MARINELLI, L. R. \& JAHNKE, R. A. 1999. Benthic microalgal biomass and irradiance at the sea floor on the continental shelf of the South Atlantic Bight: Spatial and temporal variability and storm effects. Continental Shelf Research, v. 19, p. 477- 505.

NETTO, S. A.; PAGLIOSA, P. R.; FONSECA, A. L. O.; GALLUCCI, F.; FONSECA, G. F. C. \& SOUZA, R. S. 2007. Interações entre microfitobentos, meiofauna e macrofauna (Praia Cumprida, Santa Catarina). Brazilian Journal of Ecology, v. 1, p. 78 - 82.

ODUM, E. P. 2004. Fundamentos da Ecologia. 6ª edição. Lisboa. Fundação Calouste Gulbenkian. 927 p.

PALMER, J. D. \& ROUND, F. E. 1965. Persistent vertical migration rhythms in benthic microflora. Journal of the Marine Biological Association of the United Kingdom, v. 45, p. 567 - 582.

PELLIZARI, F.; BORZONE, C. A.; PEZZUTO, P. R. \& ZEHNDER-ALVES L. 2005. The contribution of microphytobenthos for scallop Euvola ziczac (Bivalvia: Pectinidae) feeding in a shallow area of the south-eastern Brazilian continental shelf. Journal of the Marine Biological Association of the United Kingdom, v. 85, p. 961 - 967.

PLANTE-CUNY, M. R. 1978. PLANTE-CUNY, M. R. 1978. Pigments photosynthétiques et production primaire des fonds meubles néritiques d'une région tropicale (Nosy-Bé, Madagascar). Paris, Office de la Recherche Scientifique et Technique Outre-Mer, 96, 359 p. 
POOLE, H. H. \& ATIKINS, R. G. 1929. Photoeletric measurements of submarine illumination throughout the year. Journal of the Marine Biological Association of the United Kingdom, v. 16, p. 297 - 324.

RIVKIN, R. B. \& PUTT, M. 1987. Photosynthesis and cell division by Antarctic microalgae: comparison of benthic, planktonic and ice algae. Journal of Phycology, v. 23, p. 223 - 229.

ROUND, F. E. 1981. The ecology of algae. Cambridge. Cambridge University Press. $653 \mathrm{p}$.

ROUND, F. E.; CRAWFORD, R. M. \& MANN, D. G. 1990. The diatoms. Cambridge. Cambridge University Press. 747 p.

SABUROVA, M. A. \& POLIKARPOV, I. G. 2003. Diatom activity within soft sediments: behavioural and physiological processes. Marine Ecology Progress Series, v. 251: p. 115 - 126.

SANTOS, P. J. P.; CASTEL, J. \& SOUZA-SANTOS, L. P. 1995. Microphytobenthic patches and their influence on meiofaunal distribution. Cahiers de Biologie Marine, v. 36, p. 133 - 139.

SKOWRONSKI, R. S. P.; GHELLER, P. F.; BROMBERG, S.; DAVID, C. J.; PETTI, M. A. V. \& CORBISIER, T. N. 2009. Distribution of microphytobenthic biomass in Martel Inlet, King George Island (Antarctica). Polar Biology, v. 32, p. $839-851$.

SOUSA, E. C. P. M. 1985. Estudos sobre a variação da produção primária bentônica da região entremarés de praias da Baixada Santista. Tese de doutorado. Instituto Oceanográfico da Universidade de São Paulo, Departamento de Oceanografia Biológica. 179 p. 
SOUSA, E. C. P. M. \& DAVID, C. J. 1996. Variação diária dos pigmentos fotossintetizantes do microfitobentos da Praia de Aparecida, Santos, (2358'48”S - 4619'00”W), São Paulo, Brasil. Revista Brasileira de Biologia, v. 56 (1), p. $147-154$.

SOUSA, E. C. P. M.; TOMMASI, L. R. \& DAVID, C. J. 1998. Microphytobenthic primary production, biomass, nutrients and pollutants of Santos Estuary (24ㅇ, 4620'W). São Paulo, Brazil. Brazilian Archives of Biology and Technology, v. 4 (1), p. 25 - 34.

SUGUIO, K. 1973. Introdução à sedimentologia. São Paulo. Edgard Blücher / EDUSP. $317 \mathrm{p}$.

SUMIDA, P. Y. G.; YOSHINAGA, M. Y.; CIOTTI, A. M. \& GAETA, S. A. 2005. Benthic response to upwelling events off the SE Brazilian coast. Marine Ecology Progress Series, v. 291: p. 35 - 42.

SUNDBÄCK, K. \& PERSON, L. E. 1981. The effect of microbenthic grazing by an amphipod Bathyporeia pilosa, Lindström. Kieler Meeresforschungen Sonderheft, v. 5, p. 573 - 575.

SUNDBÄCK, K. \& GRANÉLLI, W. 1988. Influence of microphytobenthos on the nutrient flux between sediment and water: a laboratory study. Marine Ecology Progress Series, v. 43, p. 63 - 69.

SUNDBÄCK, K. \& JÖNSSON, B. 1988. Microphytobenthic productivity and biomass in sublittoral sediments of a stratiWed bay, southeastern Kattegat. Journal of Experimental Marine Biology and Ecology, v. 122, p. 63 - 81.

TUCHMAN, N. C.; SCHOLLeTT, M. A.; RIER, S. T. \& GEDDES, P. 2006. Differential heterotrophic utilization of organic compounds by diatoms and bacteria under light and dark conditions. Hydrobiologia, v, 561, p. 167 - 77. 
UBERTINI, M.; LEFEBVRE, S.; GANGNERY, A.; GRANGERÉ, K.; LE GENDRE, R. \& ORVAIN, FRANCIS. 2012. Spatial variability of benthic-pelagic coupling in an estuary ecosystem: Consequences for microphytobenthos resuspension phenomenon. PLoS ONE, v. 7 (8), p. 1 - 17.

YOSHINO, K.; MIYASAKA, H.; KAWAMURA, Y.; GENKAI-KATO, M.; OKUDA, N.; HAYAMI, Y.; ITO, SAYAKA; FUKUMORI, K.; SEKIGUCHI, T.; OHNISHI, H.; OHMORI, K \& TAKEOKA, H. 2006. Sand banks contribute to the production of coastal waters by making a habitat for benthic microalgae in the sublittoral zone: food web analyses in Aki-Nada using stable isotopes. Plankton and Benthos Research, v. 1 (3), p. 155 - 163.

ZAR, J. H. 2010. Biostatitical Analysis. 5th edition. New Jersey: Pearson Prentice Hall. 944 p. 